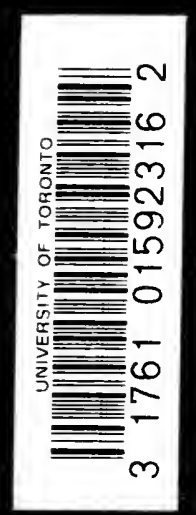

4 



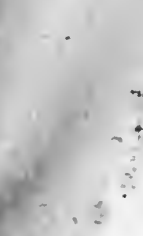




Digitized by the Internet Archive in 2007 with funding from Microsoft Corporation 


\section{1 \\ PROVINCIAL AND LOCAL TAXATION IN CANADA}



STUDIES IN HISTORY, ECONOMICS AND PUBLIC LAW EDITED BY THE FACULTY OF POLITICAL SCIENCE OF COLUMBIA UNIVERSITY

Volume LII]

[Number 1

Whole Number 128

\title{
PROVINCIAL AND LOCAL TAXATION IN CANADA
}

\author{
$\mathbf{B Y}$ \\ SOLOMON VINEBERG, Ph.D. \\ Sometime Garth Fellow in Economics \\ Columbia University
}

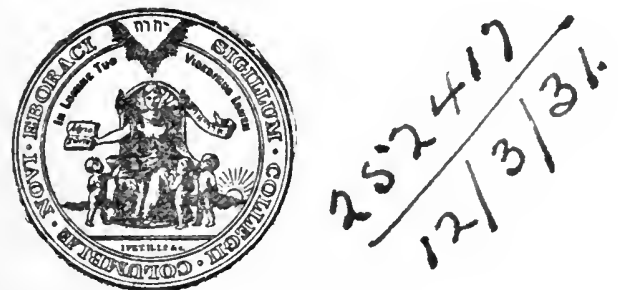

New Work

COLUMBIA UNIVERSITY

LONGMANS, GREEN \& CO., AGENTS

LONDON : P.S. KING \& SON

I9I 2 


\section{COPYRIGHT, 1912}

BY

SOLOMON VINEBERG

$$
\begin{aligned}
& H J \\
& 9351 \\
& V 4
\end{aligned}
$$




\section{PREFACE}

The purpose of this monograph is to present a description of the tax systems of the Canadian Provinces, with an outline of the development of the more prominent features and comments on the working of each. The various Provincial statutes dealing with tax matters have been made the framework, and commission reports and other government publications have been utilized. Outside of these, however, the field is barren of material, a handicap which makes itself evident throughout the study. The chief value of the work lies thus in the fact that it breaks new ground. At a future date the author hopes to be able to give to some of the phases of taxation taken up herein a much fuller treatment than is possible in a monograph of this nature.

The subject was suggested by Professor Seligman, to whom the author is also greatly indebted for much valuable advice. The many courtesies extended by $\mathrm{Mr}$. C. H. Gould, Librarian of McGill University, have made possible a thorough examination of the tax laws, and the Provincial and municipal officials throughout the country have aided greatly by furnishing reports and general information. The author also wishes to express his thanks to Professor $\dot{H}$. R. Seager for his kindness in reading the proof.

New York, April, igr 2.

S. V. 



\section{TABLE OF CONTENTS}

\section{CHAPTER I}

The Growth of the Canadian Constitution

The French Régime $\ldots \ldots \ldots \ldots \ldots \ldots \ldots \ldots \ldots \ldots \ldots \ldots \ldots \ldots \ldots \ldots \ldots$ II

Government by Proclamation $\ldots \ldots \ldots \ldots \ldots \ldots \ldots \ldots \ldots \ldots \ldots \ldots$ in

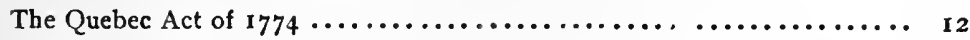

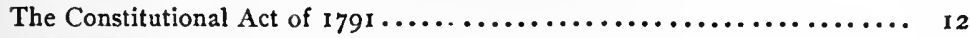

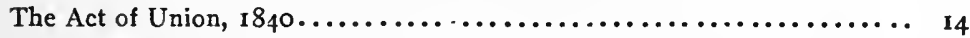

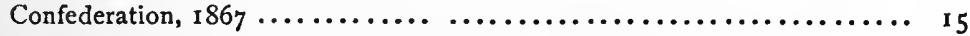

Comparison of the Constitution of Canada with that of the United States... I6

The distribution of the taxing powers $\ldots \ldots \ldots \ldots \ldots \ldots \ldots \ldots \ldots \ldots, 18$

\section{CHAPTER II}

\section{The Development of Municipal. Institutions}

Local government under French rule.................... 22

Local government before the Act of Union $\ldots \ldots \ldots \ldots \ldots \ldots \ldots \ldots \ldots, 23$

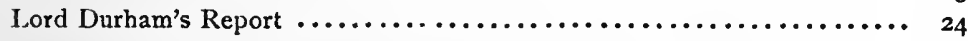

Municipal institutions in Lower and Upper Canada $\because \ldots \ldots \ldots \ldots \ldots \ldots .25$

Municipal institutions in the Maritime Provinces................ 27

Municipal institutions in the western Provinces................. 28

\section{CHAPTER III}

\section{Early Taxation}

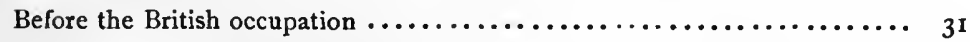

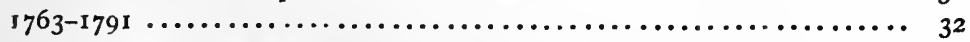

The first general assessment act in Upper Canada............... 32

The first general assessment act in Lower Canada................ 34

Lord Durham on Canada's condition....................... 34

The tax systems under the Union......................... 35

Early taxation in Nova Scotia and New Brunswick $\ldots \ldots \ldots \ldots \ldots \ldots \ldots . . \cdots \cdots$

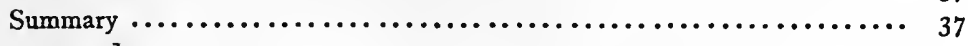


CHAPTER IV

The fallure of the Personal Property tax

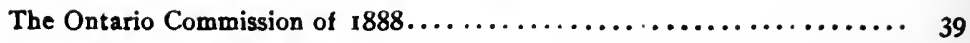

The Ontario Commission of $1900 . . \ldots \ldots \ldots \ldots \ldots \ldots \ldots \ldots \ldots \ldots . \ldots \ldots$

The inequalities of the Ontario system $\ldots \ldots \ldots \ldots \ldots \ldots \ldots \ldots \ldots \ldots, 40$

Recommendations of the Commission of $1900 \ldots \ldots \ldots \ldots \ldots \ldots \ldots \ldots, 43$

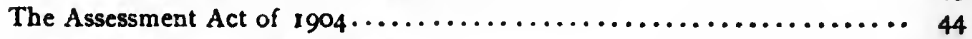

The personal property tax in Manitoba...................... 44

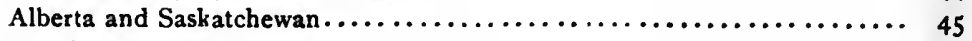

British Columbia................................... 45

Nova Scotia and New Brunswick.... .................... 45

Conclusion $\ldots \ldots \ldots \ldots \ldots \ldots \ldots \ldots \ldots \ldots \ldots \ldots \ldots \ldots \ldots \ldots \ldots,{ }_{46}$

\section{CHAPTER V}

The Business Assessment :

A SUBSTITUTE FOR THE PERSONAL PROPERTY TAX

Business taxes in the Province of Quebec $\ldots \ldots \ldots \ldots \ldots \ldots \ldots \ldots \ldots \ldots, 48$

Business assessments in Manitoba $\ldots \ldots \ldots \ldots \ldots \ldots \ldots \ldots \ldots \ldots \ldots .49$

Business assessments in Saskatchewan and Alberta.............. 50

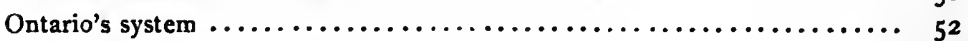

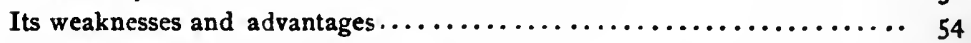

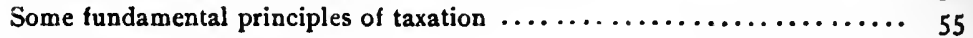

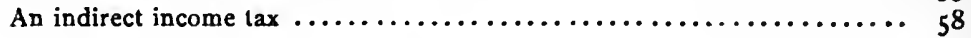

\section{CHAPTER VI}

\section{INCOME TAXes}

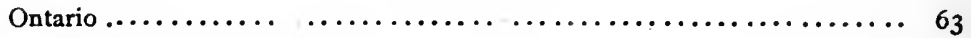

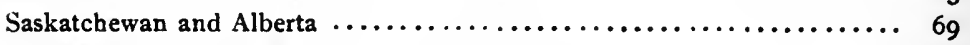

The Maritime Provinces............................

British Columbia................................ 73

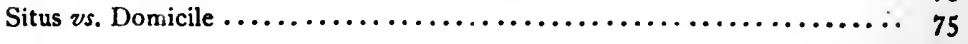

\section{CHAPTER VII}

Taxes on Real Estate:

THE EXEMPTION OF IMPROVEMENTS

British Columbia................................. 78

Alberta and Saskatchewan $\ldots \ldots \ldots \ldots \ldots \ldots \ldots \ldots \ldots \ldots \ldots \ldots \ldots, \mathbf{8}_{3}$

General conclusion $. \ldots \ldots \ldots \ldots \ldots \ldots \ldots \ldots \ldots \ldots \ldots \ldots \ldots \ldots, 88$ 


\section{CHAPTER VIII}

PAGK

Taxes on Real Estate

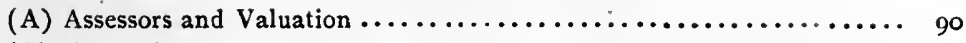

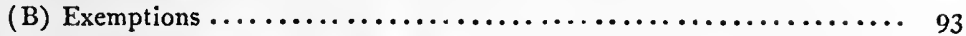

(C) Special Assessments for Local Improvements $\ldots \ldots \ldots \ldots \ldots \ldots \ldots \ldots 96$

(D) Statute Labor and Poll Taxes........................ 103

(E) Taxation of Mortgages........................... 106

\section{CHAPTER IX}

\section{Provincial Taxation:}

\section{CORPORATION TAXES}

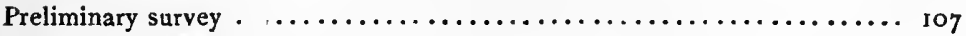

Quebec........................................... I

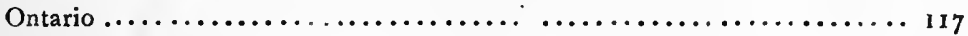

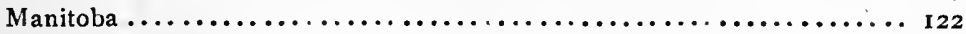

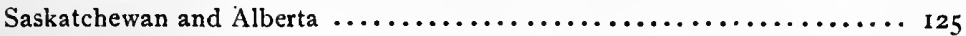

British Columbia................................... 129

New Brunswick.................................... 131

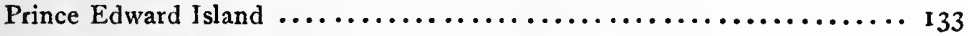

| General conclusion $\ldots \ldots \ldots \ldots \ldots \ldots \ldots \ldots \ldots \ldots \ldots \ldots \ldots \ldots \ldots$. 33

\section{CHAPTER X}

\section{Provincial Taxation :}

\section{SUCCESSION DUTIES}

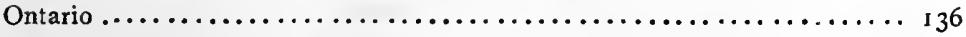

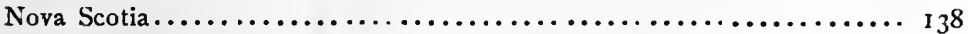

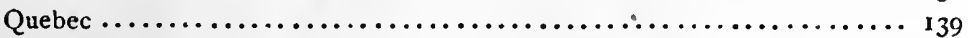

New Brunswick................................. I4I

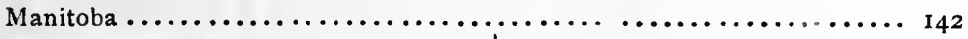

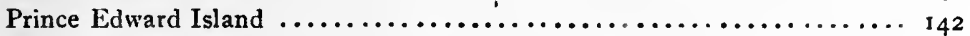

British Columbia.................................... I43

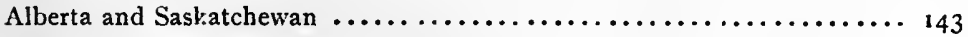

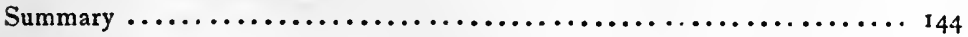

Probate fees...................................... 144

Situs vs. Domicile ................................... I46

Legal decisions..................................... 149 


\section{CHAPTER XI}

The Separation of Sources of Revenue

The result of historical development $\ldots \ldots \ldots \ldots \ldots \ldots \ldots \ldots \ldots \ldots \ldots, 153$

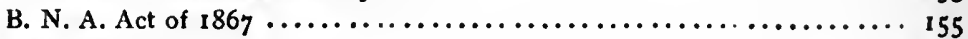

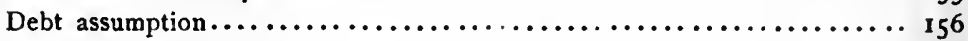

Annual subsidies.................................. $1_{5} 8$

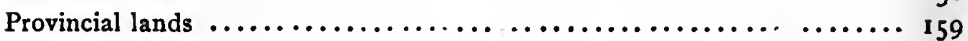

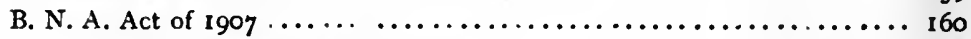

The dangers of the granting of subsidies...................... 162

Provincial views of the grants........................... 163

The division of the field of taxation in the Provinces $\ldots \ldots \ldots \ldots \ldots \ldots . \cdots 165$

Double taxation.................................... $16_{5}$

\section{CHAPTER XII}

Conchusion........................................ 167

\section{APPENDIX}

Statements of Provincial Revenue $\ldots \ldots \ldots \ldots \ldots \ldots \ldots \ldots \ldots \ldots . \ldots 169$ 


\section{CHAPTER I}

\section{The Growth of the Canadian Constitution}

THE development of the systems of taxation of the Canadian Provinces is so bound up with the political growth of the country that an examination of the latter becomes necessary before passing on to the subject matter of this monograph. More than a mere outline, however, will not be possible.

Even the smallest degree of self-government was unknown in Canada under French rule. In $16 \% 3$, when the charter of the "Hundred Associates" was abandoned, the country became a royal province under the rule of the king, who administered the law through a governor and an intendant. These officials controlled all the affairs of the country, the people having a voice only in church matters of minor importance. Between the years 1647 and 1663 , efforts were made to institute a small degree of local self-government, ${ }^{\mathrm{x}}$ but even this was forced to give way before the jealousy of the Crown.

With these facts before us, we can readily see how the inexperience of the French-Canadians in political affairs prevented the British from establishing parliamentary institutions until thirty years after the conquest. The country was under military rule for three years, i760I763. Upon the cession of Canada to the English in I763, a royal proclamation provided for the government 
of the Province by a governor and council, both appointed. It was not until eleven years later that the British Parliament took a hand in Canadian affairs. In 1774 it passed the Quebec Act granting important concessions to the French-Canadians, but not changing the form of government. It was these concessions as well as the attitude of the priests toward the Puritans of New England, which caused the refusal of the terms of the American Congress by the French. ${ }^{x}$

The Quebec Act remained in force until I 79r when it was amended as far as it concerned the form of government. The whole Province was divided into Upper and Lower Canada and provision was made for a popular assembly in each division. This is Canada's first liberal constitution. $^{2}$ The year I 784 had seen the influx of thousands of Loyalists from the new republic to the south. These at once joined the older British settlers in their clamors for parliamentary government and other English institutions, with the result that a partial separation between the French and the English was effected and English civil law was instituted in the upper Province, leaving French civil law, as provided for by the Quebec Act, in the lower. In addition to the elective assembly established in each Province, provision was made for a governor and a legislative council, the members of which were to be appointed by the king for life. The regulation of navigation and commerce, with the accompanying right of levying duties, was still retained by the Imperial Government, subject, however, to the

1 Vide Bradshaw, Self-Government in Canada, p. 30.

2 The Maritime Provinces had already received constitutions, Nova Scotia in 1758, Prince Edward Island, 1773, and New Brunswick in 1784. Vide Todd, Parliamentary Government in the British Colonies, p. 73 . 
Declaratory Act of 1778 , by which England had renounced the right of taxing her dependencies for revenue purposes and retained control of certain sources with the proviso that the returns were to be expended where collected.

The political history of Canada under the Act of I79I is an account of the struggle by the assemblies of both Provinces for complete self-government through the control of the revenues. In the early days, Britain looked upon Canada as a military colony and met deficits in the local budgets by drawing on the military chest. Lord Dorchester, in opening the second session of the Parliament of Lower Canada in I793, spoke of the necessity of considering means of increasing the Provincial revenue, and went on to say that he was sure that "Great Britain would continue generously to furnish the surplus necessary for the prosperity of the colony." "In 1810 , the Assembly of Lower Canada sent an address to the King in which they stated that the prosperous condition of the country would enable them to take charge of the civil expenditure of the Province, until that time, met, in large part, by His Majesty. ${ }^{2}$ Although many in England thought they saw an ulterior motive, namely, the control of the revenue, in this address, the supplying of deficits by Britain was discontinued after $1812 .{ }^{3}$ The Crown revenues, derived from duties imposed under an Imperial Act of 1774 and from certain casual and territorial revenues, were insufficient to meet the civil expenses of the Government, and the governor, with the advice of the executive council, used Provincial funds,

1 Bibaud, Histoire du Canada, vol. ii, r22.

Ibid., pp. 147 et seq.

' Kingsford, History of Canada, vol, ix, p. 91. 
raised from duties established by the Legislature, to meet the deficits. In 1819 a sum of $f_{120,000}$ was due the Province from the Government. ${ }^{x}$

The report of a committee of the Imperial Parliament in 1828 recommended that the House of Assembly be given control of all Provincial revenues in return for the voting of a Civil List. This advice was partially followed when, four years later, the Home Government gave Canada full control of the customs revenues. ${ }^{2}$ In 1813 , a large part of the Crown revenues was surrendered to the Assembly of Upper Canada where the surplus from sources under the Royal control had given the Government a large degree of independence. ${ }^{3}$ The struggle for full responsible government continued in both Provinces, culminating with the rebellion of $1837-8$, the report of Lord Durham and the Act of Union.

Lord Durham declared himself in favor of the "full establishment of responsible government," which, he declared could be made secure only by a union of the two Provinces. ${ }^{4}$ The union was effected by the Act of 1840 which made provision for the surrender to the united Legislature of all Provincial revenues, after the payment of $£_{75}, 000$ for a Civil List and other expenses. ${ }^{5}$ It was not, however, until $\mathrm{I} 846$, that the Assembly gained complete control of all the revenues, thus ending the struggle for responsible government. The Act of Union, itself a result of Durham's investigation, marks an epoch in Britain's policy toward her North American colonies, for,

1 Bradshaw, Self-Government in Canada, p. 64.

Ibid., pp. 77-79.

Ibid., pp. Ir8-9.

'Durham's Report (Dutton \& Co., I902), p. 225.

Bradshaw, op. cit., p. 354 . 
from that date, every possible measure has been taken to enlarge the sphere of self-government. ${ }^{x}$

The period from 1840 to 1864 is marked by various measures tending to more popular government. The year 1854 is made prominent by the abolition of the seigniorial tenure, a relic of French-Canadian feudalism, and by the disposal of the Clergy Reserves question, thus avoiding an established church in Canada. A dispute as to the distribution of representatives, which had begun soon after the Union, resulted in a deadlock in I864, and it was seen that some new provision for the government of the country was necessary.

Colonial statesmen were now forced to consider steps toward a union of all Britain's North American Provinces under one central government, a move which had been suggested as early as $1814 .^{2}$ At a conference of the representatives of the five Provinces ${ }^{3}$ at Quebec in I864, there was drawn up a series of seventy-two resolutions, which, with slight changes, became the British North America Act of 1867 . This Act divided the Province of Canada into Ontario and Quebec and united these with New Brunswick and Nova Scotia to form a federation, to be known as the Dominion of Canada, with its central government at Ottawa. The vast areas of the northwest territories were granted to the Federal Government in 1868, and Manitoba and British Columbia entered the Union as Provinces in 1870 and 1871, respectively. Prince Edward Island joined the Dominion in 1873. All territory outside of the seven Provinces remained unorganized until 1905, when the

${ }^{1}$ Bourinot, Manual of Constitutional History of Canada, p. 28.

Vide Bradshaw, op. cit., pp. 18-19.

3 Canada (Upper and Lower), New Brunswick, Nova Scotia, Prince Edward Island and Newfoundland. 
increase in population justified the Central Government in forming two western Provinces, Saskatchewan and Alberta. The Dominion of Canada now consists of the above nine Provinces and the more sparsely settled districts to the north, comprising in all an area somewhat larger than that of the United States.

The organs of government are the Governor-General, appointed by the Crown for four years, the Senate, appointed by the Governor-General for life, and the House of Commons, elected for a maximum term of five years. The system is modeled largely on that of Great Britain in that there is a responsible Cabinet working on lines similar to that of the mother country. Thus the Governor-General bears the same relation to the Cabinet and the two Houses as the King does to those of England; the real head of the Government is the Premier. The Provincial governments are also models of the British system. Each Province has a Lieutenant-Governor, appointed by the Federal Government, and a legislative body consisting (with the exception of Quebec and Nova Scotia) of only one house, the Assembly.

A comparison of the Canadian system of government with that of the United States reveals a number of points of contrast, one of the prominent differences being in regard to the seat of sovereignty. In the United States, the supreme power rests with the citizens, while in Canada the will of the people and Parliament of Great Britain is supreme. This authority is seen, however, only in the appointment of the Governor-General by the Crown; in the application of certain Imperial Acts to Canada; ${ }^{x}$ and in the limitations placed upon the right of

Such as patent and copyright, merchant and shipping, extradition and other acts of a general character. Vide Munro, Constitution of Canada, p. 268. 
the Dominion to alter its constitution. The remaining differences between the governmental systems are chiefly respecting the distribution of powers between the central and local governments. The aim of the fathers of the Canadian Union was the establishment of a constitution which would secure greater centralization and greater uniformity than that which existed in the United States. $^{2}$ This they have accomplished by the following provisions :

I. The "residual powers" of government, which in the United States rest with the several states, are in Canada expressly retained for the central authority, thus throwing the burden of proof in case of dispute upon the Provinces."

II. Concurrent powers of legislation can exist over no subject matter except agriculture and immigration. Should there be conflict even on these matters the authority of the Central Government is supreme." "By the construction put by the Supreme Court of the United States upon the Constitution, concurrent jurisdiction has been found to exist in relation to several subjects; and legislation by the states has been decreed to be 'intra vires' in many cases, until Congress legislated on the same subject." 5

III. The Lieutenant-Governor of each Province is appointed by the Governor-General, that is, by the Dominion Cabinet. $\mathrm{He}$ does not represent the British Crown; on the contrary, he

1 Changes have been made by the British Parliament upon the petition of the Canadian Government. Cf. infra, chapter on "Separation of Sources."

2 Vide Debates on Confederation, Quebec, 1865, p. 33.

B B. N. A. Act, article 9I; also Lefroy, The Law of the Legislative Power in Canada, pp. 347 and 7 ro.

4 B. N. A. Act, article 95 ; vide also Lefroy, op. cit., p. 347, prop. 28.

${ }^{5} 3$ S. C. R., 547 , in ii Cartwright, Cases on the B. N. A. Act of 1867 , pp. $43-4$. 
is a representative of the Dominion Government to which he is directly responsible. ${ }^{2}$

IV. The Federal Government appoints, for "good behavior," all the superior, district and county court judges throughout the Dominion. ${ }^{2}$

V. The Dominion Executive has the power of vetoing Provincial legislation. This right has seldom been exercised, and only when a Legislature clearly has exceeded its jurisdiction. In cases where the competency of the local government to pass an act is doubtful, the question is left to the courts, as is the practice in the United States.

VI. In Canada, the Central Government has jurisdiction over criminal law and the law of marriage and divorce (except the solemnization of marriage within a Province)."

In the distribution of the taxing powers, the chief point of contrast is the absence of constitutional limitations upon the Central and local Governments within their respective jurisdictions. American economists and officials have come to a point where they are forced to recognize that the much-needed reform in state taxation cannot be effected until the constitutional restrictions have been removed. ${ }^{5}$ The British North America Act has four provisions dealing directly with the taxing power. Under article 9I, Parliament is authorized to legislate upon:

1 Munro, Constitution of Canada, p. 80; also ibid., pp. 262-3, and 3 S. C. R., 575, in i Cartwright, 488.

'B. N. A. Act, article 96. Judges of Courts of Probate in N. B. and N. S. are exceptions.

${ }^{3}$ Munro, op. cit., pp. 260 et seq.; cf. also Lefroy, op. cit., pp. 185 et seq.

4 B. N. A. Act, article 92 (12) and article 91 (26 and 27).

'Vide article by Prof. Loeb in Proceedings of First National Conference (Columbus, O., 1907) on State and Local Taxation, p. 75, and also "Resolutions," p. xviii. 
(a) The Regulation of Trade and Commerce.

(b) The Raising of Money by any mode or system of Taxation.

Article 92 grants to the Legislatures exclusive authority in respect to:

(c) Direct Taxation within the Province in order to the raising of a Revenue for Provincial purposes.

(b) Shop, Saloon, Tavern, Auctioneer, and other Licenses, in order to the raising of a Revenue for Provincial, Local or Municipal purposes.

By the first of these provisions the Dominion was granted the exclusive right to levy and collect customs and excise duties and the Provinces were deprived of their chief source of revenue. In return for this loss, the latter were relieved of their debts, and arrangements were made by which they receive annual subsidies, the amount of which is based on a specific sum and a rate per capita. ${ }^{x}$

There appears to be a conflict between the second and third of the above provisions. To obviate this the English Privy Council has decided that direct taxation within the Province to raise revenue for a Provincial purpose lies wholly within the jurisdiction of the Provincial Legislature. ${ }^{2}$ Referring to subsection 3 of Article 91, their Lordships said :

Though the description is sufficiently large and general to include direct taxation within the Province in order to the rais-

${ }^{1}$ B. N. A. Act, articles III to 120 , incl. For details, vide infra, chapter xi.

2 Citizens Ins. Co. vs. Parsons, 7 A. C. 109, in i Cartr., p. 265. Followed in Lambe $v$ s. Bank of Toronto, 12 A C. 575, in iv Cartr., 7. Vide also Clement, The Law of the Canadian Constitution, p. 377. 
ing of a revenue for Provincial purposes, ... it obviously could not have been intended that ... the general power should over-ride the particular.

The limitation placed upon the power of the Dominion to levy direct taxes is therefore expressed in the words "within the Province" and "for Provincial purposes."

It has also been decided" that a Provincial tax on banks is intra vires and not in conflict with the sole right of the Dominion in regard to bank legislation. Until a very recent date various courts ${ }^{2}$ in the Dominion have held that Provincial taxation levied on the income of Federal officials is ultra vires, since it interferes with the power to fix the salaries of such officials. These decisions have been reversed in the case of Abbott vs. City of St. John ${ }^{3}$ by the Supreme Court of Canada, following a decision of the Judicial Committee of the English Privy Council in an Australian case. ${ }^{4}$ At present, an official of the Dominion Government may be taxed on his income by the municipality in which he resides.

In the case of Severn vs. the Queen ${ }^{5}$ it was held that the imposition by Ontario of a license tax on brewers was an interference with the "paramount authority of the Dominion Parliament in matters of trade and commerce and indirect taxation." This decision has been overturned by the Privy Council in the Brewers and Malters Association vs. Attorney-General for Ontario, ${ }^{6}$

${ }^{1}$ Lambe vs. Bank of Toronto, I2 A C. 575, in iv Cartr., 7.

${ }^{2}$ Leprohon vs. City of Ottawa, 2 App. Rep. (Ont.), 522, in i Cartr., 592 ; ex parte Owen, 20 N. B. R., 483, and others.

${ }^{3} 40$ S. C. R., 597 (Oct. 1908).

4 Webb vs. Outrim, 1907 A. C. 8 r.

${ }^{5} 2$ Can. S. C. 74, in i Cartr., 4r4; vide also Doutre, Constitution of Canada, p. 125.

${ }^{6} \Upsilon 897$ A. C. 231. 
when their Lordships held that a license fee upon brewers and distillers to sell wholesale within the Province was direct taxation within the meaning of subsection 2 of Article 92. In this and other cases, ${ }^{x}$ the Privy Council, in deciding whether or not a tax is direct, follow Mill's definition, ${ }^{2}$ and attempt to ascertain the intention of the Legislature.

The decision rendered in Dow ws. Black ${ }^{3}$ declared that the imposition of direct taxation by a Provincial government need not be general throughout the Province, but that power is given by the Act of Confederation to "enable the Provincial Legislature ... to impose direct taxation for a local purpose upon a particular locality within the Province. This includes the right of delegation of such authority to any local jurisdiction within the Province."

${ }^{1}$ 1o A. C. I4I, in iii Cartr., 190; 12 A. C. 575 , in iv Cartr., 7.

2 Mill, Prin. of Pol. Econ. (ed. Laughlin, 1888), p. 550: "A direct $\operatorname{tax}$ is one which is demanded from the very persons who, it is intended, or desired, should pay it."

${ }^{3}$ L. R., 6 P. C. 272 , in i Cartr., 95. 


\section{CHAPTER II}

The Development of Municipal Institutions ${ }^{x}$

CANADA owes as little to the French Régime for its municipal institutions as for its political system. Frontenac attempted to introduce a small degree of local selfgovernment in 1663 , when he provided for the election of a board of aldermen in the city of Quebec. It was his intention to have this board meet semi-annually to consider matters of public welfare, but a rebuke from Colbert stopped all growth in this direction. The aldermen resigned two months after the election, and, soon after, the syndic d'habitation appeared. This official had charge of certain local affairs and represented the community in its dealings with the governor. There are records of the election of syndics in Quebec, Montreal and Three Rivers. Here again, however, the jealousy of the Home Government blocked development, and Colbert instructed Frontenac gradually to suppress the office.

The Intendant, who was at the head of the civil administration throughout the colony, conducted local affairs in person, assisted by the grand voyer. The latter official was an inspector of highways whose special duty it was to oversee roads, bridges and similar matters.

1 Much of the description of the old régime is taken from "Municipal Institutions in Canada," by R. S. Weir, in Hopkins' Encyclopedia of Canada, v, 452. 
This office is found in the legislation of $179^{1}$ and was not abolished until I 841 . $^{2}$

In I722 the whole of New France was divided into eighty-four parishes. But these were primarily ecclesiastical parishes and many had existed before that date. Many of these in later times formed the limits of the civil parishes.

General Murray, the first Governor of Canada under British rule, administered the local affairs of the colony with the assistance of an executive council composed of the local governors of Montreal and Three Rivers, the Chief Justice, the Surveyor of Customs and eight leading residents. This council performed for the towns the duties now discharged by the local councils. The Legislative Council of twenty-three members, appointed under the Quebec Act of I774, also enacted municipal ordinances. The assemblies of the two Provinces into which Canada was divided in I79I continued to oversee local affairs, but the magistrates were entrusted with the administering of the legislation of these bodies. Toward the end of the year $1827^{3}$ citizens of Quebec and Montreal held meetings to urge the Legislature to grant them charters of incorporation by which they might carry on the city government under a mayor and aldermen. They wished to free themselves from the domination of magistrates appointed by the Crown. It was not, however, before 1832 , that these cities were incorporated and then only by temporary charters for four years. Toronto and five or six other towns of Upper Canada also received acts of incorporation from the Legislature during this decade, but, outside of these, local affairs were still administered

136 Geo. III, c. 9.

${ }^{2} 4$ Victoria, c. 4 .

Kingsford, History of Canada, ix, 329. 
by the justices in quarter session. Turnpike trusts and bridge companies were formed during about the same period and some measure of improvement of communication was thus obtained.

It was not until after the rebellion and the report of Lord Durham that general provision was made for municipal self-government. This report gave the want of municipal institutions as one of the "main causes of failure of representative government and of the bad administration of the country." There was a complete absence of a regular administration in the rural districts of the lower Province, which Durham attributed to the character of the French population, which had been made dependent on the central authority for its government. The only institution in Lower Canada having the nature of local self-government was the fabrique, by which provision was made for the repair of Catholic churches. The need of local self-government was seen by contrasting the condition of the Eastern Townships with that of Vermont, where the municipal system had received considerable development.

"The inhabitants of Lower Canada," said Durham, "were unhappily initiated into self-government at exactly the wrong end, and those who were not trusted with the management of a parish were enabled by their votes to influence the destinies of the state." $\mathrm{He}$ also referred to the disgraceful state of the streets and the absence of lighting in Quebec and Montreal, whose charters had not been renewed in $1836 .^{2}$ Following his recommendation, ${ }^{3}$ the Special Council, which had been appointed after the suspension of the Constitution, upon the outbreak of re-

${ }^{1}$ Durham's Report (Dutton, 1902), p. 79.

Idem, p. 8r.

${ }^{3}$ Idem, p. $2 \mathrm{II}$. 
bellion in Lower Canada, passed, in $1840,{ }^{x}$ an ordinance providing for the internal government of the Province by the establishment of local institutions under the control of the central authority. This ordinance did not apply to Quebec and Montreal, provision for the government of which was made by the granting of new charters. The Province was divided into districts, each of which was a body corporate to be governed by an appointed warden and elected councillors.

The majority of the inhabitants of the Province viewed with suspicion this granting of local self-government and soon there arose a party called Les Eteignoirs (extinguishers), whose aim was to render the act inoperative by electing councillors pledged to do nothing to put it in operation. Their policy killed the measure, ${ }^{2}$ and it was not until five years later, ${ }^{3}$ when more liberal provisions were made, that Lower Canada had any system of municipal government. Every township and parish was made a municipal corporation represented by an elected council and mayor. Even this measure, liberal as it was, met with the opposition of the French-Canadian members of the Legislature, who felt that municipal institutions would render local taxation a necessity. ${ }^{4}$

The localities of Upper Canada had been forced to shift for themselves to a greater extent than those of the lower Province where the Government revenue was larger. Here Lord Durham, however, also called attention to the bad state of the roads and to the need of

${ }_{4}$ Victoria, c. 4 .

Weir, Municipal Institutions in the Province of Quebec, p. 52, in Toronto Univ. Studies.

8 Victoria, c. 40 (1845).

- Dent, Canada Since $1841, \mathrm{i}, 147$. 
other local improvements." The limited funds which had been voted by the Assembly for these purposes had been spent in the interest of the more settled districts in order to strengthen the influence of the members in their constituencies. The want of good municipal institutions in this Province was so great that it received the attention of Parliament immediately after the union. In I $841,{ }^{2}$ the District Municipal Act gave to the inhabitants of each district such corporate powers as were "absolutely necessary." Each district was to have a council composed of a warden, appointed by the governor, and one or two other councillors for each township in the district, according to population, to be elected annually. The old powers of the justices of the peace in quarter sessions were, by this act, transferred to the newly created district councils. ${ }^{3}$

An amending act ${ }^{4}$ later permitted the councillors to elect their own wardens, and, in $1849,{ }^{5}$ the Province received its first general municipal act. The Baldwin Act, as this measure is called, made provision "by one general law, for the erection of municipal corporations ... in and for the several counties, cities, towns, townships and villages in Upper Canada." The system introduced by this act has remained, with various changes in details, to the present, ${ }^{6}$ and has served as a model for municipal organization in Manitoba.

In 1847,7 parish and township municipalities were

1 Report, pp. I3I-8.

${ }^{2} 4$ and 5 Victoria, c. 10.

3 Vide Shortt, Municipal Government in Ontario, pp. 24-5, in Toronto Univ. Studies.

49 Victoria, c. 40 ( 1846$)$. 5 I2 Victoria, c. 80.

6 ide 3 Edward VII, c. 19 and amendments.

Io and II Victoria, c. 7. 
abolished in Lower Canada and county municipalities with elective councillors and mayors were substituted. Provisions for the incorporation of towns and villages were also made. The municipal system of this Province was again amended by the Lower Canada Municipal and Roads Act in $1855 .^{\circ}$ This act is the basis of the municipal system at present in operation in the Province of Quebec. Here the Legislature has provided a general act for the incorporation of cities and towns, ${ }^{2}$ but most of these municipalities have obtained their charters by special acts. The municipal code applies to all the territory of the Province except the cities and towns incorporated by special statute and divides this territory into county municipalities which may include city, town or village municipalities. The county council is composed of the mayors in office in all the local municipalities of the county.

Municipal organization came late in the Maritime Provinces. ${ }^{3}$ It was not until the year 1879 that Nova Scotia passed its compulsory County and Township Act to provide for local self-government, ${ }^{4}$ and there were no general provisions for the incorporation of towns until I888. Before this, however, several towns had been incorporated by special acts. The Province of New Rrunswick passed a permissive County Councils Act in $185^{2}$ and a compulsory act in 1877 . The city of St. John received its first charter as early as 1785 , and, between the years 1848 and 1888 , many towns were incorporated

1 I 8 Victoria, c. 100.

40 Victoria, c. 29 (1876); 3 Edward VII, c. 38 (I903).

${ }^{3}$ Vide Murray, Local Government in the Maritime Provinces, in Toronto Univ. Studies, History and Econ., vol. ii.

- Permissive acts passed in $1855-6$. 
under special statutes. The Towns Incorporation Act was passed in 1890 .

In Prince Edward Island, Charlottetown and Summerside are the only incorporated towns, and were so constituted by special acts of the Legislature. The Provincial Goverment levies land, income and road taxes on the whole Province, the above two cities excepted. The land-tax act of $1894^{\prime}$ placed a specific rate of from one to six cents per acre on land. Three years later $^{2}$ this was changed to a percentage tax of one-fifth of one per cent on the value of the land, to be determined by a "solemn declaration" of the owner. The income tax does not apply to farms subject to the land tax, nor to wages under $\$ 350$; the rate is now one and one-half per cent. $^{3}$ For the maintenance of the roads, ${ }^{4}$ a poll tax of $\$ 1.00$ on men residing in the road districts and a tax on horses are collected. The revenue derived by the Provincial Government from this local taxation is expended in local improvements and in support of education.

The Province of Alberta has an act ${ }^{5}$ providing for the incorporation of villages, but has effected the organization of its cities and towns by special legislation. Since I908, ${ }^{6}$ Saskatchewan has general acts for the incorporation of cities, towns and villages. ${ }^{7}$ Both of these Provinces have inherited the Local Improvement Districts from the Ordinances of the Northwest Territories. ${ }^{8}$

'57 Victoria, c. I.

250 Victoria, c. 3.

3 Vide infra, chapter on "Income Taxes," pp. 72-3.

42 Edward VII, c. 2.

s 1907 , chap. 10.

I I908, chaps. I6, I7 and I8.

'Amendment of N. W. T. Ordinance, I90I, c. 25.

- Ordinances of I903, session 2, chap. 24. 
These are loose organizations in districts lying outside of the city, town or village municipalities, which have been granted a small degree of self-government, chiefly for the purpose of levying taxes to effect necessary improvements. In Alberta, ${ }^{x}$ the councils of these districts are authorized to levy from one and three-fourth cents to five cents per acre on lands within their respective jurisdictions, while, in Saskatchewan, ${ }^{2}$ the minimum rate is one and one-fourth cents per acre. Both Provinces also levy a tax on land for educational purposes. In the former $^{3}$ the rate is one and three-fourth cents per acre and is levied on all lands lying outside of organized school districts, while the latter ${ }^{4}$ levies one cent per acre on all land not lying within a town or village school district.

The cities and towns of British Columbia have been incorporated by special charters. This Province, in I906,5 made a move in the direction of uniformity by applying the Municipal Clauses Act, which had been applicable only to smaller municipalities, to all municipal organizations in so far as it is in accordance with their acts of incorporation. There are now about fifty municipalities in British Columbia, but by far the greater extent of territory lies outside of their jurisdiction. The Provincial Legislature levies taxes on the lands in these outlying districts, and expends the revenue thus obtained in public improvements, such as roads and bridges, in assisting and maintaining schools and in the administration of justice. The rates ${ }^{6}$ on such lands are four per cent for wild,

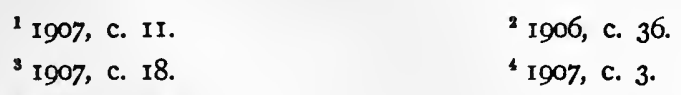

66 Edward VII, c. 32.

6 5 Edward VII, c. 50; 7 Edward VII, c. 43, and ro Edward VII, c. 47 . 
one per cent and two per cent on coal and two per cent on timber lands, and one-half of one per cent on all other realty. The Province also taxes all personal property and income, including that within the municipalities, which are restricted to the taxation of real estate.

1 Vide infra, chapter on "Income Tax," pp. 73 et seq., and chap. iv, p. 45 . 


\section{CHAPTER III}

\section{EARLy TAXation}

UNDER the French Régime there was no general system of taxation. Temporary and local assessments were, in a few instances, levied for special purposes, but even these were imposed by the King himself. About the year I7I6, Louis XIV imposed a tax of 6000 livres on the inhabitants of Montreal to defray part of the cost of fortifying that city. ${ }^{\mathrm{I}}$ In 1742 , Louis $\mathrm{XV}$ issued an order reminding the governor and intendant that they had no power to impose taxes. "That is a sovereign right," said the order, "which His Majesty delegates to none; the inhabitants of the colonies are not even permitted to tax themselves without authorization." 2

A revenue of about 100,000 lives was derived in normal years from the customs. ${ }^{3}$ These duties consisted of a tax of Io per cent on liquors and tobacco and 3 per cent on general merchandise imported or exported.4 A large revenue was also derived from the fur trade, a considerable royalty being exacted on all pelts taken. ${ }^{5}$

All roads and bridges were under the supervision of the grand voyer, upon whose report that work was re-

${ }^{1}$ Garneau, Histoire du Canada, 4me edition, I882, i, $18 \mathrm{I}$.

2 Petit, Gouvernement des colonies françaises, in Garneau, op. cit., I8I.

${ }^{3}$ Garneau, op. cit., ii, 160.

Ibid., and R. S. Weir, Administration of the Old Régime in Canada, p. 74 .

${ }^{5}$ Weir, loc. cit. 
quired on an old road or that a new one was needed, the intendant issued an ordinance compelling all residents in the district affected to carry out the work desired. It was the corve transplanted from France. ${ }^{3}$

These were the conditions in 1760 , when the English came into possession, and very little change took place until after I79I. The council formed by General Murray in I763 had no power to levy taxes, ${ }^{2}$ and the Quebec Act (1774) forbade the laying of any new taxes by the Legislative Council, except in so far as the inhabitants of any town or district be "authorized to assess, levy or apply, within the said town or district," taxes or duties for purely local purposes. That even this limited power was not taken advantage of was due to the lack of a representative form of government ${ }^{3}$ and to the opposition of the French-Canadians. ${ }^{4}$ In 1777 , we find an ordinance providing for the repair and maintenance of roads and bridges under the direction of the grand voyer. All lands used in the construction of roads were paid for by the proprietors of the parish, who were also compelled to perform statute labor. It is not until the period following the establishment of a popular assembly in I79r that we find any general provisions for assessment for local purposes.

Upper Canada passed the first assessment act in $1793^{5}$ This provided for the division of all householders into eight groups, according to the value of their property, with a lump-sum tax for each individual within the groups. All property owners whose holdings did not

1 Vide Weir, op. cit., pp. 76-7.

2 Garneau, op. cit., ii, 397.

${ }^{3}$ Canadian Archives, Constitutional Documents, foot-note, p. 502.

- Idem., p. 513, and pp. 516 et seq.

${ }^{5} 33$ George III, c. 3. 
exceed $t_{50}$ in value were exempt and the highest class was made up of those owning property to the value of $\mathfrak{£}_{400}$ or over. The maximum rate was 2 s. $6 \mathrm{~d}$. per $£_{50}$. Much was left to the discretion of the assessors, since the kinds of property taxable were not specified. In the same year, ${ }^{x}$ the office of grand voyer was established in the upper Province, and it was enacted that the justices of the peace in quarter sessions should act as commissioners of highways, with overseers in charge of the actual work.

The roads and bridges, however, continued to be built chiefly by statute labor, which, after $1798,{ }^{2}$ was proportioned to the amount of assessment. Five years later, ${ }^{3}$ a more equitable system of assessment was introduced by the abolition of the classification of 1793 and by the definition of taxable property. This was declared to be both real and personal, the ratable objects in the latter class being specified with a fixed valuation for each. The rate of taxation was determined by the justices of the peace according to the amount of revenue required.

Various amending statutes were passed by the Assembly in its efforts to arrive at a fair valuation of property. That of the year $1819^{4}$ will serve to indicate the method followed. Specific values per acre were given to arable or pasture lands, uncultivated lands and town lots; the values of houses varied according to whether they were built of square timber, boards, brick or stone, and according to the number of stories and the number of fireplaces; specific values were given for mills, shops, store houses, horses, cattle and carriages kept for pleasure. The maximum rate was $\mathrm{I} d$. on the pound. This

13 George III, c. 4.

${ }^{3} 43$ George III, c. 12.
${ }^{2} 38$ George III, c. 7.

59 George III, c. 7. 
system prevailed until the end of the forties, when the Parliament of Canada provided for uniform municipal organization.

The first assessment act in Lower Canada was not passed until I796," when the French system was continued for the whole Province except Quebec and Montreal, where statute labor and composition money provided for by the law were supplemented by an annual assessment upon the occupiers of lands and houses in proportion to the value thereof. The justices of the peace in quarter sessions were to fix the rate of assessment. The persistent opposition of the French-Canadians to direct taxation in any form was so successful that just previous to the union of $\mathrm{I} 84 \mathrm{I}$ we find the crude system of the Old Régime still holding sway." Lord Durham, in his report following the troubles of $1837-8$, said $:^{3}$

There is hardly the semblance of direct taxation in Lower Canada for general or local purposes. This immunity from taxation has been sometimes spoken of as a great privilege of the people of Lower Canada, and a great proof of the justice and benevolence of their government. . . . A people can hardly be congratulated on having had at little cost a rude and imperfect administration of justice, hardly the semblance of police, no public provision for education, no lighting and bad pavements in the cities, and means of communication so imperfect that the loss of time and the wear and tear caused in taking any article to market may probably be estimated at ten times the expense of good roads.

From this it may be seen that the opponents of a sys-

136 George III, c. 9.

${ }^{2}$ Vide Can. Archives, Documents on Constitutional History, pp. $5^{1} 3$ and 516 .

3 Edition of rgo2 (Dutton \& Co.), p. ro2. 
tem of taxation could not have founded their arguments upon the needlessness of any such scheme. Opposition was based chiefly on the claim that the Province was too impoverished to admit of an increased burden.

The collection of the customs duties by the lower Province and the retaining of the lion's share for its own treasury enabled the Legislature to undertake many local works which in later times would have been left to the municipalities. In Upper Canada, because of a deficiency in revenue brought about by careless expenditure as well as by the smallness of its share of the customs duties, the Government had, "fortunately for itself, been compelled to establish a system of local assessments and to leave local works, in a great measure, to the energy and means of the localities themselves." Favoritism had played such a large part in both Provinces that many localities were left to shift for themselves while those with greater political influence enjoyed extensive local works constructed at the expense of the Provincial Governments.

Lower Canada's first effective municipal act ${ }^{2}$ authorized the council of each local corporation to assess the sum required for any purpose upon the value of immovable property, the rate not to exceed $3 \mathrm{~d}$. in the pound per annum. Thus the lower Province restricted its localities to a tax on real property, which system, supplemented later, in certain instances, by business taxes, has remained to the present time.

Under the District Municipal Act of $\mathrm{I}_{84} \mathrm{I}^{3}$ the local councils of Upper Canada were empowered to raise money by tolls or by assessments on real or personal

${ }^{1}$ Durham's Report, p. 109.

${ }^{2} 8$ Victoria, c. 40 (1845).

${ }^{3} 4$ and 5 Victoria, c. Io. 
property or both. In other words, the system of taxation was to follow the assessment laws previously in force, the chief change effected by the act being the transfer of the tax powers of the magistrates to the newly created district councils. An assessment act was passed in $185^{\circ}$ providing for the taxation of real and personal property, and the latter was defined so as to include only the more tangible classes of personalty. ${ }^{2}$ This measure was really supplementary to the Baldwin Act ( 1849 ) in that its aim was "to provide a more equal and just assessment for municipal and local objects and purposes" in the various newly created municipalities. All taxes were to be levied on the whole taxable real and personal property of the locality, in proportion to the assessed value thereof, and not upon any one kind of property in particular. The assessors were to estimate all property at its actual value, "as they would appraise the same in payment of a just debt due from a solvent debtor." In townships and counties the rate was to be ascertained by dividing the amount required by the total assessment value, while, in cities and towns, the council was to impose the taxes by by-laws declaring the yearly rate in the pound to be levied on the annual value of all taxable property. The annual value of personal property was declared to be six per cent of the assessed actual value and that of realty was to be the actual rackrent, to be ascertained for each separate holding.

This limited taxation of personal property lasted only until $1853,{ }^{3}$ when the first general property tax of Upper Canada was instituted. The assessment act of that year

113 and 14 Victoria, c. 67.

${ }^{2}$ Horses and cattle, 3 years old and over; carriages for pleasure or hire; average stocks of merchants; shares in ships, etc.

- 16 Victoria, c. 182. 
provided that all land and personal property should be taxed, and included in the latter category all property except land and the improvements thereon. This act with various amendments has served as the basis of local assessment in the upper Province until recent years.

In both Nova Scotia and New Brunswick, where, as late as the seventies, the Courts of Sessions had power to raise money for local purposes, ${ }^{x}$ the definition of taxable property includes personalty. As early as 1763 we find an assessment act in Nova Scotia providing for the taxation of real and personal property, "in just and equal proportion." An act of 1856 defined personalty so as to include personal chattels, stock-in-trade, money and ships (to one-half value), thus removing from the jurisdiction of the assessors the definition of taxable property. In I 849 a general property tax was introduced in the city of Halifax, when taxable personalty was defined as furniture, moneys, merchandise, ships, debts, securities and stocks.

A New Brunswick act of 1786 authorized the assessors to levy the amounts required as they thought "just and reasonable." The act of $\mathrm{I} 822$ provided that onehalf the sum required be levied as a poll tax and the remainder on property. Nine years later the proportion to be collected as a poll tax was reduced to one-eighth, and taxable property was defined as all "visible" property and income. In I850, the assessors were directed to assess real and personal property at one-fifth their full value and income at its full value. This provision was repealed in 1875 .

Quebec stands out prominently as the only Province

1 Bourinot, Local Government in Canada, p. 221 ; Murray, Local Government in Maritime Provinces, pp. 50 et seq., in Toronto Univ. Studies, vol. 2. See Murray, note pp. $65-7$, for early legislation. 
which has not had recourse to a tax on personal property. The French-Canadian majority has always been opposed to direct taxation in any form and has regarded with disfavor any move toward an extension of the system so as to include all classes of property. In the eighties, when the growth of trade and commerce had increased the amount of personalty in the cities, an effort was made to reach this form of wealth which had hitherto escaped taxation. The experience of Ontario and of the American states, as well as the opposition of the FrenchCanadian agricultural class, prevented the introduction of the personal property tax. A substitute, suggested by the system in vogue in France, ${ }^{x}$ was found in the special business taxes for Montreal and Quebec. ${ }^{2}$

Ontario and the Maritime Provinces had fairly well developed systems of taxation of general property before the institution of any organized scheme of taxes on realty alone in Quebec. This early development was due to the experience of the inhabitants of these Provinces in the colonies to the south. The large majority of the United Empire Loyalists, who came to Canada in I784, settled in the upper Province (Ontario) and in Nova Scotia and New Brunswick. Families and groups of families migrated together and settled in the same district, bringing with them their political customs and ideals. Nova Scotia's relations with the New England colonies had always been close and we find the personal property tax introduced here as early as i763. The rapid development of the system in Ontario was due, as we have seen, to the financial straits of the Central Government.

${ }^{1}$ Vide Leroy-Beaulieu, Traité de la science des finances, 6me ed., pp. 449-480.

${ }^{2}$ Vide infra, p. 48. 


\section{CHAPTER IV}

\section{The Failure of the Personal Property Tax}

We have seen how the Province of Quebec has avoided a tax on personal property and has introduced in its stead the taxation of business. ${ }^{x}$ Ontario has had a more varied experience. No serious complaints arose for almost a generation after the inception of the general property tax in 1853 . But, with the rapid development of trade and commerce in the eighties, it was not long before the inequalities of the system became apparent. The Ontario Commission on Municipal Institutions of I 888 declared that "the valuation of personal property varies so much as almost to prove prima facie that this cannot be an equitable basis of taxation."

It was not, however, until a few years ago that final steps were taken to remove the evils in the tax system. A special commission, appointed in September, I900, to enquire into the operation of the assessment laws then in force and to suggest improvements, has published two reports ${ }^{2}$ dealing with the various questions connected with taxation. The Commissioners condemn the personal property tax in the following words: "One conclusion which can unhesitatingly be drawn is that the tax on personal property is a failure, and that it is a hopeless task to attempt to perfect it by further legislation. It should, therefore, be abolished." 3

1 Vide supra, pp. 37-8 and also infra, chap. 5.

2 Ig0I and 1902.

${ }^{3}$ Report of 1902, p. 24. 
An examination of the working of the Ontario system shows the utter failure to reach all classes of personal property and the consequent overburdening of wealth in other forms. The defects of the personal property tax, familiar to students of American local taxation, ${ }^{2}$ were all to be found in Ontario, with the exception of that arising from the apportionment of the state tax on the localities. The Consolidated Assessment Act of $1866^{2}$ defined personal property as "all goods, chattels, interest on mortgages, dividends from bank stock, dividends on shares or stocks of other incorporated companies, moneys, notes, accounts and debts at their actual value, income," and all property, except real estate and property expressly exempted. From time to time exemptions had been introduced with a view to the prevention of double taxation and for purposes of public policy. These, instead of removing the inequalities, had accentuated them. The principal exemptions were as follows: ${ }^{3}$

I. Dominion, Provincial and municipal debentures.

2. Stock in toll roads and income derived therefrom.

3. Personal property invested in mortgages on land, or due as purchase money for land. (The interest on mortgages was assessable).

4. Stocks in a company whose personal estate is liable to assessment in the Province.

5. Bank stocks. (Dividends assessed against shareholders).

6. Stocks in railway companies. (Dividends assessed against shareholders).

7. So much of the personal property of any person as is

${ }^{1}$ Cf. Seligman, Essays in Taxation, pp. 23-61; Ely, Taxation in American Cities and States, pp. I31 et seq.; Lawson Purdy, The Taxation of Personal Property (New York Tax Reform Assn., 1907).

2 29-30 Victoria, c. 53 .

${ }^{3}$ Rev. Stat. of Ontario 1897, c. 224, s. 7 . 
equal to the just debts owed by him on account of such property.

The result of the lack of any definite principle which can be seen from this survey, was to make the tax payable on a sum of money vary according to the character of the investment made. The table below, printed in the Commission's report of $1902,{ }^{x}$ gives the amounts payable for a few of the possible modes of employing money.

Assuming the tax rate to be 2 per cent,

(a) $\$ 100,000$ in the bank (interest at 3 per cent) should pay .......\$2,coo

(b) $\$ 100,000$ invested in Dominion, Provincial or municipal bonds...... Nil.

(c) $\$ 100,000$ invested in mortgages on land (interest 5 per cent) $\ldots \ldots$ r... roo

(d) $\$ 100,000$ invested in business by cash purchase of goods ......... 2,000

(e) $\$$ roo,00o invested in purchase of land..................., 2,000

(f) $\$ 100,000$ invested in bank stock (net returns 5 per cent) $\ldots \ldots \ldots$ 100

(g) $\$ 100,000$ invested in stock of toll roads.................... Nil.

(h) $\$ 100,000$ lent on notes (interest at 7 per cent) $\ldots \ldots \ldots \ldots \ldots \ldots, 2,000$

or.... I 40

as the assessor chooses, but more probably pays ........ Nil.

(i) $\$ 100,000$ invested in foreign securities $\ldots \ldots \ldots \ldots \ldots \ldots \ldots \ldots \ldots \ldots \ldots \ldots \ldots \ldots$ Nil.

This was the result of the tinkering done by the Legislature. In actual practice, the personal property tax had become a tax on the stocks-in-trade of merchants, except in the few cases where income was reached. The inequalities and the uncertainty of the system placed the merchants at a decided disadvantage as compared with those of the large cities of the neighboring Provinces, and there were instances of large firms having migrated to Montreal and Winnipeg, neither of which taxed personalty. On the whole, it may be said that any attempt to enforce the personal property tax proved unfavorable to the growth of distributing centres.

1 Page I4. 
The exemption of debts due on personal property placed a premium on dishonesty by encouraging the creation of fictitious debts. Thus an additional burden was placed on real property, from the value of which no exemption was made for debt, except where it could be shown that such was due as part of the original purchase money. The evidence taken by the Commission ${ }^{x}$ shows numerous instances where, on account of debts due, either real or fictitious, no tax was paid by firms which were in competition with others conducted on a cash basis and, therefore, paying large taxes.

Not only did the much greater part of personalty escape taxation, but the evasion increased from year to year. The following statistics of the five largest cities of Ontario show the proportion of the taxes borne by real and personal property: ${ }^{2}$

\begin{tabular}{|c|c|c|c|}
\hline Name of City & Year. & Real Property. & Personal Property. \\
\hline Hamilton & $\begin{array}{l}1886 \ldots \ldots \ldots \ldots \ldots \ldots \\
1896 \ldots \ldots \ldots \ldots \ldots \ldots \\
1899 \ldots \ldots \ldots \ldots \ldots\end{array}$ & $\begin{array}{l}.784 \\
.866 \\
.856\end{array}$ & $\begin{array}{l}.216 \\
.134 \\
.144\end{array}$ \\
\hline Kingston . & $\begin{array}{l}1886 \ldots \ldots \ldots \ldots \ldots \ldots \\
1896 \ldots \ldots \ldots \ldots \ldots \ldots \\
1899 \ldots \ldots \ldots \ldots \ldots\end{array}$ & $\begin{array}{l}.767 \\
.853 \\
.876\end{array}$ & $\begin{array}{l}.233 \\
.147 \\
.124\end{array}$ \\
\hline London & $\begin{array}{l}1886 \ldots \ldots \ldots \ldots \ldots \ldots \\
1896 \ldots \ldots \ldots \ldots \ldots \ldots \\
1899 \ldots \ldots \ldots \ldots \ldots\end{array}$ & $\begin{array}{l}.787 \\
.858 \\
.855\end{array}$ & $\begin{array}{l}.213 \\
.142 \\
.145\end{array}$ \\
\hline Ottawa.. & $\mid \begin{array}{l}1886 \ldots \ldots \ldots \ldots \ldots \ldots \\
1896 \ldots \ldots \ldots \ldots \ldots \ldots \\
1899 \ldots \ldots \ldots \ldots\end{array}$ & $\begin{array}{l}.886 \\
.922 \\
.925\end{array}$ & $\begin{array}{l}.114 \\
.078 \\
.075\end{array}$ \\
\hline Toronto & $\begin{array}{l}1886 \ldots \ldots \ldots \ldots \ldots \ldots \ldots \\
1896 \ldots \ldots \ldots \ldots \ldots \ldots \\
1899 \ldots \ldots \ldots \ldots \ldots\end{array}$ & $\begin{array}{l}.837 \\
.907 \\
.890\end{array}$ & $\begin{array}{l}.163 \\
.093 \\
.110\end{array}$ \\
\hline
\end{tabular}

${ }^{1}$ Report of Igor, passim.

${ }^{2}$ From Report of 1902, pp. 39-40. 
The above figures show that in 1899 , the year before the work of the Commission began, personalty in these cities paid only from seven and five-tenths per cent to fourteen and five-tenths per cent of the total amount of the taxes, in spite of the fact that, in every modern city, the actual value of personal property greatly exceeds that of realty. In every instance the proportion of the burden borne by personalty shows a decrease. The Commissioners, in their recommendation for the abolition of the tax on all personal property except income, were influenced both by the inequality as between realty and personalty and by the apparent driving-out of capital by pressure on commercial and industrial concerns. They were of the opinion that the substitute offered by them would yield at least as much as the tax on personal property and at the same time would distribute the amount of taxation more equally. ${ }^{\mathrm{I}}$ Their suggestions for the improvement of the system of assessment may be summarized as follows: ${ }^{2}$

I. Where a person's income is derived from trade, manufacture, or financial or commercial business (private bankers and brokers excepted) in cities, towns, and villages, tax the person by reference to the rental value of the premises occupied for the purpose of his business or occupation, instead of directly upon income.

II. In the case of persons following other callings (including private bankers and brokers), exempt income up to $\$ 1,000$; where income is more than $\$ 1,000$, but not more than $\$ 4,000$, tax the person by reference to the rental value of the premises occupied for the purpose of his business or occupation, instead of directly upon income.

III. Where the income of such person exceeds $\$ 4,000$, he

1 Report of 1902, p. 24.

${ }^{2}$ Report of 1902, pp. 35 and 8-9. 
shall be assessed by reference to the rental value up to $\$ 4,000$ and directly upon the amount in excess of $\$ 4,000$.

IV. Tax income directly of persons having no calling.

V. Impose, in cities, towns and villages, as a supplementary $\operatorname{tax}$, a tax on all owners and occupiers of houses ...... by assessing them for the rental value of the houses, subject to a deduction by way of exemption.

While this system is based ostensibly on income, no effort is made to arrive at uniformity, income being taxed directly in some cases at the same rate as rental in others. The Assessment Act adopted in $1904^{x}$ abolished the personal property tax, and, in its place, instituted a system of business assessments based on the value of the real estate occupied. ${ }^{2}$ It contains no provision for a habitation tax such as was recommended by the Commission.

This act was soon followed by a measure ${ }^{3}$ of the Manitoba Legislature providing for the abolition of the personal property tax in all the towns and villages of that Province, and for the substitution of a tax of twelve and one-half per cent on the rental of the premises occupied for business purposes. As early as 1893 the city of Winnipeg had abandoned the personal property tax and had substituted a tax on businesses, thereby helping to build up the city as a distributing centre for the West. In the city of Portage la Prairie the tax on personalty was abolished in 1907.4 Here, between the years 1890 and I900, the assessed value of realty increased by forty-six and four-tenths per cent, while that of personal property increased only one and seven one-hundredths per cent. Manitoba as a whole has followed Ontario in its efforts to establish an equitable and uniform system of taxation.

14 Edward VII, c. 23.

85 and 6 Edward VII, c. 53.
2 Vide infra, chapter $\mathrm{v}$.

46 and 7 Edward VII, c. 53. 
In all the Provinces, which have the personal property tax, a decided movement can be seen in favor of its abolition. Edmonton and Strathcona, in the Province of Alberta, have adopted the business assessment, and the tax on personalty is found only in the other cities and towns and in some of the villages of the Province. In Saskatchewan, the report of the Municipal Commission of 1907 recommends the application of the Edmonton system of business assessments, which at that time was in use in Regina and Saskatoon, to all the cities, towns and villages of the Province. It was provided by the Cities and Towns Acts of $1908,{ }^{x}$ that these municipalities should levy their taxes upon lands, businesses, incomes and special franchises.

British Columbia has come to the conclusion that under the personal property tax a fair share of the burden of taxation is not borne by those businesses in which it is not necessary to carry large stocks but which have large annual returns. The Assessment Commission of I905 considers it desirable "that, inasmuch as it seems impossible to formulate a plan for taxing personal property in a way that will bear equitably on all classes, the system of taxation should be directed with the ultimate object of substituting an income tax for any impost on personal property." 2 It is highly probable, therefore, that the next few years will see the abandonment of the personal property tax by the Province of British Columbia.

In Nova Scotia and New Brunswick also there are evidences of general dissatisfaction with the system of taxation. The present method of municipal assessment is acting as a check on the commercial development of the

18 Edward VII, cc. 16 and 17.

2 Report of February 16, 1905. 
cities of both Provinces, and merchants and manufacturers are growing restive under a system which gives an advantage to their competitors in Quebec and Ontario. The city of St. John, Canada's winter port, by the appointment of a commission to investigate the working of the tax, has taken a step in the direction of removing this handicap upon its industrial and commercial expansion. The commissioners found that, although personal property was paying about forty-six per cent of the total taxes, the larger part of the holdings of the wealthier residents was escaping taxation. Considering the absolute abandonment of the personal property tax inadvisable on account of the large proportion of the assessment borne by that class of property, they recommended that merchandise and movable machinery be assessed at fifty per cent of their values and that all other forms of personalty be taxed upon the value of the income derived therefrom capitalized at five per cent. In addition, they advised the imposition of a business tax similar to that instituted in Ontario and a tax on residences, the whole to be supplemented by various other special taxes." While the scheme of taxation suggested is unnecessarily complicated and devoid of any theoretical justification, the report of the commission, in setting forth the weaknesses of the old system, has made a beginning in the direction of reform.

In contrast with the meagre results in the way of reform produced by the complaints raised against the personal property tax in the various states of the American Union and by the many declarations against the system by state commissioners and others, Ontario and the

${ }^{1}$ Vide Murray, Loc. Govt. in Mar. Provs., p. 65, in Tor. Univ. Studies.

2 Vide Report of the Assessment Law Commissioners, November, 1906. 
western Provinces have not been slow in their recognition of the disadvantages of this system. The chief factor in bringing to a head the agitation for abolition was the disadvantageous position of Ontario's merchants as compared with their competitors in Quebec and Manitoba. The business element in Ontario has always been politically strong, and its influence is seen, not only in the abolition of the old system, but in the provisions for a substitute. Another important point to be noted here is that the legislators of the Canadian Provinces are not hampered by constitutional restrictions, the removal of which must be the first step in reform in most of the American states. 


\section{CHAPTER V}

\section{The Business Assessment :}

\section{A SUBSTITUTE FOR THE PERSONAL PROPERTY TAX}

ONE of the great obstacles to the improvement of local taxation is the difficulty encountered in providing a suitable substitute for the tax on personalty. To show that such a substitute, desirable from the viewpoint both of the administrator and of the taxpayer, may be found in a system of business taxes is the purpose of this chapter.

Provisions for special taxes on business are now in force in five out of the nine Canadian Provinces. As early as $1866,{ }^{x}$ we find the city of Quebec authorized to levy specific rates on business. But it was not until the commercial development of the eighties that any systematic attempt was made to levy taxes of this nature. In $I 887,,^{2}$ provision was made for a proportional rate on trade and commerce in the city of Quebec, and the municipal council fixed this rate at 12.5 per cent on the rental value of the premises occupied, where it still remains. Two years earlier, ${ }^{3}$ Montreal had been authorized to levy a similar tax. This city ${ }^{4}$ now imposes a rate of seven and one-half per cent on the rental of all merchants, manufacturers and financial or commercial institutions, with a special tax on brewers and distillers,

${ }^{1}$ 29-30 Victoria, c. 57.

48 Victoria, c. 67.

48
250 Victoria, c. 57.

4 Civic by-law no. 236. 
banks, insurance companies, and brokers and agents. This method, while it has given rise to no serious complaints, lacks uniformity in failing to discriminate between classes of business where there is great variation in the ratio of rental to income.

The Provincial Government of Quebec also has a system of "licenses" on trades and professions. " Persons having their principal place of business in Montreal or Quebec are required to take out licenses, the fee connected with which is five per cent of the rental of the premises occupied; in other municipalities, unincorporated manufacturers and wholesale merchants must pay $\$ 50$ or $\$ 30$, according to population, and retail dealers $\$ 20$ or \$1o. Professional men in Montreal and Quebec pay five per cent of their rent, in other cities and towns the sum of $\$ 6.00$, and in other municipalities $\$ 3.00$.

The city of Winnipeg in $1893^{2}$ abandoned the personal property tax and substituted a system of business assessments based on a capitalization of rental value at rates varying from three and one-third to five for certain classes of business and professions, and on the amount of floor space occupied where the rental value exceeded seventy-five cents per square foot. This system, instituted only as a temporary measure, was changed in $1907^{3}$ by the substitution of a flat rate of eight and onethird per cent on all business rentals. But, owing to difficulties which arose in regard to the assessment of hotels, the old system was restored temporarily a year later. ${ }^{4}$ In the session of $1909^{5}$ the Legislature enacted that the business taxes should be at the rate of six and two-thirds

${ }^{1} 57$ Victoria, c. II (1894).

- 6 and 7 Edward VII, c. 48.

6 Edward VII, c. 78, sections 20 and 2 I.
${ }^{2} 56$ Victoria, c. 24.

4 and 8 Edward VII, c. 66. 
per cent on the annual rental of premises occupied for business purposes, certain classes of business which are subject to municipal license being excepted. This rate is levied in the case of hotels only on the annual rental value of the ground floor of the hotel building.

In $1900,{ }^{x}$ the city council of Brandon was authorized to levy a business tax of 12.5 per cent on the rental of the premises occupied, as well as special taxes on banks, telegraph and telephone companies and electric plants. The Manitoba Assessment Act of $1906,{ }^{2}$ which comes into force in any particular town or village upon proclamation of the Lieutenant-Governor to that effect, provides for the abolition of the tax on all personal property in the incorporated towns and villages of the Province and for the substitution of a business tax not to exceed 12.5 per cent of the rental of the premises occupied.

In 1906,3 the Legislature of Saskatchewan amended the assessment laws affecting the cities of Regina and Saskatoon by abolishing the personal property tax and basing the system on the assessment of lands, businesses, income and special franchises. ${ }^{4}$ Businesses are defined so as to include any trade, profession, calling, occupation or employment; and the method followed is that of ascertaining the business assessment by means of a rate per square foot of floor space occupied, a plan which had already been put into operation in Edmonton, Alberta. ${ }^{5}$ The Saskatchewan Cities and Towns Acts of $1908^{6}$ ex-

163-4 Victoria, c. 55 .

${ }^{2} 5$ and 6 Edward VII, c. 53 .

${ }^{3} 6$ Edward VII, cc. 46 and 47.

"The Assessment on "Special Franchises" is one on the actual cost of plant and apparatus in addition to that on real estate.

${ }^{5}$ Vide Edmonton Charter, N. W. T. Ordinances, 1904, c. 19.

${ }^{6} \mathrm{Ig08}, \mathrm{cc}$. 16 and $\mathrm{I7}$. 
tended the above system to all cities and towns in the Province, amending the business assessment so as to include brick and lumber yards and other trades in which no buildings are used.

Under the Edmonton method of assessing businesses, the assessors are required to "fix a rate per square foot of the floor space... of each building or part thereof used for business purposes," and, as far as they deem practicable, "to classify the various businesses and... to fix a different rate for each." " This rate must not exceed $\$ 5.00$ per square foot, except in the case of banks and other financial institutions, when $\$ 10.00$ is to be the maximum. The 1908 rate varied from $\$ 0.25$ per square foot for factories and florists to $\$ 7.50$ for banks. The most common rate is $\$ 4.00$ (retail stores and offices), and that for retail and wholesale stores requiring large floor space varies from $\$ 1.50$ to $\$ 3.00$. After making an estimate of the amount required to be raised by taxation, a uniform tax rate is struck for all classes of taxable property.

There is much to be said both in favor of and against this method of business assessment. It is convenient for administrator and for taxpayer, since the amount of taxes payable is easily ascertained, and the differential rate, though arbitrary, tends to greater equality between the various classes of business. But the floor-spacemeasurement system is crude, since space occupied bears no fixed ratio to the amount of capital invested nor to the returns from the business. The chief argument against the system of assessment taken as a whole is the lack of uniformity, no effort being made to arrive at the just proportion which each class of taxable property

${ }^{1}$ Edmonton Charter, title $\mathrm{xxxii}$, section 3. 
should bear. Even this plan of business assessment, however, is a decided move toward a more equitable basis of taxation than the old personal property tax.

We may now turn to that Province in which the assessment of businesses has reached its highest development in Canada. The Ontario Assessment Act of $1904{ }^{x}$ by which, as we have seen, the Legislature relinquished the attempt to tax personalty, introduced a system of business assessments based on the value of the real estate occupied. This act provides that every person occupying real estate for business or professional purposes shall be assessed for a sum equal to the following proportions of the assessed value of the real estate so occupied:

(a) Distillers................................. 150 per cent

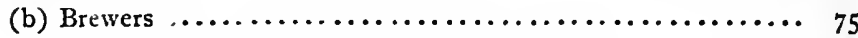

(On portion of land used as maltirg hcuse) .......... to "

(c) Wholesale merchants, irsurance, loan and trust, express and land companies, banks and other financial institutions.....

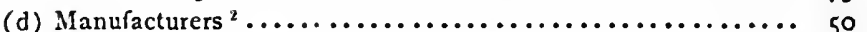

(e) Departmental stores (where the assessed value of the premises exceeds $\$ 20, c c 0)$, coal or wood dealers, lithcgraphers and printers................................ 50

(f) Professional men, financial and commercial agents ${ }^{3} \ldots \ldots \ldots$ 50

(g) Newspaper publishers, in cities.................. 35 " “ in other municipalities $\ldots \ldots \ldots \ldots \ldots .25$

(b) Retail merchants :

(I) In cities with population over $50,000 \ldots \ldots \ldots \ldots \ldots .25$

(2) In otber cities and towns with a population of 10,000

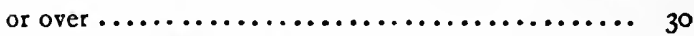

(3) In all other municipalities $\ldots \ldots \ldots \ldots \ldots \ldots \ldots \ldots, 35$

${ }_{4}$ Edward VII, c. 23.

2 Flour mills producing on an average less than 50 bbls. per day, 35 per cent (ro Edward VII, c. 88, s. 6).

3here such persons use land partly for business and partly for residential purposes, 25 per cent of the assessed value is taken for business assessment. 
(i) Photographers, theatres, concert halls, boarding and livery stables, restaurants, etc. ........................ 25 per cent

(j) Telegraph, telephone, street railway, gas and electric companies................................... $25^{1}$ “

(k)

No person may be assessed in respect of the same premises for more than one class of business. Should more than one kind of business be conducted on the same premises, the assessment is made under that clause which includes the "chief or preponderating business" so carried on. ${ }^{3}$ Where the amount of the business assessment of any one person under these provisions is less than $\$ 250$, it is fixed at \$10o. As in Alberta and Saskatchewan, the rate of taxation is uniform on all classes of ratable property and income.

A glance at the method by which the Legislature arrives at the above percentages will serve to show that the reform is not so revolutionary in character as one might at first conclude.

The business assessment ... has been so graded and the persons subject to it so classified that the assessments under it, when made, will, it is hoped, relatively, if not actually, represent amounts which might be assessed against each person if they had been arrived at by an actual inspection and valuation of the personal property of the person, and "business assessment" may, therefore, be regarded as a satisfactory substitute for the assessment of personal property. ${ }^{4}$

In other words, the classification is based on the per-

1 Not to include assessment on wires, rails, plants, etc.

2 Amendment of 10 Edward VII, c. 88, s. 4 (2).

Section Io(2).

4 Report of the Special Committee in the Journals of the Legislative Assembly, vol. xxxviii, 1904, pp. I37-9. 
sonal property assessment as it stood at the time of the framing of the act, the chief aims of the Legislature being the realization of some degree of uniformity within the business assessment itself and the removal of all incentives to dishonesty without causing a falling-off in the local revenues.

This method of assessment is superior to the taxation of personalty, since it prevents any decrease in the proportion of total taxes payable by business. But it is evident that the scheme of business assessments, being based on the old system, is inequitable to the extent that personal property was evading taxation at the time of calculating the percentages. The chief arguments, therefore, which may be brought to bear against the system are that it is still a property tax, and that, owing to the more or less arbitrary method of assessment, it fails to secure equality of taxation. In the main, however, there have been no complaints, and the municipalities have increased their revenue by bringing all merchants, manufacturers and professional men under assessment.

The advantages of the system may be summed up as follows :

(a) It is convenient to both assessor and taxpayer since the amount of tax payable is easily ascertained. It is no longer necessary for the assessor to "make a guess," as an Ontario assessment commissioner expressed it, at the amount for which an individual is to be assessed, nor is the taxpayer required to submit to any investigation of his private affairs.

(b) The differentiation between the classes of industry is an improvement on the Quebec and Manitoba system of levying a flat rate on rentals. But divisions should also be made within some of the present classes to allow for the differences between the various kinds of trades.

(c) The system tends to bring about greater equality with- 
in the field of commerce and industry since all are liable to taxation regardless of the amount of debts due.

(d) By changing the basis of assessment from the value of the stock carried to that of the real estate occupied, a check upon commercial development has been removed.

Viewing the Ontario system of local taxation as a whole, we see at once the absence of any scientific basis. Real estate is taxed at its full value and businesses and professions upon fictitious values. The revenue from these sources is supplemented by a tax on incomes, and, within the business assessment itself, income is levied on, in certain cases, when it exceeds the amount ascertained by taking the percentage of the real estate assessment. ${ }^{x}$ We, therefore, have two bases of taxation, property and income. No system of taxation can be equitable under such conditions. The whole scheme should be based on property or on income, on capital or on earning power.

Before attempting to construct an equitable system, it is requisite to inquire into some of the fundamental principles of taxation. That Adam Smith's first maxim of taxation, equality, is of prime importance is generally agreed, but there is considerable difference of opinion as to the definition of this equality. The principle according to which taxation should be levied if equality is to be secured will reveal itself in an examination of the character of a tax.

Among the theories that have been formulated are the closely related "benefit" and "purchase" theories of taxation, bcth of which have long since been abandoned by economists, but are still referred to by tax officials

${ }^{1}$ Vide Assessment Act, section II. 
and tax payers. ${ }^{2}$ Professor Seligman ${ }^{2}$ defines a tax as "a compulsory contribution from the person to the government to defray the expenses incurred in the common interest of all, without reference to special benefits conferred." A tax is thus "a part of a common burden" and its benefit to the individual, which is merely incidental, "is not susceptible of direct measurement." ${ }_{3}$ Professor Adams, in speaking of the "purchase" theory, says,

It implies . . that the state is something separate from the body of the citizens, and does not fit itself easily to the conception that the state is the body of the people organized for governmental purposes. It implies, in the second place, that the citizen is at liberty to refuse the services offered by the government, and by refusing is able to escape the necessity of making payments. It implies, in the third place, that the relative duty of citizens to make payment for the support of the government is in proportion to the expense which they occasion."

A tax, therefore, is not a price, but a "contribution from the citizens for the support of the state." 5

Following the benefit theory of taxation to its logical conclusion, the state, the chief result of the organization of which is that "might" is no longer "right," should demand from the poor and the weak a larger amount than from those more advantageously situated. This is manifestly unjust. We must conclude, therefore, that a tax is a contribution, demanded by the state from the in-

1 Vide Ontario Assessment Commission Report, rgor, passim.

${ }^{2}$ Essays in Taxation, p. 304.

s Ibid., p. 275.

- Science of Finance, p. 299; cf. also Mill, Prin. of Pol. Econ., bk. 5, ch. ii, s. 2, and Bastable, Public Finance, pp. 252-3.

- Adams, op. cit., p. $30 \mathrm{r}$. 
dividuals within its jurisdiction, according to the ability of each, for the maintenance of a fund to be expended in the general interest. The modern state does not consist of the government and the governed between whom bargains are driven, but is an organization of individuals for the common good with the government as its agent. The contribution of each individual to the expenses of the government should be on the same principle as that followed in the family organization and in various religious and other similar voluntary societies, namely, in accordance with the ability of each member.

The question which at once arises is, "How shall we measure ability to pay?" Is property or expenditure or income a just measure of ability? The United States have long taken property as an index, while England, France, Germany and other European countries have laid more stress on ircome, France taking expenditure in the form of rent as representative of income.

The aim of all governments, in devising schemes of taxation, should be to avoid trenching on capital. The contributions for the support of the state should be made from income if capital needed for further production is to be kept intact. Since the ratio of income to the property from which it is derived is not the same in all cases, it is evident that, under a system of taxation based on wealth, there will be great danger of encroachment on capital in those cases where the rate of returns is low. An individual's annual expenditure must depend upon his annual income; his ability to supply himself with the luxuries and the necessaries of life must be measured by his revente. It is therefore apparent that, if taxes are to be paid out of income, the amount of such income must be taken as the measure of ability to pay. Only by so doing will it be possible to attain any degree of equality. 
Owing, however, to the inquisitorial character of an income tax, it is difficult of administration. There are times in the careers of most merchants and manufacturers when the success or failure of their businesses depends upon the maintenance of secrecy. An inyuisitorial system would make it impossible to conceal a lean year, and one dependent upon returns from the taxpayer inevitably leads to such perjury and evasion as to render the tax farcical. A direct income tax is always accompanied by fraud. ${ }^{x}$ We must, therefore, devise some means by which we may be able to tax income indirectly. In an ideal static state all property would yield the same rate of returns and a property tax would fall equally upon all incomes. We have seen, however, that the conditions which prevail under the complications of modern industry render inequitable a system of taxation based on the ownership of property as an indication of the amount of income. Nor is expenditure for consumption, in any of its forms, more reasonable as a measure of income. Consumption bears no fixed ratio to revenue. An individual living alone in a few rooms may have a much greater income than the man whose large family compels him to expend his total earnings.

We must, therefore, base our indirect income tax, not on property, nor on expenditure, but on some better index of earning power. This may be found in a system of business assessments constructed so as to make earnings from this source bear their share of the burden of taxation. Our aim must be the devising of a scheme that will enable the tax-collecting authorities to take the same proportion of the earnings of individuals regardless of whether these earnings are derived from real or from personal property.

1 For objections against income tax, see Report of Special Tax Commission of New York State, Ig07, pp. 46-51. 
The first step is to ascertain as nearly as possible the amount of income derived from every business and profession the pursuit of which is dependent upon the occupation of real estate. Next we fix for each individual business or profession a tentative assessment by capitalizing this income at a rate such that its ratio to the tentative business assessment will be the same as the ratio of the gross rental of the premises occupied to the assessment of such premises. In other words, the tentative business assessment will be such that if the same tax rate were levied on it and on the real estate assessment, the same proportion of the income from each source would be taken. The third step is to find the ratio, in each case, of this tentative business assessment to the rental of the premises occupied, and to average the ratios thus obtained for each class of business or profession, making the class division as narrow as possible. In this manner, we may derive for each class of business an index number, the product of which by the rental of any individual business in a class gives us the amount of assessment of that business. The index numbers for all the classes, ascertained in this manner, will give us a schedule for all businesses and professions.

It may be argued that difficulty will be encountered in the first step, the ascertainment of income. But, when we remember that England, Prussia, Switzerland and several other countries have an income tax system under which the amount of income received is ascertained annually, this loses much of its weight. What is practical in these countries annually is surely so in Canada or the United States for the purpose of working out a schedule which would render further investigation of a similar character unnecessary, at least, for a number of years. Legislation could be introduced authorizing 
the investigators to demand statements from all individuals who would be liable to the tax. The statements thus obtained need not be binding on the investigators, who could be given authority to alter the amounts therein stated according to evidence obtainable. The dishonest tax payer would obtain no advantage over others in the same class, since the ratio found for his particular case would be averaged with those for all other members of the same class. The collection of the material necessary for the working-out of the schedule would require no little effort and expense, but, once completed, the cost of assessing businesses and professions would be negligible.

It will be noticed that gross rental is used in estimating the tentative business assessment, thus making the result lower than if net rent ${ }^{x}$ were made the basis of the calculation. Net rent is difficult to ascertain, and it is desirable that income derived from real estate should bear a proportionately higher levy than that from personal effort.

Incomes derived from sources which would not be reached by this business assessment could be assessed separately, after having been capitalized at such rates as might be deemed equitable in comparison with the assessment on real estate and businesses. Upon these three classes of taxable property, the same rate of taxation should be levied, as is now done in Ontario and some of the other Provinces. The variation of this rate in any municipality according to the annual expenditure will attract the attention of the taxpayers to any extravagance on the part of the local authorities.

The system as a whole is revolutionary only in the sense that it makes income rather than property the basis

${ }^{1}$ After deducting for repairs, etc. 
of assessment. The assessment of real estate remains unaltered, that of the other two classes being changed so as to obtain an approximate uniformity as between the three classes and between the individuals taxable under the business assessment. Should the taxation of businesses to the full amount ascertained by the above method be considered inadvisable, a proportionate reduction could be made throughout the schedule of business assessment rates. This would reduce the burden on businesses as a whole without affecting the relations between the classes of business.

The size of the classes would depend upon the result of the calculation, since it would be possible to combine different kinds of business having the same index number. It might also be expedient to subdivide the classes according to the population of the municipality in which the businesses are situated. This also would be determined, in drawing up the schedule, in accordance with the results obtained.

It is possible that this system may be criticised on the grounds that returns from business bear no fixed ratio to the rental of the premises occupied and that a tax on rental is, therefore, inequitable. This is undoubtedly true when stated thus generally, but the argument is weakened when we recall that differentiation is to be made between the various classes of business. Within each class in any community there does tend to be a fixed ratio between income from business and the rental of the premises occupied, and, since the rates finally obtained for individuals would be averaged for each class, no injustice would be done, especially since the incomes on which the whole calculation would be based are likely to be lower than the real returns from the businesses. Assuming that none of the taxes is shifted, we must 
agree that this system is a decided improvement on the present Ontario scheme of taxation, which, as we have seen, is far more equitable than one which includes a tax on personalty. Every individual who earns an income from any source will be taxed directly or indirectly on that income. Should the real estate tax be shifted to the occupier, the effect would be a decrease in the burden on the occupiers of real estate for residential purposes, and hence a reduction in the tax on consumption, since the burden on all real estate would be lightened by the increase in the business assessment.

The proposed system is not perfect. We must remember that "La recherche de la complète justice en cette matière ressemble au probleme de la quadrature du cercle." Comparative, not absolute, merit is all that is claimed for it. Probably its greatest advantage lies in the facility with which it can be administered. Any merchant or professional man could at any time ascertain the amount of his assessment merely by finding the product of his rental by the rate for his class as set forth in the schedule. The assessors would have little difficulty in discovering the amount of rental paid in each case, and, by basing the system on rentals rather than on real estate values, as is the practice in Ontario at present, we should remove the community of interest on the part of land owner and occupier to reduce the real estate assessment. It would be to the interest of each class of taxpayers to have the assessment of the other as high as possible.

The system which has been outlined above includes all the advantages of the present Ontario system and at the same time is free from the objectionable features of that system.

${ }^{1}$ Leroy-Beaulieu, Traité de la science des finances, 6me ed., i, 459. 


\section{CHAPTER VI}

\section{INCOME TAXes}

IN none of the seven Provinces which attempt to reach income directly does this tax form the most important part of the system. It is everywhere a smail portion of the general scheme of taxation, a minor division of the taxes on property. Two Provinces, Quebec and Manitoba, make no effort to reach income directly; Ontario, Saskatchewan and Alberta levy a tax on income as a supplement to the taxation of lands and businesses; Nova Scotia and New Brunswick still attempt to reach income under the general provisions for the taxation of property; and Prince Edward Island and British Columbia have a Provincial tax on incomes.

Before the year 1905, the municipalities of Ontario assessed as personal property the incomes derived from all sources except real estate and personalty. The result was far from satisfactory. The assessors were seldom able to discover the true amount of such income, except in the case of salaried persons, who were thus made to bear almost the whole weight of the tax. ${ }^{\text {" Statistics }}$ published in the Commission Report of $1902{ }^{2}$ show that, in practically all cases, there was either a constant absolute decrease in the amount of income assessment or the ratio of income to total assessment was steadily diminishing.

1 Commission Report, 1902, p. 13.

63]

2 Pp. 35-6. 
The Assessment Act of 1904 continued the provisions for the taxing of incomes, but made the liberal professions and all callings, the pursuit of which is dependent upon the occupation of real estate, taxable under the business assessment. ${ }^{x}$ This furnished a fixed basis on which to assess that large class of incomes, the ascertaining of which had hitherto depended on self-assessment. Under the present system, all engaged in the above callings must pay their contribution to the municipality. Furthermore, the assessor is not limited to an assessment of fifty per cent of the value of the real estate occupied by professional men, but he is empowered to assess for a greater amount whenever the actual income exceeds the amount of the business assessment.

Income is defined ${ }^{2}$ in the act of 1904 as,

The annual profit or gain or gratuity (whether ascertained and capable of computation as being wages, salary, or other fixed amount, or unascertained as being fees or emoluments, or as being profits from a trade or commercial or financial or other business or calling) directly or indirectly received by a person from any office or employment, or from any profession or calling, or from any trade, manufacture or business, as the case may be ; and shall include the interest, dividends or profits directly or indirectly received from money at interest upon any security or without security, or from stocks, or from any other investment, and also profit or gain from any other source whatever.

All such income is to be taxed, subject to the following exemptions: ${ }^{3}$

(a) Incomes derived from farms and from real estate generally, except interest on mortgages.

1 Vide supra, p. $5^{2 .} \quad$ 2 Section 2 (8). $\quad$ s Section 5. 
(b) Dividends from the stock of a corporation, the income of which is liable to assessment in the Province.

(c) Dividends from shares in toll road companies.

(d) Incomes from personal earnings, pensions, etc. $:^{1}$

(I) to the amount of $\$ 1200$, where the recipient resides in a city or town, and $\$ 900$ in any other municipality, where such recipient is a householder in the municipality where he is assessed;

(2) to the amount of $\$ 600$ in a city or town and $\$ 400$ in other municipalities when the recipient is not a householder;

(3) to the amount of $\$ 300$ derived from any investment, moneys or deposits, loans, etc., where the recipient is a householder or head of a family and is not in receipt of income from all sources exceeding the sum of $\$ 300 .{ }^{2}$

(e) Persons liable to business assessment, except in cases where such persons derive an income from sources other than the business for which they are assessed, and, in the case of professional men, when the income derived from such calling exceeds the amount of the business assessment. In the latter instance, income only is assessed. ${ }^{3}$

The act also provides the machinery by which the assessors can ascertain the amount of income. All employers are required to give information as to the wages or salaries paid to employees, and corporations must furnish to the officials of any municipality returns showing the amount of dividends and bonuses paid to any share-

16 Edward VII, c. 36 , s. I; 8 Edward VII, c. 50, s. 4; Io Edward VII, c. 88 , s. 2.

2 None are allowed to vote by virtue of their income assessment when such assessment is less than $\$ 400$. 3 Edward VII, c. I9, s. 86.

3 Assessment Act, s. II. 
holder who may be taxable in that municipality.' Any person who fails to furnish the information called for by the assessor incurs a penalty not to exceed $\$ 100$, and an additional amount of $\$ 10$ for each day during which the default continues. ${ }^{2}$ The extent to which recourse to selfassessment is necessary is limited by these provisions to the amount of income received from loans and similar investments and from revenues received from sources outside the Province.

That this section of the Ontario tax system has met with some degree of success may be seen from the following statistics ${ }^{3}$ showing the ratio of income assessment to total assessment and the amount of taxable income per capita in the five leading cities of the Province.

RATIO OF INCOME TO TOTAL ASSESSMENT

\begin{tabular}{|c|c|c|c|c|c|c|}
\hline & 1906. & 1907. & 1908. & 1909. & 1910. & 1911. \\
\hline Hamilton ...... & $\begin{array}{c}\text { Per cent } \\
4.7\end{array}$ & $\begin{array}{c}\text { Per cent } \\
3.6\end{array}$ & $\begin{array}{c}\text { Per cent } \\
3.4\end{array}$ & $\begin{array}{c}\text { Per cent } \\
3.4\end{array}$ & $\begin{array}{c}\text { Per cent } \\
3.4\end{array}$ & $\begin{array}{c}\text { Per cent } \\
3.1\end{array}$ \\
\hline Kingston....... & 3.1 & 3.7 & 3.6 & 4.0 & 4.1 & 3.9 \\
\hline London ......... & 4.2 & 4.4 & 4.1 & 4.2 & 4.2 & 3.9 \\
\hline Ottawa......... & 4.5 & $4 \cdot 7$ & 5.0 & $6.6^{4}$ & $6.7^{4}$ & 3.7 \\
\hline Toronto ....... & 5.2 & $4 \cdot 3$ & $4 \cdot 7$ & 4.9 & $4 \cdot 3$ & 4.0 \\
\hline
\end{tabular}

1 Sections 17 and 19.

${ }^{2}$ Section 2 I.

- Compiled from figures furnished by the assessment commissioners of these cities. The figures used for population are those of the municipal censuses.

4 Omitting civil-service incomes which were not taxed previous to 1909 and which were exempted in 1911 , the figures for 1909 and 1910 , respectively, are $4.4 \%$ and $4.8 \%$. 
TAXABLE INCOME PER CAPITA

\begin{tabular}{|c|c|c|c|c|c|c|}
\hline & I 906. & 1907. & I908. & 1909. & I910. & IgII. \\
\hline Hamilton ...... & $\$ 25.80$ & $\$ 20.5^{8}$ & $\$ 20.08$ & $\$ 20.54$ & $\$ 19.96$ & $\$ 19.89$ \\
\hline Kingston ....... & 16.88 & 15.73 & 15.79 & 18.18 & 18.53 & 18.84 \\
\hline London ... & 21.12 & 22.91 & 21.17 & 21.62 & 22.63 & 23.30 \\
\hline Ottawa & 25.23 & 25.67 & 26.67 & $39.94^{1}$ & $42.7^{1}$ & 26.36 \\
\hline Toronto........ & 34.84 & 29.44 & $33.5^{\circ}$ & 33.51 & $34 \cdot 32$ & 34.83 \\
\hline
\end{tabular}

The exemption of the personal earnings of non-householders in cities was increased from $\$ 400$ to $\$ 600$ in I $906,{ }^{2}$ and, two years later, ${ }^{3}$ the exemption of incomes from sources other than personal earnings when the gross amount does not exceed $\$ 300$ was introduced. In spite of these increased exemptions, we do not find that the proportion of the total burden of taxation borne by income has greatly decreased. The average for 1906 is four and three-tenths per cent, while that for I9II is three and seven-tenths per cent. In only two cases, Hamilton and Toronto in 1907 , do we see any substantial decrease, while in many cases there is an increase in the ratio of income to total assessment, even in years of increased exemption. The figures for I9I I show a slight falling-off, due to the further extension of exemptions in $1910^{4}$ by the raising of the free amount of personal earnings of householders in cities from $\$ 1000$ to $\$ 1200$.

$1 \$ 26.45$ and $\$ 30.5 \mathrm{I}$ for 1909 and 1910, respectively, omitting civil. service incomes.

2 6 Edward VII, c. 36, s. I.

38 Edward VII, c. 50, s. 4.

4 Io Edward VII, c. 88, s. 2. 
Owing to the fact that an increase in population does not always mean an increase in wealth, we must not lay too much stress on the amounts of taxable income per head. The figures given serve to show, however, that income assessment has not failed. Toronto in IgII had as high an assessment per capita as in 1906, in spite of the increases in exemption, while, of the other four cities, Hamilton stands alone in not showing a decided increase for these five years.

The augmentation in the Ottawa returns of 1909 was due to a decision of the Supreme Court of Canada on October 6th, I908, ${ }^{1}$ which declared that a civil or other officer of the Government of Canada may be lawfully taxed in respect to his income in the municipality in which he resides. Previous to this judgment, the incomes of Government officials had not been taxed, it having been held that such taxation was in conflict with the section of the British North America Act which gives to the Central Parliament exclusive legislative authority over the fixing of the salaries of its officers. Many objections were raised to the taxing of civil service incomes, with the result that, in 19ro, the Government came to an agreement with the city of Ottawa by which this class of incomes is exempted in return for an increase in the annual Federal grant to the city. Salaries of Dominion officials are still taxable in all other municipalities which attempt to reach income.

The figures below, giving the ratio of income assessment to that on realty and the amount of taxable income per capita for all the cities of Ontario, show the increase which took place under the new system in spite of the transfer of certain classes to the category of businesses.

140 S. C. R., 597. Follows decision of Privy Council in 1907 A. C. $8 \mathrm{r}$, Webb vs. Outrim (Australia). 
The returns for 1905 are about the same as those of the previous year owing to the time required to put the new machinery into operation. The falling-off in 1904 was due to the exemption of personal earnings having been increased from $\$ 700$ to $\$ 1000$, and the increased exemption of $1906^{1}$ is responsible for the decline in 1907.

TAXABLE INCOME IN CITIES OF ONTARIO

\begin{tabular}{|c|c|c|}
\hline Year. & Ratio to realty. & Per capita. \\
\hline r $903 \ldots \ldots \ldots \ldots \ldots \ldots$ & $3.5 \mathrm{I}$ per cent & $\$ 16.70$ \\
\hline $1904 \ldots \ldots \ldots \ldots \ldots \ldots$ & 2.88 & 13.59 \\
\hline $1905 \ldots \ldots \ldots \ldots \ldots \ldots$ & 2.94 & 13.85 \\
\hline $1906 \ldots \ldots \ldots \ldots \ldots$ & 5.04 & 24.29 \\
\hline $1907 \ldots \ldots \ldots \ldots \ldots \ldots$ & $4 \cdot 37$ & 21.44 \\
\hline
\end{tabular}

It is generally acknowledged that some evasion of the income tax provisions does occur. But the extension of the requirement placed upon corporations and employers to furnish information, so as to compel banks to give to the assessors full returns of interest paid on deposits and registrars of all mortgages to report names of mortgagors and mortgagees and all other particulars, would reduce this evasion to a minimum. ${ }^{2}$ If, after having given this plan sufficient trial, the authorities should still have difficulty in reaching the interest paid on mortgages, they might profit from the experience of New York and other states with the mortgage recording tax. ${ }^{3}$

In the cities and towns of Saskatchewan and in the

16 Edward VII, c. 36 , s. x. Cf. also supra, p. 67.

2 Suggestion of Mr. Jas. C. Forman, Assessment Commissioner of Toronto.

"Vide Robinson, C. F., "The Mortgage Recording Tax" in Political Science Quarterly for December, rgro. 
cities of Alberta we also find the income tax supplementing the taxation of lands and businesses. But these new western municipalities, with an industrial development far below that of the Ontario cities and with more or less shifting populations, are gradually relegating the taxation of incomes to a position of smaller and smaller importance. A tax, which has become necessary in the industrial cities of the east in order that all individuals who should contribute to the support of the municipality may be reached, can be omitted in the western cities without any great loss or inequality.

The provisions for the taxation of incomes in these Provinces are similar in most respects to those of Ontario, but, as is natural in communities in agricultural sections, the tax is extremely unpopular and is difficult

- to collect. In Regina, the income assessment has dwindled from $\$ 14.79$ per capita in 1906 to $\$ 3.59$ in 1910. Lethbridge had, in 1905 , a per capita income assessment of $\$ 15.09$, which fell to $\$ 5.57$ by 1909, when, owing to the difficulty of collection, the taxation of incomes was abolished. Calgary, the largest city of Alberta, began in I9II to exempt incomes. Edmonton is moving in the same direction, and, in Regina, Moose Jaw and Saskatoon, there are indications that similar steps will soon be taken. This movement away from the direct taxation of income is partly the result of the tendency in these Provinces to concentrate on the taxation of land. ${ }^{x}$

Income is taxed in Nova Scotia ${ }^{2}$ and New Brunswick under the provisions for the general property tax. In the former Province, an exemption of $\$ 600$ in towns and

1 Vide infra, chapter vii.

'Halifax does not tax income. 
$\$ 400$ in smaller municipalities is allowed, ${ }^{1}$ while in the latter the general exemption is only $\$ 200,{ }^{2}$ with $\$ 300$ in the case of certain cities. ${ }^{3}$ Merchants, in New Brunswick, are taxable for the income derived from business, after being permitted to deduct an amount equal to the interest upon the value of the stock which is taxed as personal property.

New Brunswick 4 has made an unsuccessful experiment with the capitalization of income for the purpose of assessment. Toward the year 1850 , the Legislature directed that incomes be capitalized at five per cent. This was done until $\mathrm{I} 875$, although many municipalities had already gone back to the level rate, the city of St. John having abandoned the capitalization method as early as I859. Fredericton retained the differential rate until 1907,5 when it was abolished by an almost unanimous Legislature. Many persons receiving fixed incomes were being forced to leave the city because of the tax burden, while practically all those whose incomes were less easily ascertained were escaping taxation.

Owing to the fact that neither of these Provinces has reached that stage of industrial development that is to be found in Ontario, the ascertainment of the amounts of taxable income is far less difficult than was the case under the old law in that Province. The figures below, showing the ratio of income assessment to that on real estate and the taxable income per capita for the city of

${ }^{1}$ Rev. Stat. of N. S., 1900, c. 73.

2 Consol. Stat. of N. B., 1903, c. 170.

3 Fredericton (7 Edw. VII, c. 84) and Dalhousie (3 Edw. VII, c. 73).

'See Murray, Local Govt. in Maritime Provinces, in Toronto University Studies, vol. 2.

$\checkmark 7$ Edward VII, c. 84 .

- Compiled from statistics furnished by H. E. Wardroper, city clerk. 
St. John, indicate how much greater a proportion of taxation is borne by income in this city than in the cities of Ontario. The decrease of 1909 is due to the exemption of incomes under $\$ 300$ and of $\$ 200$ of the incomes of all persons receiving more than $\$ 300$ and less than $\$ 1000$. The absence of any provision for exemption before this year and the low exemption now granted, as well as the inclusion under income of the revenue received by professional men and others, explain to a large degree the great difference in the amounts shown for this city and for the Ontario municipalities. ${ }^{\text {. }}$

TAXABLE INCOME IN ST. JOHN

\begin{tabular}{|c|c|c|}
\hline Year & Ratio to realty. & Income per capita. \\
\hline I $906 \ldots \ldots \ldots \ldots \ldots \ldots$ & 30.98 per cent & $\$ 78.12$ \\
\hline $1907 \ldots \ldots \ldots \ldots \ldots \ldots$ & 34.16 if & 87.56 \\
\hline $1908 \ldots \ldots \ldots \ldots \ldots \ldots \ldots$ & 35.69 & 93.73 \\
\hline $1909 \ldots \ldots \ldots \ldots \ldots \ldots$ & 23.02 & 63.27 \\
\hline $1910 \ldots \ldots \ldots \ldots \ldots \ldots$ & 24.37 & 68.12 \\
\hline
\end{tabular}

The Provincial Government of Prince Edward Island taxes income at the rate of one and one-half per cent $^{2}$ after freeing from taxation all incomes not exceeding $\$ 350$ and allowing a similar exemption on wages. This tax, which was first levied in 1894 at the rate of one per cent, ${ }^{3}$ applies to all incomes received by residents of the Province, regardless of source. Revenue received from farms which are subject to the land tax is not, however, liable to taxation as income. In a Province such as Prince Edward Island, with its three small counties having a total population slightly under 100,000 ,

1 Vide supra, p. 69.

22 Edward VII, c. 5.

57 Victoria, c. 2. 
and a total revenue, exclusive of the Dominion substay, of about $\$ 103,000,{ }^{x}$ the tax is not difficult of administration. The yield was $\$ 10,631$ in 1909 , or ten and threetenths per cent of the total revenue collected in the Province; in I9 10 the returns were $\$ 1 \mathrm{I}, 372$, or eleven and four one-hundredths per cent of the total revenue less the Federal subsidy. The ratio of income tax returns to the total of Provincial revenue, including the subsidy, for these two years was two and eighty-three one-liundredths per cent and three and three one-hundredths per cent, respectively. The total collected per capita in I9Io amounted to only Io.8 cents.

It is to British Columbia that we must turn for the Province in which the direct taxation of income has reached its greatest importance. From the year 1899, when less than $\$ 10,000$ was collected, to r9Io, when the yield was nearly $\$ 19 I, 000$, this tax has been gradually gaining in prominence. In 1897,2 all persons receiving incomes over $\$ 1000$ were taxed at a rate varying from one and one-fourth per cent to one and three-fourths per cent, according to amount. Four years later, ${ }^{3}$ the Legislature took a decided step in favor of progressive taxation by imposing the following rates on all incomes, after allowing an exemption of $\$ 1000$ :

Class A : Incomes of $\$ 1,000$ to $\$ 10,000,1 / 2$ per cent up to $\$ 5,000$ and $21 / 2$ per cent on the remainder.

Class B: Incomes of $\$ 10,000$ to $\$ 20,000,21 / 2$ per cent up to $\$ 10, c 00$ and 3 per cent on the remainder.

Class C: Incomes of $\$ 20,000$ to $\$ 40,000,3$ per cent up to $\$ 20,000$ and $31 / 2$ per cent on the remainder.

Class D : Incomes of over $\$ 40, c c 0,31 / 2$ per cent up to $\$ 40, c c 0$ and 4 per cent on the remainder.

1 Year ending Sept. 3oth, I9ro.

2 Revised Statutes, c. 179.

64 Victoria, c. 38 (1901). 
A reduction of one-half of one per cent throughout the schedule was granted if the tax was paid before June 30 th of each year. In $1903^{1}$ these rates were changed by the removal of Class $\mathrm{D}$, and by causing Class $\mathrm{C}$ to embrace all incomes over $\$ 20,000$. It was also provided that the discount for prompt payment should be ten per cent of the amount of the tax.

In $1905,{ }^{2}$ following the report of a special assessment commission which recommended the substitution of an income tax for the tax on personal property, the rates were raised, and it was provided that where an income is derived from personal property the taxes on both personalty and income are not to be paid but only that tax which is the greater. Thus an important step has been taken in the direction recommended by the commission. The rates fixed in 1905 were as follows:

Class A: On all taxable income up to and including $\$ 2,000 \ldots \ldots$ I 1 1 2 per cent Class B: On all taxable income when the income exceeds $\$ 2, c c 0$ but is less than $\$ 3,000 \ldots \ldots \ldots \ldots \ldots \ldots \ldots \ldots 13 / 4$ "

Class C: On all taxable income when the income exceeds $\$ 3,000$ but is less than $\$ 4,000 \ldots \ldots \ldots \ldots \ldots \ldots \ldots \ldots, 2$ "

Class D: On all taxable income when the income exceeds $\$ 4,000$ but is less than $\$ 7,000 \ldots \ldots \ldots \ldots \ldots \ldots \ldots \ldots, 3 \ldots \ldots \ldots$

Class E: On all taxable income over $\$ 7,000 \ldots \ldots \ldots \ldots \ldots \ldots 4$ "

The exemption of $\$ 1000$ and the discount of ro per cent for prompt payment were continued in this act. These rates were reduced in 1910. ${ }^{3}$ Class A now pays one per cent, B one and one-fourth per cent, $\mathrm{C}$ one and one-half per cent, $\mathrm{D}$ two per cent and $\mathrm{E}$ two and onehalf per cent. This reduction, along with that in the rates on realty and personalty, is due to the surplus in the Provincial finances.

${ }^{1} 3$ and 4 Edward VII, c. 53 .

' 5 Edward VII, c. 50.

- Io Edward VII, c. 47 , s. 4 . 
As a revenue producer, the British Columbia income tax has proved quite satisfactory. The yield per capita in 1900-1901 was \$.158, while the figures for I909-10 show a return of $\$ .52 \mathrm{I}$ per capita. This amount, however, includes the taxes on banks and other corporations which were introduced in I901. ${ }^{x}$ When we compare the returns from the income tax with the total revenue of the Province for the year I9Io, we see that only two and sixteen-hundredths per cent of the revenue is produced from this source, or about two and three-tenths per cent of the revenue exclusive of the amount received from the Dominion. The income tax ranks ninth on the list if we range the sources of revenue for I9Io (excluding the Federal subsidy) according to the amount yielded, and fifth among the sources which properly may be called taxes.

In the matter of the prevention of double taxation of income by the several authorities, there is room for great improvement. This condition of affairs is all the more surprising when we see the care taken to avoid the double taxation of property and income, or of income received from corporation stock and that of the corporation itself. Section 12 of the Ontario Assessment Act ${ }^{2}$ provides that every person assessable for income shall be so assessed in the municipality in which he resides. The section following declares that income in the control of an agent of a person residing out of the Province is assessable against the agent. Here we have the principles of residence and situs in direct conflict. Another example of such lack of scientific division may be taken

1 I Edward VII, c. 56. Cf. 3-4 Edward VII, c. 53, and infra chapter on Corporation Taxes.

${ }_{4}^{4}$ Edward VII, c. 23 and amendment; 7 Edward VII, c. 46, 
from the British Columbia Assessment Act, ${ }^{2}$ where it is provided that income derived from a source outside the Province is to be taxed if it is used in the Province. It then proceeds to state that no deduction is to be made from income for any interest on borrowed capital from which the income is derived, when such interest is paid to a lender who does not transact business in the Province and who does not pay taxes thereon in the Province. Here again we have a conflict between the principle of taxing all income at the residence of the recipient and that of reaching it at its source.

It is true that the second provision mentioned in the case of British Columbia tends to prevent the creation of fictitious debts for the purpose of evading taxation. But, if the principle of situs were followed throughout, such preventive legislation would not be necessary, since the interest on loans would be taxable where the capital is invested by the borrower. This principle should be generally adopted, not only because it is extremely difficult to reach the incomes of residents which have been earned outside the jurisdiction of the taxing authority, but also because that authority in whose jurisdiction the income is earned has first claim on it for the purpose of taxation.

It has been said that we cannot abandon altogether the benefit theory of taxation, that the individual owes something to the community in which he resides. But he pays this debt in his real estate tax, if he is a landholder, or in enabling others to pay this realty tax if he is a tenant. In following the principle of situs we combine the ability theory and the benefit theory of taxation. Both the ability of the individual to contribute to

13-4 Edward VII, c. 53. 
the support of a community and the benefit he receives from the community may be measured by the amount of revenue he receives within its jurisdiction. Let benefit enter in to designate the authority to which the tax is to be paid, while ability shall determine the amount payable. There is no good reason for taxing a person for the privilege of spending his income. All public authorities should welcome persons whose expenditures will increase the prosperity of the community, even when they will pay no taxes directly.

The principle of situs in the taxing of income removes a great deal of the difficulty of collection by making possible taxation at the source. It is true that we can not have progressive taxation under such a system because income is not entered against the recipient in a lump sum. But progressive income taxes have never been highly successful in democratic countries. The problem is rather one of finding means of reaching income. 


\section{CHAPTER VII}

\section{Taxes on Real Estate}

\section{THE EXEMPTION OF IMPROVEMENTS}

AN important phase of land taxation in Canada is the exemption of improvements in the western Provinces. In this section of the country, where land is the chief form of wealth, we find the nearest approach in Canada to the single tax. The rapid development of the Canadian west during the last decade or two has attracted land speculators and it is felt that a concentration upon the taxation of land without regard to improvements will tend to force owners to build or to sell to those who will.

In British Columbia the council of any municipality was authorized as early as $189 I^{1}$ to exempt fifty per cent or all of the value of improvements on land. The Municipal Act of $1892^{2}$ expressly stated that improvements should not be assessed at more than fifty per cent of their actual value and permitted the exemption of a still greater percentage or of the full value. These provisions are still in force, ${ }^{3}$ having been reënacted in the Municipal Clauses Act of 1906.

Vancouver, which had been organized under special charter and which was not, therefore, included in the

${ }^{1}$ See article by L. S. Dickey, in Single Tax Review, May-June, I9I I, p. 59. There is in this number a description of Vancouver's system as seen by those who favor the single tax on land.

2 Ibid., p. 60.

Vide 6 Edward VII, c. 32, s. I29. 
Municipal Act of 1892 , began to exempt fifty per cent of the value of improvements in I895. After an experiment of ten years with a fifty per cent exemption, the council of this city decided, in 1906, to decrease the taxable proportion of improvements, making it only twentyfive per cent. Early in I9Io it was decided to exempt all improvements from taxation.

Vancouver now receives the larger part of its revenue from a two and two-tenths per cent tax on the unimproved value of land. We can not, however, apply the term "single tax" to this system, for, in addition to the municipal license taxes on business places and the poll tax, there are collected, within the city, the Provincial taxes on personal property and on income. That these two sources of revenue are reserved for the use of the Provincial Government does not affect the taxpayer, who is compelled to pay a tax on his personalty or on his income or both, as well as on his land, in addition to the indirect taxes paid to the Federal Government.

The "single tax" was one of the planks in the platform of Mayor L. D. Taylor in the election of I9ro and again in I9II. That this platform, which meant nothing more than the total exemption of improvements which, from 1906 to I9I0, had been assessed at only twenty-five per cent of their value, was favorably received by the voters was due to the fact that the phenomenal increase in land values made it possible to effect the change without altering the tax rate. In $1905{ }^{,}$the last year of the fifty per cent exemption, the assessed value of lands increased fifty per cent; in 1906, fifty-two per cent. The gain for the three years, 1906-07-08, totaled about ninety-two per cent. In I 909 the gain was nearly sixty

${ }^{1}$ For statistics, vide Single Tax Review, May-June, Igr I, p. 3. 
per cent, and in I9IO, the first year of the complete exemption, twenty-eight per cent. These increases have enabled the city to derive a greater revenue from the real estate tax, in spite of the increased exemptions and the unchanged tax rate.

According to Mayor Taylor, ${ }^{1}$ the assessed value of improvements in the city has increased from about $\$ 200$ per capita in 1895 to $\$ 284$ in 1905 and $\$ 308$ in 1909 , and more substantial buildings have been erected since 1906 . Figures given in the "Vancouver Number" of the Single Tax Review ${ }^{2}$ show that the assessed value of land decreased during the three years preceding 1895 , when the fifty per cent exemption began, while that of improvements increased. The same is true of the six years immediately following the change in the system, and for the three years 1902-03-04, the increase in land values and improvement values was about equal,

The figures below, giving the values of real property (exclusive of improvements) and of improvements, and the ratio of the latter to the former, show a gradual increase in the proportionate value of improvements until the year 1904, when the rapid increase in population caused a sudden advance in real estate values which brought about a decline in this ratio. Improvement values have not, therefore, kept pace with land values, nor do the changes in the ratios bear any ascertainable relation to the changes in the tax system.

The population of Vancouver has been trebled during the past five or six years, and there is everything to indicate that this city will continue to grow both in numbers and in prosperity. But it is difficult to find any

1Vide article in Single Tax Review, May-June, I911, p. 12.

Ibid., p. 3. 
LAND AND IMPROVEMENT VALUES IN VANCOUVER

\begin{tabular}{|c|c|c|c|}
\hline Year. & Land assessment. & Improvement values. & Ratio. \\
\hline & & & Per cent \\
\hline $1895 \ldots \ldots \ldots \ldots \ldots$ & $\$ 13,829,724$ & $\$ 4,317,660$ & $3 \mathrm{r} .2$ \\
\hline $1896 \ldots \ldots \ldots \ldots \ldots$ & I $3,109,394$ & $4,278,680$ & 32.6 \\
\hline $1897 \ldots \ldots \ldots \ldots \ldots$ & $13,000,869$ & $4,441,490$ & 34.1 \\
\hline $1898 \ldots \ldots \ldots \ldots \ldots$ & $12,672,649$ & $4,551,740$ & 35.9 \\
\hline $1899 \ldots \ldots \ldots \ldots \ldots$ & $12,705,099$ & $5,011,190$ & 39.4 \\
\hline $1900 \ldots \ldots \ldots \ldots \ldots$ & I $2,826,905$ & $6,726,740$ & 52.4 \\
\hline rgor ................... & $12,792,530$ & $7,440,600$ & $58 . i$ \\
\hline $1902 \ldots \ldots \ldots \ldots \ldots$ & $12,842,150$ & $8,223,220$ & 64.0 \\
\hline $1903 \ldots \ldots \ldots \ldots \ldots$ & $13,845,565$ & $9,091,270$ & 65.6 \\
\hline $190_{4}, \ldots \ldots \ldots \ldots \ldots$ & $14,440,935$ & $10,247,920$ & 70.9 \\
\hline $1905 \ldots \ldots \ldots \ldots \ldots$ & $16,739,640$ & $11,804,250$ & 70.5 \\
\hline $1906 . . . \ldots \ldots \ldots \ldots$ & $25,101,760$ & $14,087,640$ & 56.1 \\
\hline $1907 \ldots \ldots \ldots \ldots \ldots$ & $38,346,335$ & $16,381,475$ & 42.7 \\
\hline $1908 \ldots \ldots \ldots \ldots \ldots$ & $41,641,870$ & $20,127,035$ & 48.3 \\
\hline $1909 \ldots \ldots \ldots \ldots \ldots$ & $48,281,330$ & $24,405,210$ & 50.5 \\
\hline $1910 . . . \ldots \ldots \ldots \ldots$ & $76,927,720$ & $29,604,755$ & 38.4 \\
\hline $1911 \ldots \ldots \ldots \ldots \ldots$ & $98,777,785$ & $37,845,260$ & 38.3 \\
\hline
\end{tabular}

connection between the so-called single tax system and

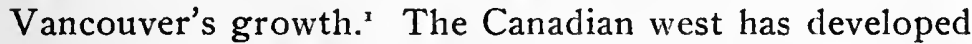
most rapidly during the last decade and Vancouver is not alone in its sudden rise from a small city to one of some importance. Vancouver is advantageously situated, and, with the opening-up of the west and the entry of new railways into the city, growth is to be expected. A sudden increase in building operations, and especially the construction of modern apartment and office buildings, is quite natural in a city which has rapidly reached and passed the roo,00o mark. It is this abnormal growth which makes it impossible to estimate the effect of the exemption of improvements.

The city of Nanaimo also exempts improvements, and

1 See F. C. Wade, The Single Tax Humbug in Vancouver, Vancouver, 1912, who compares Vancouver with the non "single tax" cities, showing that they have increased still faster. 
the voters of Victoria and New Westminster in January, I9II, and April, I9II, respectively, decided to change from the taxation of fifty per cent of improvements to complete exemption. Land values in Victoria have more than doubled in the four years 1907 to 1910 , but the assessed value of improvements has not increased in equal proportion. In the former year, improvement values equaled fifty-nine and nine-tenths per cent of the assessed value of land, while the ratio for Igro is only forty-four and one-tenth per cent. New Westminster ${ }^{x}$ has a population of about 15,000 . Its land assessment for I9Io was $\$ 8,496,575$ and the assessed value of improvements $\$ 2,402,780$, or twenty-eight and two-tenths per cent of the land value.

British Columbia has about fifty municipalities, none of which tax more than fifty per cent of the assessed value of improvements and many of which exempt improvements. This is true of all the important cities, as we have seen, and of a large number of the rural municipalities. In the latter, improvements form a very small part of the assessed property and the exemption is not felt by the landowners. South Vancouver, ${ }^{2}$ a suburb of the city of Vancouver, had, in I909, an assessed value of improvements which was only fifteen and eight-tenths per cent of that of land. This ratio decreased in I9Io to twelve and three-tenths per cent, and in IgI to eight and two-tenths. This municipality has exempted improvements since I903. Burnaby, ${ }^{3}$ which also adjoins Vancouver, has never taxed improvements. ${ }^{4}$ The land assessment in 1910 totaled $\$ 10,324,610$, while that on

1 Single Tax Review, op. cit., p. II.
'Ibid., p. 6.
IIbid., pp. 9-I0.
4 Organized I892. 
improvements was only $\$ 744,905$, or seven and twotenths per cent of the former. The ratios of improvement values to land values in rural municipalities situated farther from the cities are probably still lower.

The Municipal Clauses Act of $1906^{\times}$authorizes the taxation of "wild lands" up to four per cent of their value. This is the rate imposed by the Provincial Government $^{2}$ on wild lands lying outside the municipalities, and it thus becomes possible for the councils of rural corporations to continue to discriminate in favor of improved lands upon the organization of such municipalities from the districts subject to the Provincial tax.

Alberta and Saskatchewan are the other two Provinces which the single-taxers claim for their own. In the former, Edmonton has not taxed improvements since $1904^{3}$ and Strathcona began to exempt this class of property in 1907.4 Calgary taxes improvements on land at their full value, but has just applied to the Legislature for permission to tax buildings at fifty per cent of their assessment. ${ }^{5}$ In the city of Lethbridge only twenty per cent of the value of improvements is exempted, ${ }^{6}$ but all vacant lands in the business section of the city are super-assessed fifty per cent. The principle here followed is to strike directly at the speculators without increasing the tax burden of the landowners generally.

${ }^{16}$ Edward VII, c. 32.

2 Vide supra, p. 29.

${ }^{3}$ Chapter I9, Ord. of N. W. T., I904.

4 Edward VII, c. 34 .

${ }^{5}$ In Feb., I9r2, the council of Calgary reduced the assessment on buildings to $25 \%$ of their actual value.

- In 1912, Lethbridge will exempt $33 \frac{1}{3} \%$ of the value of improvements. 
The cities and towns of Saskatchewan ${ }^{x}$ tax improvements at sixty per cent of their value. At the IgI I session of the Legislature, however, a measure ${ }^{2}$ was passed retaining this percentage as the maximum amount taxable, but permitting a gradual reduction at a rate not to exceed fifteen per cent of the value of improvements per annum. There is every likelihood that in 1915 most of the cities and towns of this Province will have adopted the "Edmonton system."

The table below shows the ratios of improvement values to the values of real estate so far as these could be ascertained from correspondence with the officials of the cities of these two Provinces. Edmonton and Strathcona have no records of the value of improvements. Calgary, with its taxation of buildings at full value, has not only maintained its ratio, but actually shows a slight increase. In Lethbridge, which imposes the fifty per cent super-assessmient, there is a considerable increase in the proportionate value of improvements. Too much stress, however, should not be laid on the tax system in examining the reasons for the growth of the cities of these Provinces, for they are situated in the heart of the Canadian wheat country and are advancing rapidly because of their commercial relations with the surrounding territory.

The cities of both Provinces are limited to a maximum tax rate of two per cent, the towns of Saskatchewan to one per cent, exclusive of the school and local improvement rates. In 1906, Edmonton's general rate was only seven and one-fourth mills.

Both Alberta and Saskatchewan, in their respective

18 Edward VII, cc. 16 and 17.

2 I George V, c. I8, s. I5, and c. I9, s. I7. 
RATIOS OF IMPROVEMENTS TO LAND VALUES

\begin{tabular}{|c|c|c|c|c|c|}
\hline & 1907 & 1908 & 1909 & 1910 & I9II \\
\hline Calgary $\ldots . . . \ldots \ldots \ldots$ & $\begin{array}{c}\text { Per cent } \\
33.3\end{array}$ & $\begin{array}{c}\text { Per cent } \\
31.9\end{array}$ & $\begin{array}{c}\text { Per cent } \\
33.3\end{array}$ & $\begin{array}{c}\text { Per cent } \\
34.7\end{array}$ & $\begin{array}{c}\text { Per cent } \\
34.2\end{array}$ \\
\hline Lethbridge ............ & 54.8 & $5^{1.2}$ & $5^{1.6}$ & 64.0 & 74.4 \\
\hline Regina ................ & $\cdots$ & $\cdots$ & 34.9 & 36.0 & $\ldots$ \\
\hline Moose Jaw .................. & .... & $\cdots$ & 52.3 & 57.2 & $\cdots$ \\
\hline Saskatọon .............. & ... & ... & 25.0 & 23.7 & $\cdots$ \\
\hline
\end{tabular}

village acts, ${ }^{,}$reënacted the clauses in the Village Ordinance of the Northwest Territories, which provided for local option in the exemption of improvements and of all taxable property except land. In the former Province, upon presentation of a resolution passed by the council of the village and a petition signed by two-thirds of the total number of ratepayers, the Minister of Public Works may order that the assessment in the village be limited to one based upon the actual value of all lands exclusive of improvements. Should any village desire to return to the taxation of improvements, it must again apply to the Minister of Public Works. In Saskatchewan, the village council may limit the assessment to lands upon presentation of a petition signed by twothirds of the total number of resident electors and without application to the Provincial authorities. The council of any village which has exempted improvements may repeal a by-law providing for such exemption upon petition of a like number of electors. The assessment will

' Alberta, 1907, c. 10, s. 52; Sask., 1906, c. 35 , s. 4, and 1908, c. 18, s. $18 \mathrm{I}$. 
then be on all the real and personal property and income in the village.

Alberta $^{x}$ now has sixteen out of about fifty villages which have gone over to the "single tax" system. Saskatchewan, ${ }^{x}$ with a total of 185 villages, has only about twenty which have exempted all property other than land. No village which has adopted this "single tax" has returned to the taxation of property in other forms, except in those cases where villages have been created towns. In both Provinces, new villages are continually being established and villages are growing into towns.

Mr. J. W. Bayne, Deputy Minister of Municipal Affairs for Saskatchewan, in his report for the financial year 1909-10, ${ }^{2}$ states that for two years there had been "practically no application" for the adoption of the system by the villages of the Province. "Some villages," he says, "object to the system ... since it exempts from taxation elevators erected on certain railway grounds." Since the date of the above report, however, nine villages have chosen the so-called single tax system.

Generally speaking, those villages which have concentrated on the taxation of land are well satisfied with the new system, and its adoption would be more rapid were it not that most of the villages have a large number of residents who are holding lands for speculation. In many of the villages the "town sites" are owned by the railways and others, and the residents eagerly grasp the opportunity to make these large holders contribute as large a share as possible toward the village expenses. No great check, however, is placed upon speculation by

1 June, IgIr.

2 Feb. 28, 1910; there were then only II villages using this system. 
this system, since the expenditure of the villages is small and the rates low. The total annual receipts in the several villages of the two Provinces range as low as from $\$ 1000$ to $\$ 2000$. The value of improvements and of taxable personal property and income is very small in proportion to that of lands, and the increased burden under the new system is felt only by the largest holders. The maximum rate in villages which tax all property is one per cent. The maximum in Alberta for "single tax" villages is two per cent, and in Saskatchewan it has just been raised from two and one-half to four per cent. $^{2}$

In the r9I0-I I session of the Saskatchewan Legislature, the Rural Municipality Act and the Local Improvement Act were amended so as to permit the local councils to levy a percentage rate on the value of lands exclusive of improvements, instead of a flat rate per acre. ${ }^{2}$ The change may be introduced either by a two-thirds vote of the council or by a petition signed by one-half the resident ratepayers of the municipality. The new system will become permanent after such a petition has been presented for two successive years, and the council can then revert to the old method only upon presentation of a similar petition demanding the change. The maximum rate on the adoption of this ad valorem system is to be four per cent as in the case of the "single tax" villages. ${ }^{3}$ These provisions make it possible for a local improvement district or a rural municipality to become a village without changing its tax system. As a move in the direction of the single tax they are unimportant, since im-

${ }^{1}$ I George V, c. 20.

Vide I George V, c. 2I, s. 25, and c. 22, s. 8.

${ }^{3}$ Section 7 of c. 22 increases the rate for Local Improvement Districts from $I \frac{I}{4} \mathrm{c}$. to $5 \mathrm{c}$. per acre to $2 \mathrm{I} / 2 \mathrm{c}$. to $6 \mathrm{t} / 4 \mathrm{c}$. per acre. 
provements have never been taxed in these local organizations.

Single tax propagandists are making a great deal of the exemption of improvements in the Canadian west and are crediting themselves with the "success" of the experiment. Their doctrines have had some influence on the inception and growth of the movement, ${ }^{x}$ but absentee ownership has been, and still is, the great stimulus toward the concentration of taxation on land values. The above survey shows that land is the sole taxable class of property only in the rural districts of Alberta and Saskatchewan. The urban municipalities of all three Provinces have other forms of taxation, such as the business and income tax or the personal property tax. ${ }^{2}$ The term "single tax" as applied to these is, therefore, a misnomer.

The exemption of improvements affects agricultural districts only in the villages, rural municipalities and local improvement districts of the two prairie Provinces and in the rural municipalities of British Columbia. We have seen that the ratio of the value of improvements, which term is interpreted so as to apply only to buildings, to that of land is very small in these rural districts. The partial or complete exemption of the former can, therefore, have little effect.

The general conclusion regarding the exemption of improvements in the cities and towns of the three Provinces is that, while the construction of a better class of buildings has been encouraged, the rate of taxation is too low effectively to prevent speculation. It is also this low rate of taxation that has kept the taxpayers fav-

1 Vide Single Tax Reviezw, May-June, I911, p. 56.

2 This is Provincial in B-itish Columbia. 
orable to the system. A considerable increase in the tax rate would undoubtedly lead to a reversion to the taxation of improvements. Such an increase, however, is not likely to occur so long as the "boom" period, which now prevails throughout the Canadian west, continues. But, as soon as the cities of this section have settled down to a normal expansion and speculation has disappeared, land values will return to normal. The taxpayers will then have to choose between a high rate on land alone and a moderate one on land and improvements. 


\section{CHAPTER VIII}

\section{Taxes On Real Estate}

\section{A.-ASSESSORS AND VALUATION}

In the main, Canadian municipalities have kept their local affairs free from party politics, thus tending to bring about good government by preventing a crystallization of votes on issues which have little relation to local needs and, to a large extent, by eliminating partisanship. The absence of the latter may be seen in the work of the tax assessors. Favoritism shown by assessors to their political partisans, an evil which has become familiar to Americans, is not found in the Canadian assessments. The assessors owe their appointments to no political party and are under obligations to no section of the community in which they perform their duties. They are completely outside of politics. In the United States, both election and appointment of assessors have been tried, with little difference in result. Tightly drawn party lines and the "spoils system" have not been conducive to impartial valuations. The assessments in Canada are not absolutely free from abuse, but the contrast with those in the American states is strong.

No great divergence in methods of appraising real estate for taxation purposes is to be found in the Canadian Provinces. Upper Canada (Ontario) followed the English custom of levying the rate on the rental value until the year 1866 , when the capital value was made the basis of assessment, the latter method con- 
forming more closely to local conditions. At present, the only example of the old method is found in the city of Quebec, where a rate of seventeen and one-half per cent is levied on the rental value of real estate.

The Ontario Act of $1866^{\mathrm{I}}$ enacted that real property should be assessed at its "actual cash value" as it "would be appraised in payment of a just debt from a solvent debtor." Evidence taken by the special commission of I900 showed that the latter part of this clause is unnecessary and introduces confusion in the work of the assessors. It was repealed in $1904,{ }^{2}$ and the ascertainment of the "actual cash value" is now left to the assessors. This is also the practice in the other Provinces, with the exception of Alberta and Saskatchewan, which, in some instances, endeavor to instruct their assessors in the methods to be followed. In the cities of these Provinces, ${ }^{3}$ the assessors, in estimating the value of real estate, are required to have regard to its situation and the purpose for which it is used, or, if sold by the present owner, it could and probably would be used in the next succeeding twelve months.

In $1866^{4}$ the Upper Canada Assessment Act provided that,

in assessing vacant ground or ground used as a farm, garden or nursery, and not in immediate demand for building purposes in cities, towns or villages, whether incorporated or not, the value of such vacant or other ground shall be that at which sales of it can be freely made, and, where no sales

1 29-30 Victoria, c. 53, s. 40.

${ }^{2} 4$ Edward VII, c. 23 , s. 36.

3 Alberta, 1907, c. 34 ; Saskatchewan, I908, c. 16, s. 20.

29-30 Victoria, c. 53 
can be reasonably expected during the current year, the assessors shall value such land as though it was held for farming or gardening purposes, with such percentage added thereto as the situation of the land may reasonably call for.

This clause remained in force until $1880 .^{x}$ Between this year and $1895,{ }^{2}$ the assessors were permitted to value vacant lands as farm lands only when the local council so directed. At present this is done only when the extent of such lands exceeds fifty acres ${ }^{3}$ in cities and ten acres in towns and villages. The Legislature, by thus prescribing a minimum area, has removed the aid to land speculators which was furnished under the older provisions.

The Ontario Legislature, following the Manitoba and British Columbia practice, ${ }^{4}$ provided in $1904^{5}$ for the separate valuation of lands and buildings, in the hope that this would aid the assessors in arriving at an equitable assessment. That this method has tended to bring about greater accuracy in the work of the assessors is the general opinion of the local tax commissioners of Ontario as well as of the tax officials of Manitoba and British Columbia. It makes possible a close comparison of land values, which can not be reached when the whole property, land and improvements, is valued as a unit.

Before the passage of the Ontario Assessment Amending Act of $1901,{ }^{6}$ the assessors in the cities and towns of

${ }^{1} 43$ Victoria, c. 27 , s. 7 .

${ }^{2} 58$ Victoria, c. 47 , s. 2.

${ }^{3}$ Raised from 2 acres by 7 Edward VII, c. 4 I, s. 6.

"Manitoba Revised Statutes, 1902, c. I17, s. I3; British Columbia Statutes, 6 Edward VII, c. 32, s. II4.

${ }^{6} 4$ Edward VII, c. 23, s. 36 (2).

6 I Edward VII, c. 29. 
that Province were required to assess all real property in the ward in which it lay. The courts held ${ }^{x}$ that, under this provision, the rails, poles and wires of the Toronto Street Railway Company must be assessed in the ward in which they were situated and must be treated as so much dead material and not as necessary portions of a going concern. This decision led to the "scrap iron assessment." A partial remedy was introduced in I90I when such real property was made assessable in any one ward of a city or town. But no authority was given for the valuation of the property in connection with a franchise ${ }^{2}$ until $1902,{ }^{3}$ when provision was made for the assessment of "lands" ${ }_{4}$ of heat, light, power and other companies using the streets of a municipality in the ward in which the head office ${ }^{5}$ of such company is situated and as part of a "going concern."

In all the Provinces, the assessors may require ratepayers to furnish statements of taxable property, which, however, are not binding on the former. There is usually a penalty imposed for the rendering of a false statement, and appeal may be had by the taxpayer first to the local council or board of revision, and then to the county courts.

\section{B.-EXEMPTIONS}

The Canadian Provinces make the customary provisions for the exemption of property used for educational, charitable and religious purposes, The three western

125 A. R., 35I (1900) ; cf. also 27 S. C. R., 453 (1897).

${ }^{2}$ Ontario L. R., 62 (1902).

32 Edward VII, c. 3 I.

427 S. C. R., 453, held that gas pipes, electric poles, etc., are realty for the purpose of assessment.

- If the head office is not in the municipality, the assessment may be in any ward thereof. 
Provinces, British Columbia, Alberta and Saskatchewan,. place certain limitations upon the amounts of property which may be so exempted from taxation. In the first of these, the Municipal Clauses Act ${ }^{x}$ provides that the maximum exemption for hospitals shall be 20 acres when public and 3 acres when private, and for orphan asylums, 5 acres of land actually surrounding the buildings of the institution.

Alberta and Saskatchewan, following the policy of the Northwest Territories, ${ }^{2}$ go a step farther in limiting these exemptions by applying the limitations to schools, churches and cemeteries. The Alberta Educational Tax Act $^{3}$ exempts church lands to the extent of one acre when such land is occupied by the church building; the maximum exemption of land used for cemeteries is 25 acres. The "Local Improvement Districts" in both Provinces ${ }^{4}$ also exempt up to these maxima and add a maximum of two acres for land belonging to any public or separate school. The villages of these Provinces exempt only one-half acre of church lands, except such lands as may have other church buildings erected thereon. ${ }^{5}$ Similar limitations are to be found in the cities of both Provinces and full liability for special assessment for local improvements is added to the limited exemption.

It would be well for the Province of Quebec if such limitations could be introduced within its borders. There are throughout the Province well-preserved

1 Ig06, c. 32.

'Vide Northwest Territory Consol. Ord. (1898), c. 70, and Ordinances of I90I, c 25 .

s 1907 , c. 18.

4 Alberta, I907, c. II; Saskatchewan, I906, c. 36.

${ }^{5}$ Alberta, I907, c. Io, s. 38 ; Saskatchewan, I908, c. I8, s. I79. 
relics of the French Régime in the form of vast areas of land held by the Roman Catholic Church or by its monastic orders. Within the city limits of Montreal, there are acres upon acres of land, utilized as orchards and gardens or lying idle, upon which no taxes are paid. One order, in particular, has derived, and is still receiv ing, vast revenues from the lands granted by the French king, revenues in which the public authorities have no share.

Mr. William Robb, City Treasurer of Montreal, in October, 1904, made a special report in which he recommended, among other things, that exemptions be curtailed to three times the area occupied by buildings, and that, if any exempt land be sold, a sum should be paid to the city equal to the full amount of the taxes for the time held. No action was taken on these recommendations. Nor is it probable that these abuses will be remedied in the near future, for the strength of the Roman Catholic Church in Canada is greater now than at any time since the British occupation.

In 1908, the Legislature limited the exemption of parsonages in Montreal, when not attached to the church property, to $\$ 15,000$. This change was made because of the passing of a valuable property on the city's finest residential street to a clergyman. Under the old law, the whole property became exempt and the city lost considerable revenue. The Catholic clergy, however, are not affected, since the priests' residences are always connected with the churches.

The only excuse for the exemption of the property of educational, charitable and religious institutions is that a large number of them never would be organized were they to be made subject to taxation. But this exemption should be limited to the amount actually needed for 
the carrying-on of the work of such organizations. ${ }^{x}$ No body of persons, whether religious, philanthropic or educational, should be permitted to hold lands for speculation without making any contribution to the community. Mr. Robb's recommendation regarding the payment of back taxes upon the sale of exempted lands would attain the desired end.

\section{C.-SPECIAL ASSESSMENTS FOR LOCAL IMPROVEMENTS}

Upper Canada's first complete municipal act ${ }^{2}$ made provision for special assessments for local improvements. The councils of cities and towns ${ }^{3}$ were empowered to assess

the proprietors of such real property ... as may be immediately benefited by such improvements, for such sum or sums as may at any time be necessary to defray the expense of making or repairing any common sewer, drain, flagging, posts or pavements in any public highway, street, square or place immediately opposite or near to such real property.

It is important to note that the whole expense of the improvement could be assessed on the landowners and that the assessment applied to repairs as well as to new construction. Upon the petition of at least two-thirds of the freeholders or householders in any street, lane or other public highway, the councils were also permitted to defray the expense of sweeping and watering such public highway or square "by means of a special rate to

${ }^{1}$ Two Baptist congregations in Toronto annually send in their taxes to the city tr sasurer, it being their opinion that all lands should contribute.

2 I2 Victoria, c. 8I; the Baldwin Act.

8 Sections $8 \mathrm{r}$ and $\mathrm{IC}$. 
be assessed equally on the whole rateable property in such street, square, alley or lane."

An act passed in $1853^{x}$ authorized township and county councils to tax particular sections for special purposes upon application of two-thirds of the freeholders of such section representing one-half the property value, such tax to be sufficient to defray the cost of the public improvement. Cities and towns ${ }^{2}$ were also given permission to levy a special rate for lighting on property in any particular district upon petition of a similar proportion of the residents. Five years later, ${ }^{3}$ townships were authorized to make special assessments for drainage when requested by a majority of resident owners. ${ }^{4}$

In $1859,{ }^{5}$ general provision was made for the carrying out of local improvements in cities by special assessment upon petition of two-thirds of the freeholders representing one-half the property value. In case the contemplated improvement was the construction of a common sewer having a sectional area of more than four feet, one-third of the cost was to be provided for by the council of the city. The improvement once made was to be kept in repair at the expense of the city generally.

Municipal councils were authorized in $1885^{6}$ to assume part of the cost of a special improvement whenever it should appear that inequality would result from the levying of the total cost of such improvement, and also to tax

${ }^{1}$ I6 Victoria, c. 18I, s. 9.

2 Ibid., section 15 .

322 Victoria, c. 99 ( 1858 ).

4 In cities and towns, the councils were empowered to fix an annual rent for drainage, the payment of which was to continue during the time the property was drained into any common sewer.

${ }^{5} 22$ Victoria, c. 40.

${ }^{6} 48$ Victoria, c. 39 , ss. 33 and 34 . 
other than the abutting property whenever such property has been benefited by the improvement. Two years later, ${ }^{3}$ provision was made by which a municipal council could assume part of the cost of the construction of bridges and culverts, the corporation's share not to exceed one-half, whenever such improvement benefited the municipality at large. The act of $1894^{2}$ permitted councils to provide forty per cent of the cost of permanent sidewalks, and that of $1895^{3}$ exempted the property liable for the other sixty per cent from the general rate levied for the same purpose. An amendment of $1899^{4}$ authorized the local councils to alter this percentage by a three-fourths vote.

The Ontario Municipal Act now in force ${ }^{5}$ provides that the council of every township, city, town or incorporated village may pass by-laws for the purpose of effecting local improvements, the whole or a part of the cost of which it proposes to assess upon the real property especially benefited. These local improvements may include the construction of pavements, sidewalks, sewers and bridges, the laying-out of parks and boulevards, and the construction or extension of water, gas or electric light works when the system is owned by the municipality. To the local council is left the determining of the real property benefited by the improvement, the proportion of the total cost to be borne by such property, the distribution of this proportion among the various parcels of real estate benefited, and the number of annual special

150 Victoria, c. 29 , s. 43.

57 Victoria, c. 50, s. I6.

${ }^{3} 58$ Victoria, c. 42 , s. 33 .

42 Victoria, c. 26, s. 43.

53 Edward VII, c. 19, ss. 664 to 694 and amendments. 
assessments which will be imposed. It is also empowered to make provision for the commutation of the annual assessment by a cash payment. These provisions do not apply to any work of ordinary repair or maintenance, it being expressly stipulated that all improvements constructed by special assessment must be kept in repair at the general expense during the estimated lifetime of such improvements.

Three modes of initiating local improvement works are provided for. First, the council may carry out the improvement upon receiving a petition from at least twothirds of the owners of the property to be benefited, representing at least one-half the value of such real property. Second, the council, by a two-thirds vote, may construct drains or sewers as a local improvement when considered necessary on sanitary grounds. Third, the council of a municipality may undertake any improvement provided for under the local improvement clauses, and may assess the cost thereof on the properties benefited, unless ${ }^{x}$ the majority of the owners of such real property, representing at least one-half the value thereof, petition the council against the same within one month after the last publication of a notice of the intention of the council to undertake the work. In case such petition be presented to the council, no second notice for the same improvement may be given by the council within two years after such presentation. ${ }^{2}$

Section 682 of the Municipal Act provides that the

1 This does not apply to parks and boulevards; section 673, paragraph 7 (a).

- Except when, in the case of paving, certain changes have been made in the proposed work (Sec. 669, par. 2). By section 675, municipalities may construct certain works, such as paving dangerous places, notwithstanding the petition of ratepayers. 
council of any city, town, village or township, by by-law passed with the assent of the electors, may direct that all future expenditure for local improvement shall be by special assessment on the property benefited. The assent of the electors is also required for the repeal of such a by-law. After the adoption of this system the council may further extend it so as to make it apply to the repairing, cleaning, watering and lighting of the streets, and also to the cutting of grass and trimming of trees.

Most of these general provisions are also found in the other Provinces of the Dominion, among which the four western Provinces follow the Ontario system quite closely. ${ }^{x}$ This similarity in policy exists also in connection with the method of ascertaining the proportion to be paid by each landowner benefited. The Baldwin Act (1849) in Ontario left to the local council the manner in which this special assessment was to be levied. The act of 1859 provided that the council might assess the property benefited either by (I) an annual ad valorem rate, including improvements; (2) a similar rate exclusive of improvements ; (3) a rate according to frontage ; (4) a rate according to benefit; or by (5) a combination of any or all of these. The Municipal Act of $1866^{2}$ restricted the localities to a special rate on the actual value of the property exclusive of improvements, and, in $1883,{ }^{3}$ the method was again changed by the substitution of a clause requiring the levying of a rate according to the frontage of the abutting property. The localities were allowed to "provide an equitable mode of assessment" in the case of corner or irregularly-shaped lots. The Municipal Act

${ }^{1}$ Manitoba Rev. Stats., 1902, c. I16; Sask. Stats., 1908, cc. 16 and 17; Alberta City Charters; B. C. Stats., 6 Edward VII, c. 32, and 1908, c. 36.

2 29-30 Victoria, c. 51 .

46 Victoria, c. 18 , ss. $612-3$. 
of Ontario still provides that the rate shall be levied according to frontage, except in certain cases in townships where the local council may declare that the rate shall be one on the lands benefited and shall be levied "according to the proportion of benefit received."'s

In most of the Provinces provision is made for the adoption of some other method of fixing the rate when that levied according to frontage appears inequitable. For example, cities in British Columbia ${ }^{2}$ may levy the cost of the improvement, or part thereof, by any of the following methods, by a combination of the frontage rate with any of these, or by a combination of any two or more : according to $X_{X}$ ) relative assessed value; ( $\lambda$ ) the number of lots; $(\mathbf{3})$ the proportionate amount of benefit; (४) the relative area of the lots benefited. The cities and towns of Alberta and Saskatchewan are permitted to make use of either the "Special Frontage Assessment" or the "Special Local Benefit Assessment."

The Province of Quebec has not as yet fully accepted the principle underlying special assessment for local improvement. Montreal, for instance, has paid for the construction of practically all of its permanent pavements out of general revenue, although it has had recourse to special assessment for certain purposes, such as the widening and extension of streets, where the expropriation of land is necessary. This tardiness in adopting a system so well adapted to the general economic conditions can be attributed to the same causes as were responsible for the absence of a general municipal system in the early part of the last century, namely, the opposition of a large portion of the population to any system which

1 Section 674 (3).

26 Edward VII, c. 32, s. 256. 
will increase the taxes on land. To this must be added the desire to keep church property free from taxation, for under the local improvement system such real estate naturally would pay its share of the expenditure.

The Legislature has just passed ' an amendment of Montreal's charter providing that the total cost of pavements of permanent materials other than wood or macadam shall be met by the owners of the realty bordering on the street or other public place where such improvement is made. This cost is to be apportioned according to frontage, and proprietors may pay their share by annual installments sufficient to pay the amount called for in forty years at five per cent interest. When any permanent pavements laid before March I4th, I9II, the date on which these provisions went into effect, are wholly or partly reconstructed, the cost of this reconstruction must be levied on the abutting owners in the manner above described. The city bears no part of the cost of permanent paving, except in the case of a public street or place having a width exceeding fifty feet, when the total cost of paving the excess is payable out of the general funds. All pavements constructed or repaired under the above provisions must be "maintained, repaired or renewed in future by the city forever."

We have seen that in Ontario the benefit to the whole community from the construction of local improvements was at first disregarded and that the cost of such works was borne entirely by the abutting owners. Gradually, however, the principle of dividing the cost between the owners immediately interested and the taxpayers of the municipality has been introduced, and we now find it firmly established in the laws of the Province. Quebec

${ }^{1}$ I George V, c. 60 (IgII), s. 25. 
has started at the other extreme. The municipalities of this Province have been meeting the cost of local improvements out of the general funds, except in cases where payments are made to the abutting owners for lands used in the carrying-out of the work. In Montreal the cost of widening and extending streets has usually been shared equally between the municipality and the owners of abutting property. To this extent has the principle of special assessment for local improvements been recognized. The change in Montreal's system described above does not conform to this principle as established in the other Provinces, since no allowance is made for the benefit conferred on the community at large by the construction of these local works. In amending the provisions for pavement construction in Montreal, the Legislature has passed from one extreme to the other.

\section{D. - STATUTE LABOR AND POLL TAXES}

Provisions for the performance of statute labor, or for the payment of poll taxes, or both, are found in all the Canadian Provinces. Ontario has a special "Act Re-

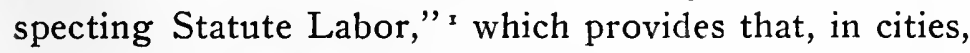
towns and villages, all male residents between the ages of 21 and 60, whose names have not been placed on the assessment roll, shall pay a yearly rate of $\$ 1.00$ instead of performing statute labor. In townships, such residents are liable to one day of statute labor on the roads of the township in which they reside, and all residents who are assessed upon the roll of the township are required to perform statute labor in proportion to the amount of their assessment, the rate being approximately

14 Edward VII, c. 25. 
one day for each $\$ 200$. Any township council may direct that this statute labor be commuted at a rate not exceeding $\$$ r.oo for each day of labor. The council of any municipality has authority to reduce or to abolish the amount of statute labor to be performed or the amount of payment in lieu of statute labor.

Provision is also made for the performance of statute labor in townships which have not been incorporated. Twenty resident landholders of any such township may hold a public meeting for the purpose of electing a road commissioner, who shall have authority to require the performance of statute labor by landholders in proportion to the number of acres held.

The Province of Manitoba ${ }^{1}$ has similar provisions regarding both the performance of statute labor in rural municipalities and the payment of a poll tax in cities, towns and villages. In the latter case, the annual payment is $\$ 2.00$. All male residents of a township or district municipality in British Columbia, whose names are not on the assessment roll, are required to perform two days statute labor. Those who are assessed must perform an amount of labor graded according to their assessment. No such labor is required, however, in municipalities which levy a road tax. ${ }^{2}$ The Provincial Government of British Columbia levies an additional tax of $\$ 3.00$, called the "Revenue Tax", 3 on all males over I 8 years of age, except militiamen and men over sixty whose incomes do not exceed $\$ 700$. This tax may be collected from employers.

${ }^{1}$ Rev. Stat. Man. (I902), c. II7, ss. 100 to II7.

$2 \$ 2.00$.

Rev. Stat. B. C. (1897), c. I67. Vide also 62 Victoria, c. 66, and I Eiward VII, c. 46. 
Before the organization of the Provinces of Alberta and Saskatchewan, the Northwest Territories had provisions for statute labor similar to those of Ontario, and, in addition, demanded a payment of $\$ 2.00$ from all males over twenty-one years of age who had been resident in a municipality for two months or more and whose names were not on the assessment roll. ${ }^{x}$ The villages of these two Provinces now levy a poll tax of $\$ 2.00$. The towns and cities ${ }^{2}$ also levy a poll tax of the same amount, which applies to all male residents of at least three months and all who reside within two miles of the municipality and are employed within it. This, however, does not apply to "householders," 3 who pay $\$ 5.00$.

Statute labor has practically disappeared from the Maritime Provinces, but in all three the poll tax still holds forth. Prince Edward Island levies a road tax of $\$ \mathrm{I} .00^{4}$ on all males between the ages of twenty-one and seventy residing in road districts, and its two cities, Charlottetown and Summerside, collect a poll tax of $\$ 2.00 .^{5}$ The rural districts of Nova Scotia are authorized to collect a poll tax of not more than thirty cents, with a like sum for a poor rate, and the cities and towns may fix this tax at a sum from $\$ 2.00$ to $\$ 5.00$ for all male residents between the ages of eighteen and sixty, who are not rated in the municipality for an amount exceeding \$200. New Brunswick gives especial prominence to the poll tax by requiring that one-sixth of the amount to be raised by a

1 Consolidated Ordinances of Northwest Territories (1898), c. 70. In the cities of Saskatchewan and some of those of Alberta the tax is $\$ 3.00$.

3 This poll tax was in addition to the one day's labor required.

O Owners or tenants paying at least $\$ 100$ annual rental.

42 Edward VII, c. 2.

3 Edward VII, c: 16 (7I); 3 Edward VII, c. I8 (86). 
municipality shall be levied by an equal rate on all male residents over twenty-one years of age, the remaining five-sixths to be levied on all assessable property.'

\section{E.-TAXATION OF MORTGAGES}

Mortgages on real estate are taxed in none of the Provinces, except New Brunswick, which still attempts to reach them under the provisions for the taxation of personal property. ${ }^{2}$ The Ontario assessment laws as far back as the act of $1853^{3}$ provide that personal property secured by mortgage shall be exempt from taxation. The interest received from mortgage investments, however, was, and still is, subject to taxation as income. British Columbia, Alberta, Saskatchewan and Nova Scotia follow the Ontario method. Manitoba has no tax on income and makes no attempt to reach mortgages. In Quebec, which has never had either the personal property tax nor the income tax, this form of investment is not taxed.

In none of the Provinces which attempt to tax the revenue derived from mortgage investments can it be said that any large proportion of such income is actually reached. Tax officials in Ontario are recommending a closer watch over the recording of mortgages, while Saskatchewan and Alberta, as we have seen, are moving toward the abolition of any direct tax on income.

${ }^{1}$ Consolidated Stats. (1903), c. I70, s. 7. By 7 Edward VII, c. 84, Fredericton levies a flat rate of $\$ 5.00$.

${ }^{2}$ Consolidated Stats. (1903), c. I70, s. 2 (3).

I6 Victoria, c. I82. 


\section{CHAPTER IX}

\section{Provincial Taxation-Corporation Taxes}

The Canadian Provinces have not yet reached a high state of development in the field of corporate taxation. Not only are corporations taxed differently by the several jurisdictions, but, within the Provinces themselves, the same principle is not applied to all classes of companies. Most of the Provinces are still trying to reach the mercantile and manufacturing corporations under the provisions for local taxation, after levying a Provincial tax on financial and transportation companies. In only two, Quebec and British Columbia, do we find a general tax levied on all incorporated companies in addition to those which have been made the objects of special taxes. Nova Scotia stands alone as having no special provisions for the taxation of corporations. Here the attempt is still made to reach this class of wealth under the general property tax provisions.

A preliminary survey will serve to give the reader an idea of the systems found in the respective Provinces:

Banks are taxed according to the amount of paid up capital, with an additional specific tax according to the number of branches, in Quebec, Ontario and New Brunswick, while Manitoba, Saskatchewan, Alberta, British Columbia and Prince Edward Island make their levy according to the number of branches in the Province.

Loan and Trust Companies are taxed according to paid up capital in Quebec, Ontario, Manitoba and Alberta; a lump sum in New Brunswick and Prince Edward Island; I07] 
and according to money invested in the Province in Saskatchewan.

Insurance Companics are taxed on the gross premiums received within their respective jurisdictions by the Provinces of Quebec, Ontario, Manitoba, Alberta and Saskatchewan. New Brunswiç levies a rate on the net premiums of fire insurance companies, a lump sum on life companies, and a combination of the two on accident and guarantee companies. Prince Edward Island collects specific amounts varying according to the kind of insurance and with domestic and forcign companies. British Columbia, under its general provisions for the taxation of all corporations other than banks, levies taxes on the income of insurance companies, which it assumes to be the same proportion of gross premiums received in the Province as is the total net income in the Dominion of the total gross premiums, but in no case less than ten per cent.

Railway's are still subject to local taxation on their property in Quebec, Nova Scotia, New Brunswick and Prince Edward Island. The Provincial tax in Quebec and Ontario is a specific rate per mile of track; Manitoba and Saskatchewan base the amount they collect from railways on the gross earnings; Alberta and British Columbia tax railway companies on their "real estate;" and the three Maritime Provinces levy no Provincial rate on railivays.

Sleeping and Parlor Car Companies are taxed in Ontario and Quebec in proportion to the amount of capital used within the Province.

Street Railways. All the five Provinces, Quebec, Ontario, Manitoba, Alberta, and New Brunswick, which levy a special tax on street railways, do so according to mileage. Steamship Companics. Only two Provinces, Quebec and 
Prince Edward Island, lay a special tax on this class of corporation. The former levies a rate on the paid up capital with an additional amount for each office in the Province, while the latter levies a flat rate.

Express Companies are taxed in Quebec on paid up capital; in Ontario and New Brunswick according to the mileage of railway operated over; in the three prairie Provinces according to the number of offices in their respective jurisdictions; and in Prince Edward Island at a specific sum for each company.

Telephone Companies are taxed in Ontario on their capitalization; Quebec combines capitalization and gross earnings; and New Brunswick takes the number of instruments in use as the index of amount payable. The three prairie Provinces own their telephone systems and, of course, levy no tax.

Gas and Electric Light Companies are taxed in Ontario on paid up capital; while Manitoba, Alberta and Prince Edward Island, the only other Provinces which single out this class of corporation, levy a lump sum.

General. British Columbia taxes upon gross revenue within the Province all corporations other than banks. These corporations are also liable for the tax on real property in the district where it is situated. Quebec taxes all corporations not otherwise provided for by a rate on the paid up capital and an additional sum for each place of business in the Province.

The Province of Quebec was the first to single out corporations as objects of special taxation. This Province, having no personal property tax, was allowing wealth in this form to escape taxation, and the Provincial authorities, in looking about for a means of increasing the revenues, naturally turned to this source, which became especially prominent after the industrial development which followed 
the institution of the "National Policy" in 1878. Quebec's first law for the taxing of corporations was passed in I882, ${ }^{1}$ two years after that of the State of New York, the passage of which, no doubt, had its influence with the Quebec legislators. This first act imposed direct taxes on banks, insurance companies, incorporated companies in general, incorporated loan companies, navigation companies, telegraph, telephone, city passenger railway and railway companies. Generally speaking, the tax was levied according to capitalization and the number of offices in the Province, except in the case of the last two classes, in connection with which mileage was made the basis of taxation.

Banks were to pay a tax of $\$ 500$ when their paid up capital was $\$ 500,000$ or less, and $\$ 1,000$ if more than $\$ 500,000$ but less than $\$ 1,000,000$; for each million or fraction of a million dollars of capital over $\$ 1,000,000$ a tax of $\$ 200$ was to be added up to a capitalization of $\$ 3,000$,ooo; the rate per million or fraction in excess of this amount became $\$$ roo. Thus a bank having a total paid up capital of $\$ 5,000,000$ was required to pay a tax of $\$ 1,600$ on its capitalization. An additional payment of $\$ 100$ for each place of business in Montreal and Quebec and \$20 in other places was also imposed.

The rates on the capitalization were amended in $1889^{2}$ by the substitution of the following:

$\$ 100$ on every $\$ 100,000$ of paid up capital up to $\$ \mathrm{I},-$ 000,000.

$\$ 50$ on every $\$ 100,000$ of paid up capital over $\$ \mathrm{I}, 000$,ooo, but less than $\$ 3,000,000$.

$\$ 25$ on every $\$ 100,000$ of paid up capital over $\$ 3,000$,ooo, but less than $\$ 6,000,000$.

145 Victoria, c. 22.

51-2 Victoria, c. Ir.

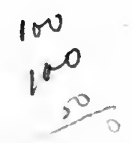


$\$ 15$ on every $\$ 100,000$ of paid up capital over $\$ 6,000$,ooo.

Under these rates a bank with a paid up capital of \$5,ooo,ooo was required to pay $\$ 2,500$ as a tax on its capitalization. Special rates were levied in $1896^{1}$ on banks organized outside of the Province. Such banks having a capital of $\$ 1,000,000$ or less pay a tax of one-tenth of one per cent on the amount of capital; when the capital exceeds $\$ 1,000,000$ but falls below $\$ 2,000,000$, a lump sum of $\$ \mathrm{I}, \mathrm{OOO}$ is paid; and when in excess of $\$ 2,000,000$, a total payment of $\$ \mathrm{I}, 500$ is demanded. This discrimination in favor of foreign banks was made in order to allow for the taxes paid in the Province in which they originate.

The act of $1906^{2}$ increased the rate on banks with large capitalization by removing the last two clauses of the schedule, leaving it at $\$$ IOO for every $\$ 100,000$ up to $\$ \mathrm{I}$,000,000 , and $\$ 50$ for every $\$ 100,000$ over $\$ 1,000,000$. The specific rate per office was increased to $\$ 200$ for the head office in Montreal and Quebec, $\$_{15} 0$ for each other office in these cities, and $\$ 30$ for each office in other places in the Province. These increases are due to the great development of the banking business throughout the Dominion and the feeling prevalent that this class of business was not bearing its fair share of taxation. That the rate is not too high is evident to all who are familiar with the increase in the number of branches in all the cities of the Province during the last few years.

Under the first act imposing taxes on corporations, life insurance companies were required to pay a flat rate of $\$ 500$, and companies engaged in any other form of insurance $\$ 400$. Those carrying on more than one kind of in-

159 Victoria, c. 15.

26 Edward VII, c. Io. 
surance were required to pay $\$ 50$ additional for each. There was also imposed a tax of \$Ioo for each office in Montreal and Quebec and $\$ 5$ for each office in other places in the Province. These rates were amended in $1889,{ }^{1}$ by making the $\$ 500$ rate general for all companies doing one class of business and by levying a tax of one-tenth of one per cent on the paid up capital of plate-glass insurance companies. The act of $1896^{2}$ added live-stock insurance companies to the latter class, and imposed on marine insurance companies a tax of $\$ 200$, with an additional $\$ 50$ for each office in the Province.

In $1900,{ }^{3}$ the basis of the tax was changed by the introduction of one levied according to the gross premiums received or become due. Life insurance companies were taxed one per cent and others two-thirds of one per cent on the amount of such premiums. An exception to the general rate is made in the case of mutual fire insurance companies which pay the tax only on the gross premiums received in cash. The minimum tax, under this act, was to be $\$ 250$. The act of $1906^{4}$ increased the rates to one and three-fourths per cent and one per cent and the minimum tax to $\$ 400$ for life insurance companies and $\$ 250$ for others. There was also added a retaliatory clause regarding discrimination by other Provinces against companies incorporated in Quebec.

Loan companies were at first taxed $\$ 400$, and $\$ 50$ for each million, or fraction of a million dollars, in excess of $\$ 1,000,000$, with an additional \$roo for each office in Montreal and Quebec and \$20 in other places. All companies without fixed capital are required to pay $\$$ Ioo as a

5I-2 Victoria, c. II.

${ }^{2} 59$ Victoria, c. 15 .

36 Victoria, c. I3.

- 6 Edward VII, c. 10. 
tax. The amending act of 1889 introduced a schedule ${ }^{1}$ for loan companies having a fixed capital less than $\$ 500$,ooo, thus removing the pressure on the smaller companies. It also provided that the tax for each office shall be $\$$ roo in Montreal and Quebec and $\$ 50$ in other places when the fixed capital of the company exceeds $\$ 100,000$, and $\$ 50$ and $\$ 25$, respectively, when it is less than $\$ 100,000$ or when there is no fixed capital.

An act of $1905^{2}$ introduced a special tax on trust companies. These pay one-fifth of one per cent on their capitalization up to $\$ 1,000,000$ and $\$ 25$ for each $\$ 100,000$ over this amount, with an additional tax of $\$ 50$ for each place of business in Montreal and Quebec and $\$ 20$ in other places. The Lieutenant-Governor is authorized to reduce the amount of this tax when the company operates outside of the Province, but the total tax must not fall below one-fifth of one per cent on the total capital employed in the Province.

Under the act of $\mathrm{r} 882$, incorporated navigation companies were required to pay a tax of $\$ 100$ when the paid up capital was $\$ 100,000$ or less, $\$ 200$ when the amount of this capital was between $\$ 100,000$ and $\$ 500,000$, with an additional $\$ 100$ for each $\$ 500,000$ or fraction thereof over this amount. The maximum tax was to be $\$ 1,000$. In 1889 , these rates were amended by the substitution of the following which are still in force. All navigation companies are required to pay one-tenth of one per cent on their capital up to $\$ 500,000$ and $\$ 50$ for each $\$ 100,000$ exceeding this amount. There is also a tax of $\$ 50$ and $\$ 20$ for each office in Montreal and Quebec and in other places, respectively.

$1 \$ 100,000$ or less-one-tenth of one per cent; $\$ 100,000$ to $\$ 200,000-$ $\$ 150 ; \$ 200,000$ to $\$ 300,000-\$ 200 ; \$ 300,000$ to $\$ 400,000-\$ 250 ; \$ 400,000$ to $\$ 500,000-\$ 300$.

5 Edward VII, c. 14 
Telegraph companies were at first required to pay a tax of $\$ \mathrm{I}, 000$, with an additional $\$ 5$ for each office in the Province. The act of 1889 introduced a rate of one-tenth of one per cent on the capitalization of all companies having a capital of $\$ 50,000$ or less, and $\$ 2,000$ for all having a capitalization over this amount. The present tax of $\$ I, 000$ for all companies operating telegraph lines for public use was re-introduced in $1905 .{ }^{1}$

The act of 1882 imposed on telephone companies a tax of $\$ 500$, and $\$ 100$ and $\$ 50$ for the principal station in Montreal and Quebec and in other places, respectively. In I889, the tax was made proportionate, one-tenth of one per cent on the capitalization, for all companies having a capital less than $\$ 50,000$, and a tax of $\$ 1,500$ was required from all companies having a capital in excess of $\$ 50,000$. The act of $1895^{2}$ introduced a schedule of rates ${ }^{8}$ for all companies with a capital exceeding $\$ 50,000$, so as to make the amount of tax payable more nearly proportionate to the capitalization. These rates are still in force, except that, in $1906,{ }^{4}$ a tax of one-half of one per cent on the gross earnings of all companies having a capital exceeding $\$ 300,000$ was introduced, the total amount of tax not to be less than $\$ 2,000$ nor more than $\$ 3,000$.

An act passed in $1903^{5}$ imposed on all express companies foreign to the Province a tax of one-tenth of one per cent on the amount of capital up to $\$ 1,000,000$ and $\$ 25$ for each $\$ 100,000$ over this amount, with an additional tax of $\$ 50$

15 Edward VII, c. 14.

259 Victoria, c. 15 .

s $\$ 50,000$ to $\$ 100,000-\$ 250 ; \$ 100,000$ to $\$ 200,000-\$ 500 ; \$ 200,000$ to $\$ 300,000-\$ 1,000$; all over $\$ 300,000-\$ 1,500$.

46 Edward VII, c. Io.

s 3 Edward VII, c. 19. 
for each office in Montreal and Quebec and \$20 in other places in the Province. In 1906, the rate on the capital was changed to a tax of one-half of one per cent on the gross earnings, the total amount to be paid not to fall below \$500. There was also introduced a tax of one-fifth of one per cent on the capital of express companies foreign to the Dominion.

Railways, whether horse, electric or steam, have always been taxed according to mileage. Under the act of 1882 , city passenger railways were required to pay a tax of $\$ 50$ for each mile operated, and the act of I889 made the rate $\$$ Ioo per mile for double-track systems. These rates are still in force.

In 1882 , certain railways, specified in the act, were taxed at the rate of $\$ 20$ per mile while others paid $\$ 5$ per mile. The first amendment came in 1889 , when the former rate was reduced to \$Io. The act of 1895 added to the list of railways to pay the higher rate all those which had received Government aid. A new schedule of rates was drawn up in $1907,{ }^{1}$ when the following were imposed on all railways, steam or electric: On the main line, $\$ 30$ per mile of single track and \$I 5 per mile for each additional track; on branch lines, \$20 per mile single and \$Io per mile for each additional track. The assessment and taxation locally of real estate belonging to railways, including the roadway, is responsible for these low rates. The same act brought under taxation sleeping and parlor car companies by imposing on them a tax of one-third of one per cent on the amount of capital used in the Province and an additional tax of $\$ 50$ and $\$ 20$ for each office in Montreal and Quebec and in other places, respectively.

The general tax on incorporated companies was placed,

17 Edward VII, c. 13. 
in 1882 , at $\$ 100$, with an additional payment of $\$ 50$ for each quarter million dollars or fraction thereof in excess of the first $\$ 250,000$ of paid up capital. The tax for each place of business was $\$ 50$ or $\$ 20$ according to location. The act of 1889 amended these provisions by introducing a proportionate rate of one-tenth of one per cent on the capital up to $\$ 1,000,000$, and $\$ 25$ for each $\$ 100,000$ or fraction over this amount. In $1895,{ }^{1}$ the Lieutenant-Governor was authorized to reduce the rate when the company operates outside of the Province, but not lower than onetenth of one per cent of the capital employed within the Province. The rate was changed in $1906^{2}$ to one-eighth of one per cent up to $\$ 1,000,000$, and $\$ 50$ for every $\$ 100$,ooo or fraction in excess.

The chief point to be noted in the development of the Quebec method of taxing corporations is the tendency toward proportionate rates. In the act of 1882 , there were no percentage rates. All were lump sum taxes, graduated, in some cases, according to the amount of capital. The act of 1889 introduced percentage rates in the case of plateglass insurance companies, navigation, telegraph and telephone companies and incorporated companies in general. In 1895, this was extended to extra-Provincial banks with a capital less than $\$ 1,000,000$ and to loan companies, and, in 1906 , to insurance companies, extra-Provincial express companies, parlor car companies, trust companies and corporations with their chief place of business outside of Canada. $^{3}$ The percentage tax of 1906 on the insurance and express companies and corporations foreign to Canada is on gross receipts rather than on capitalization, thus indi-

${ }^{1} 59$ Victoria, c. I5.

26 Edward VII, c. Io.

3 One-half of one per cent on gross earnings; also $\$ 50$ and $\$ 20$ for each office. 
cating a further step in the direction of a more scientific system.

From the viewpoint of fiscal returns, these special taxes on corporations have been quite successful. The revenue from this source in 1895 was $\$ 160,756$ or six and seventenths per cent of the total Provincial revenue from sources other than the Dominion grant and Crown lands. In I905, it was $\$ 303,882$ or twelve and one-tenth per cent of revenue, and in I9II, \$7I2, I I8 or eighteen and three-tenths per cent of revenue after making deductions as for 1895 . This increase is due to higher rates and to the broadening of the scope of the act taxing corporations as well as to the growth in the number and magnitude of the corporations themselves.

Before the year I899, the taxing of corporations in the Province of Ontario was left entirely to the various local authorities, who were trying to reach corporate wealth under the general property tax by assessing the shares against the holders. Some part, at least, of the personal property invested in corporate securities was reached locally, and, for this reason, we find no Provincial tax until I899, when the agitation against the personal property tax was at its height. Even then the "Supplementary Revenue Act" 1 did not attempt to reach mercantile and manufacturing corporations, but merely added to the tax already levied on corporate shares by the municipalities a Provincial tax on corporations of a semi-public character. The act expressly states that the companies which are required to pay taxes to the Province "shall continue to be assessable and taxable for municipal purposes as heretofore."

Banks are taxed on their paid up capital at the rate of

162 Victoria, c. 8. 
one-tenth of one per cent up to $\$ 2,000,000$, and $\$ 25$ for every $\$ 100,000$ or fraction in excess of this amount and not exceeding $\$ 6,000,000$. There is an additional tax of $\$$ Ioo for the head office in Ontario and $\$ 25$ for each additional branch or agency. Banks, having their head office out of the Province and not more than five branches within Ontario, may have the amount of tax payable reduced by the Lieutenant-Governor, but not below one-tenth of one per cent on one-half of the total paid up capital. ${ }^{1}$

Loan companies with fixed or permanent capital must pay a tax of $\$ 65$ when their paid up capital is $\$ 100,000$ or less, and of 65 cents on every $\$ 1,000$ exceeding this amount. In the case of a company with terminating capital only, the rate is $6_{5}$ cents per $\$ 1,000$ after the first $\$ 100,000$ of capital. The Lieutenant-Governor may direct that the tax shall be calculated on the amount of capital used in the Province, when a loan company is incorporated out of Ontario.

Trust companies are taxed $\$ 250$ on their paid up capital up to $\$ 100,000$, and $\$ 65$ for every $\$ 100,000$ or fraction in excess of this amount. Where the gross profits are $\$ 25,000$ or more per annum, the company must pay a further sum of $\$ 500$. The income from paid up capital which may be invested is not to be reckoned as gross profits.

Life insurance companies pay one per cent on the gross premiums received in the Province, other insurance companies two-thirds of one per cent. Mutual fire insurance companies are taxed only on the business done on the cash plan. Where an extra-Provincial life insurance company has an annual income of less than $\$ 20,000$ from premiums in Ontario, and lends money on the security of real estate in the Province, a tax of one-fourth of one per cent on the gross income from such investments and from loans on 
policies must be paid in addition to the one per cent on gross premiums. As in Quebec, the Lieutenant-Governor is empowered to levy a retaliatory surtax on any company incorporated in another Province or other jurisdiction in which Ontario companies are discriminated against by the imposition of a higher tax than that demanded from home companies.

Telegraph companies pay a tax of one-tenth of one per cent on the capital invested in Ontario, while telephone companies must pay one-eighth of one per cent of the total paid up capital. Privately-owned gas and electric light companies in any city in the Province pay a tax of onetenth of one per cent on their capital.

The Provincial Government of Ontario collected no taxes from railway companies before 1899. They were taxed by the municipalities and on their real estate only. Each locality assessed, according to the average value of the neighboring lands, that part of the roadbed lying in its jurisdiction, and also all other real estate of the company in the municipality. The act of I899 levied a tax of $\$ 5$ per mile on the main line, which rate, it was expressly stated, was to be in addition to the municipal taxes then in force. The Assessment Act of $1904,{ }^{1}$ makes liable to municipal taxation the rails, ties, poles and other superstructures of railways when such structures are situated upon a public highway. The rate of the Provincial mileage tax was increased in this year ${ }^{2}$ to $\$ 30$ per mile for one track and $\$$ Io per mile for each additional track in the organized districts of the Province and $\$ 20$ and $\$ 5$ in unorganized territory. Independent companies having a line of track not exceeding I50 miles were required to pay $\$ 15$ per mile single track and $\$ 5$ per mile for each additional track.

14 Edward VII, c. 23 .

${ }^{2} 4$ Edward VII, c. 5 . 
As a result of the problems disclosed in the hearings before the Assessment Commission of I900, a Commission on Railway Taxation was appointed in 1904 to inquire into and report upon the various phases of railway tay legislation in the United States, Great Britain and Canada. The report of this Commission appeared in 1905 , and contains much valuable information on both municipal and Provincial taxation. The recommendations are, in brief, as follows:

(a) A gross earnings tax of about three per cent on railroad and similar corporations, such as telegraph, express and sleeping car companies.

(b) The restriction of the municipal authorities to the taxation of the real property of railways exclusive of the roadbed, the amounts paid to the municipalities on real estate to be deducted from the total tax on gross earnings levied by the Province.

(c) The establishment of a Provincial Board of Taxation to administer the corporation tax laws and to prevent double taxation.

The Legislature followed the second of these recommendations in $1906,{ }^{1}$ when the roadbed was removed from the list of railway property locally taxable. As compensation to the municipalities for the loss resulting from this limitation in their taxing powers, it was also provided in this year ${ }^{2}$ that one-half the Provincial revenue from railway taxation, less $\$ 30,000$, shall be distributed annually among the municipalities of the Province, according to population. Against the amounts so to be paid to any municipality, however, there is charged the sum of ten cents per day for each patient, belonging to that munici-

16 Edward VII, c. 36.

26 Edward VII, c. 9. 
pality, maintained in any lunatic or other asylum of Ontario, on account of whose maintenance the Province is not in receipt of $\$ 1.50$ per week.

In $1908,{ }^{1}$ the Legislature increased the rates on railways, and again in $19 \mathrm{Ir},{ }^{2}$ for couble-track systems. Companies operating in any organized municipality now pay $\$ 60$ per mile for one track and $\$ 40$ per mile for each additional track. In unorganized districts the rate is $\$ 40$ per mile single and $\$ 20$ for each additional track. Railways not exceeding I 50 miles in length still pay the same rates, $\$_{15}$ and $\$ 5$, and companies whose lines do not exceed 30 miles now pay $\$ 10$ and $\$ 5$ on the first and other tracks, respectively. Sleeping and parlor car companies are taxed at the rate of one-third of one per cent on the capital invested in rolling stock used in the Province.

Street railway companies are taxed in proportion to the number of miles of line within the limits of any city. The rates are $\$ 20, \$ 35, \$ 45$ and $\$ 60$ per mile, according to the length of the system, the minimum being for companies whose total mileage does not exceed 20 miles and the maximum for those having a mileage in excess of 50 miles. One mile of double track is counted as two miles single, but the measurement is not to include switches, spurs and sidings not in general use for passenger traffic.

Under the act of 1899 , express companies were required to pay a tax of $\$ 800$ when they operated over 400 miles of railway or less and $\$ 125$ for each additional 400 miles or fraction. These rates were increased in I9I I ${ }^{3}$ to $\$ 500$ for each roo miles or fraction, with a resulting increase in revenue from $\$ 6,500$ in 1910 to $\$ 4 \mathrm{I}, 000$ in I9I $\mathrm{I}$.

18 Edward VII, c. 14.

${ }^{2}$ I George V, c. 5, s. I.

s I George V, c. 5, s. I. 
The amending act of $19 \mathrm{II},{ }^{1}$ also introduced a license tax on associations conducting race-meetings and a tax on the transfer of corporate securities. The amounts payable under the former are $\$ 200$ or $\$ 10$ for each day of a meet, according to its character. ${ }^{2}$ The second is a rate of two cents for every $\$ 100$, or fraction thereof, of the par value upon the transfer of shares or debenture stock effected in the Province. This tax is similar to that levied in Quebec, where the transfer of bonds is also included. ${ }^{3}$

The revenue from the taxes imposed under the Supplementary Revenue Act was $\$ 217,059$ in 1899, or thirteen and five-tenths per cent of the total receipts of Ontario, less the amounts received from Crown lands and the Dominion Government. In I910, the yield was $\$ 75^{2}, 338$, or twenty-two and one-tenth per cent of all revenue, less that received from the above two sources and from the $T$. \& N. O. Railway, which is owned by the Ontario Government. This was increased in I9I I to $\$ 854,659$, or twentyone and nine-tenths per cent of all revenue after making deductions as for 1910. The greatest increase took place in 1906 , when the returns from this source rose by nearly $\$ 200,000$, due mostly to the change in the taxation of railways. This class of corporations now contributes more than one-half the revenue derived under the act. ${ }^{4}$

In I900, the Province of Manitoba followed Ontario with a Corporations Taxation Act $^{5}$ and a Railway Taxation Act. ${ }^{6}$ The former provided for the payment of taxes by banks, insurance companies, loan and trust companies,

1 I George V, c. 5 .

2 Section 4.

${ }^{3}$ Vide Que. Stats., 5 Edward VII, c. I5 and 6 Edward VII, c. I2.

4 Vide Public Accounts, I9Io, pp. a39-a45 and I9II, pp. a42-a48.

${ }^{5}$ 63-4 Victoria, c. 55 .

6 63-4 Victoria, c. 57. 
street railway, telegraph, telephone, gas, electric light and express companies, while the latter applies to steam railways only. These acts removed these corporations from the tax jurisdiction of the municipalities, except as regards real estate.

Banks are required to pay $\$ 800$ for the head office, and $\$ 200$ for each branch when there are not more than four and \$100 each when there are more than this number, only one such tax to be paid in any municipality. Private banks pay $\$ 200$ or $\$ 100$, according to whether the population of the place where they are situated exceeds or falls below 500 , and $\$ 25$ for each branch in the Province.

Insurance companies pay a tax of one per cent on their gross premiums. Where the annual receipts of a company from premiums are less than $\$ 20,000$ and the company has $\$ 100,000$ invested in the Province, three-fourths of one per cent is levied on the receipts and one-half of one per cent on the income received from investments in the Province.

Loan and trust companies are taxed on the amount of capital after being allowed an exemption equal to the amount of taxable land held by them. The latter class pay an additional amount when the gross annual profits exceed $\$ 25$,ooo.

Street railway companies having a mileage of twenty miles or less pay $\$ 500$, and those whose mileage exceeds twenty add \$1 o for each mile in excess.

Telegraph companies were at first required to pay $\$ 1.00$ per mile of line operated and telephone companies 50 cents per instrument in cities having a population over 10,000 and 25 cents in other municipalities. An amending act of I $906,{ }^{1}$ however, changed these rates by the substitution of

${ }^{1}$ 5-6 Edward VII, c. 87. 
a tax on gross receipts, the rate to be fixed by the Lieutenant-Governor, but not to exceed two per cent. This tax, as applied to telephone companies, has been inoperative. except in one or two minor cases, since the acquisition of the telephone system of Manitoba by the Provincial Government.

Privately-owned gas companies in cities pay $\$ 500$, and electric light companies an equal amount in cities with a population of 10,000 or more, $\$ 100$ when in cities with a population under 10,000 , and $\$ 25$ in other municipalities. ${ }^{1}$ Express companies pay $\$ 250, \$ 500$ or $\$ 1,000$, according to whether they have less than 50,50 to 100 , or more than Ioo offices in the Province.

Since I906, every corporation or joint stock company which receives money on deposit at interest must pay annually, in addition to other taxes, the sum of $\$ 200$ when such deposits do not exceed $\$ 100,000$, and one-tenth of one per cent on each additional $\$ 100,000$ or part thereof up to $\$ \mathrm{I}, 000,000$.

Manitoba's system of railway taxation is quite simple in form. Provision is made for a tax on gross earnings, the rate to be determined by the Lieutenant-Governor, but not to exceed three per cent. Railway companies are exempt from all other taxes, except those imposed on the land subsidy from the Dominion, or on land held for sale, ${ }^{2}$ and the frontage tax for local improvements. No basis for ascertaining the proportion of the total earnings of the railroad taxable in the Province is provided in the act, but

${ }^{1} 9$ Edward VII, c. 72 introduced a new schedulc for electric light companies. The rates range from $\$ 25$ in towns with populations under 3,000 to $\$ 500$ in cities of 75,000 to 125,000 and $\$ 100$ for each 50,000 in excess.

2 By 9 Edward VII, c. 73, the property of a railway company not in actual use in the operation of the railway is taxable locally. 
each company is required to deliver to the Provincial Treasurer "a statement showing fully and completely the gross earnings of the line or lines . . . or parts of lines of railways in the Province owned or operated during the year." The Treasurer is authorized to examine under oath the offcers and employees of the company making such statement and is given full power to require the production of documents and to enforce the attendance of witnesses. Should he be of the opinion that the amount of gross earnings given in the statement of the company is too low, he may appoint, with the approval of the Lieutenant-Governor, a committee to determine the true gross earnings. The report of this committee is final.

The rapid railway development in western Canada during the last few years has increased Manitoba's revenue from this source from about $\$ 65,000$ in 1903 to $\$ 139,374$ in 1910. In the latter year $\$ 228$, or I, or eighteen and onetenth per cent of total revenue (less amounts received from the Dominion, from public lands and from the telephone system), was furnished by the Railway and the Corporations Taxation Acts.

In the acts providing for the taxation of certain corporations passed by the Legislatures of Saskatchewan ${ }^{1}$ and Alberta $^{2}$ in 1907 , the influence of Manitoba's legislation can be seen. The former Province taxes banks $\$ 400$ for the head office, $\$ 100$ for each branch up to and including four, $\$ 50$ for each branch over four and up to eight, inclusive, and $\$ 25$ for each branch over eight. Alberta has the same rate on the head office of banks, but levies $\$ 200$ for each branch up to and including four, and \$IOo for each branch over four. In both Provinces, private banks pay $\$ 200$ for the head office when situated in a city or

1 I907, c. 22.

21907 , c. 19. 
town and $\$ 100$ when in a village, with $\$ 25$ additional for each branch in the Province.

Life insurance companies in Saskatchewan pay one per cent, other kinds two-thirds of one per cent, on the gross premiums received in the Province. In Alberta all insurance companies are taxed one per cent on gross premiums. In both Provinces, it is provided that a foreign insurance company, which lends money on security and which has $\$ 100,000$ invested in the Province, must pay a tax of threefourths of one per cent on the gross premiums received in the Province and one-half of one per cent on its income from investments in the Province. Saskatchewan makes this provision apply only to such companies the gross premiums of which are less than $\$ 20,000$, as in the case of Manitoba.

Loan and trust companies in Saskatchewan pay 40 cents for every $\$ \mathrm{I}, 000$ used in investments. Alberta levies on these companies specific sums roughly proportionate to the amount of paid up capital, its provisions for these taxes being practically the same in all features as those of Manitoba. ${ }^{1}$

The Saskatchewan act provides that telegraph and telephone companies shall pay one per cent on their gross receipts, while that of Alberta has the same rates as were levied under Manitoba's first act, namely, \$1.00 per mile of line for the former, and 50 cents or 25 cents per instrument on the latter. Neither Province, however, collects taxes from the telephone systems, since they have been acquired and are operated by the Provincial Governments and the municipalities.

Saskatchewan taxes express companies $\$ 100$ and $\$ 3.00$ additional for each branch in excess of 25 . Alberta has 
Manitoba's rate of $\$ 250, \$ 500$ or $\$ 1,000$, according to the number of offices. This Province also levies the same rates as Manitoba on gas and electric light companies, ${ }^{1}$ and on street railways, with the exception that Alberta's initial rate when the mileage is twenty or less is $\$ 200$ instead of $\$ 500 .^{2}$

Alberta and Saskatchewan are in a unique position as regards the taxation of railways. The ordinances of the Northwest Territories, which were in force before the formation of these Provinces, provided that all railway property, including the right of way, was taxable by the localities. But these provisions were rendered practically inoperative by a clause in the charter granted the Canadian Pacific Railway by the Dominion Government in I88I, which exempted the property of the company from all taxation, whether Dominion, Provincial or local. When the two Provinces were organized in 1905 , it was enacted that the property and capital stock of the Canadian Pacific should continue to be free from taxation. This deprives the two Provinces of one of the largest sources of revenue, and unless it will be possible to devise a method of conforming to the letter of the law and at the same time compelling the company to contribute to the support of the Provinces, it is not likely that this railway will be taxed.

The Legislature of Saskatchewan provided in its Railway Taxation Act of $1908^{3}$ that all railway companies operating lines or parts of lines in the Province must pay such portion of the gross earnings as shall be determined by the Lieutenant-Governor-in-Council, the rate not to exceed three per cent for railways which have been in opera-

1 Manitoba's rate was amended in I909. Vide note p. I24.

$2 \$ 200$ was the tax first imposed in Manitoba; increased to $\$ 500$.

I 1908 , c. 32 . 
tion for seven years or more, and one and one-half per cent when in operation more than five years but less than seven. No railway which has been in operation for less than five years is to be taxed. Each railway company in the Province is required to furnish to the Provincial Treasurer a statement of its finances, the penalty for failure to do so being a fine of $\$ 25$ a day during which default is made and liability to double taxation. The LieutenantGovernor may appoint a committee to examine into the truth of this statement, and. if the amount of gross revenue stated therein is found to be too low, the company must pay not only the costs of the examination but also an increase of fifty per cent in the amount of the tax (except when the original statement has been rendered in good faith). Railway companies are exempt from all other taxation, with the exception of a frontage tax for local improvements in the cities of the Province.

The Government of Saskatchewan has endeavored to tax the Canadian Pacific Railway under the above provisions on the grounds that the Dominion statutes provide for an exemption of real and personal property only. No legal decision has yet been rendered on this point. The company, however, without admitting its liability, has agreed to pay the Government a sum corresponding to the amount which might be imposed on it under the act. For the four years 1907 to 1910 , inclusive, there has been paid under this agreement the sum of $\$ 179,000$ out of a total of $\$ 208,664$ collected, the remaining $\$ 29,664$ having been paid by the Canadian Northern Railway Company.

Alberta ${ }^{1}$ taxes railways on their property at the rate of one per cent on a valuation of $\$ 20,000$ per mile. An act of $1908 .^{2}$ exempted all railways which have been in opera-

1906 , c. 30.

2 I908, c. 20. 
tion for less than seven years, and, in $1909,{ }^{1} \$ 30$ per mile within the Province was declared to be the maximum amount of taxes for railways which have been aided by a Provincial guarantee of their securities, such maximum rate to apply during the currency of the guarantee but not for a period exceeding thirty years in all. In 1909, Alberta collected $\$ 68,490$ from this source. This amount includes taxes levied on branches of the Canadian Pacific which are not exempt from taxation.

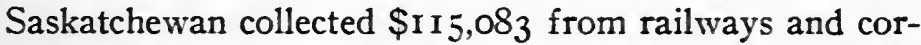
porations in I9IO-I I out of a total revenue of $\$ 5,576,626$, which includes the Dominion subsidy of $\$ 1,276,850$, proceeds from loans to the amount of $\$ 2,920,000$ and $\$ 214$,245 revenue from the telephone department. Alberta's revenue from these sources in 1909 was $\$ 109,357$ out of a total of $\$ 2,605,601$ of which amount the Dominion furnished $\$ 1,340,195$.

The Legislature of the Province of British Columbia, in providing for the taxation of all personal property and income in the Province and of all realty lying outside the municipalities, has also made provision for the taxation of certain classes of corporations. The Assessment Act of I90I, ${ }^{2}$ declares that banks and other corporations are to be taxed on the income derived from business transacted in the Province, and that, in case such income is derived from taxable personal property, the corporation is to pay only that tax which is greater in amount. The Minister of Finance was to depend on the statements of the corporations as to the amounts of personal property and of income earned within the Province, except in the case of life insurance companies, where the net income was ascertained by a comparison with the net income for the whole Dominion,

1 Ig09, c. 5, s. 10.

2 I Edward VII, c 56. 
it being assumed that the same ratio of net to gross income existed in the Province and in the whole Dominion.

The Assessment Act of $1903,{ }^{1}$ makes provision for the taxation of banks on their net income within the Province at the following rates:

(a) When the net income is less than $\$ 10,000-$ two and one-half per cent.

(b) When the net income is from $\$ 10,000$ to $\$ 20,000$ -three per cent.

(c) When the net income is over $\$ 20,000$ - three and one-half per cent.

These were in addition to the Provincial tax on real property and non-revenue-bearing personal property levied in the assessment districts where such were situated.

Certain specified corporations ${ }^{2}$ were also singled out for a special tax of one per cent on the gross revenue derived within the Province, such corporations to be at the same time liable to the $\operatorname{tax}$ on real property. In $1905,{ }^{3}$ these provisions were extended so as to include other corporations and provision was made for the furnishing of statements by the companies with penalties for default and for false statements.

The Assessment Act ${ }^{4}$ now in force makes the income of banks taxable at the same rates as that of private individuals. Income up to and including $\$ 2,000$ pays a rate of one and one-half per cent, this rate increasing with the amount of income up to four per cent on incomes over

3-4 Edward VII, c. 53.

2 Telegraph, telephone and express companies; electric light companies; electric power and street railway companies.

s 5 Edward VII, c. 50; certain insurance companies, guarantee, loan and trust companies, and gas and water works companies were added.

- 6 Edward VII, c. I. 
$\$ 7,000$. In $1907,{ }^{1}$ the minimum tax on banks was fixed at $\$ 1,000 .^{2}$ This act also made special provisions for the taxation of canneries. These are required to pay, in addition to the tax on real and personal property and income, a tax of two cents on every case of salmon and one per cent on the gross returns from all salmon other than canned. The assessment value of the personal property of canneries is also fixed by this act according to the number of "lines" in the establishment.

British Columbia taxes railways under the general Assessment Act but has a special act $^{3}$ providing for the assessment of all railway property, including the right of way, personal property and income, as real estate at a valuation of $\$ 10,000$ per mile and $\$ 3,000$ per mile for switches, spurs and sidings. The tax rate under the Assessment Act of 1910 is one-half of one per cent. ${ }^{4}$ The provisions for railway assessment do not apply to property situated within the limits of any municipality in the Province nor to any electric railway within a municipality. Log, coal and ore railways are expressly exempted.

New Brunswick also levies special taxes on certain corporations. $^{5}$ Fire insurance companies are required to pay a tax of one per cent on their "net premiums" "and an additional $\$ 100,{ }^{7}$ when the chief place of business is not in

17 Edward VII, c. 43.

'In Igio (Io Edward VII, c. 47) the tax on banks was changed to a specific tax of $\$ 1,000$ where there is only one office in the Province, and $\$ 125$ for each additional office.

37 Edward VII, c. 42. 4 Io Edward VII, c. 47.

- Consol. Stats., 1903, c. 18.

- Gross premiums less amount paid for re-insurance and cancellation of policies.

? I George V, c. 23 doubles this tax for companies foreign to the Province and not having Dominion license. 
the Province. Life insurance companies having their principal organization and office within the Province pay \$IO0, others \$250. Accident and guarantee companies pay $\$ 25$ and one-half of one per cent on the premiums received in the Province. Trust, loan and building companies pay a tax fixed by the Lieutenant-Governor-in-Council, but not to exceed $\$ 250$. $^{1}$

The amount payable by banks varies not only with the capitalization and the number of branches but also with the location of the head office. Domestic banks, having their head office in St. John and with a capital of $\$ 500,000$ or more, pay $\$ 1,000$ and $\$ 100$ for each office in the Province. This is reduced to $\$ 200$ and $\$ 100$ per branch when the head office is not in St. John and the capital is less than $\$ 200,000$. Banks, which are foreign to the Province and have an office in St. John, pay $\$ 1,000$ or $\$ 750$, with an additional $\$ 100$ per office, according to whether their capital is $\$ I, 000,000$ or $\$ 500,000$. Those without a St. John office and with a capital between $\$ 500,000$ and $\$ 1,000,000$ pay $\$ 500$ and $\$ 100$ per branch.

Express companies pay $\$ 50, \$ 125$ or $\$ 500$ according to mileage of railway operated over. Telephone companies are taxed at the rate of twenty-five cents for each instrument rented, and telegraph companies pay $\$ 500$, except for lines of less than Ioo miles, when the tax is $\$$ Ioo. Street railway companies may be taxed from $\$ 50$ to $\$ 100$ per mile of line at the discretion of the Lieutenant-Governorin-Council. All extra-Provincial companies not taxed under the above provisions are required to have a "license," the fee for which is $\$ 50$ or $\$ 100$ according to whether the capitalization is below or above $\$ 100,000$. Railways are taxed by the municipalities and on their real

1 Trust and loan companies paid \$50 in I9Io. 
estate only, the rolling stock and personal property being exempt.

New Brunswick received $\$ 36,949$ in I9Io from taxes on incorporated companies out of a total revenue of $\$ 1,324,-$ 440. The returns from the extra-Provincial corporations' license fees were $\$ 5,853$. The two sources together furnished twenty and five-tenths per cent of the revenue after deducting $\$$ I, II 5,852 for grants from the Dominion and for territorial revenue.

Prince Edward Island levied its first act for the taxing of certain " companies and associations" as early as 1894, , when flat rates were imposed on insurance companies, banks, telegraph companies and trust, loan and building associations. Other classes of corporations were added in I899 and $1900,{ }^{2}$ but the principle of levying flat rates for each kind of company has not been departed from.

The detailed account of corporation taxes in Canada given in the above pages show that this form of taxation is still in the early stages of development. Few attempts are made to arrive at any basis of taxation that will distribute the burden equally among the various corporations of any one class or among the different classes of corporations. The primary purpose, generally speaking, is to raise a revenue, and all principles of equality are relegated to the background to make room for bases of taxation which scarcely even approximate justice. In a few instances, we find a tendency toward the adoption of gross or net income as a measure of the amount of tax to be demanded. This is especially true in the western Provinces, among which British Columbia, with its one per cent tax on gross returns, stands out most prominently. Manitoba and Sas-

${ }^{1} 57$ Victoria, c. 3 .

. 62 Victoria, c. 18 ; 63 Victoria, c. 16. 
katchewan, by the imposition of taxes on the gross earnings of railway and telegraph companies, have also made a move toward the establishment of a more equitable system.

Insurance companies are taxed on premiums in practically all of the Provinces. British Columbia taxes net premiums of all insurance companies, the amount of which it arrives at by assuming that the ratio of operating expenses to gross revenue is the same for the Province as for. the whole Dominion. The taxation of insurance companies is further evidence of the regrettable tendency on the part of legislators to tax objects which will yield a revenue with the least exertion on the part of the officials. There is no more reason for the taxing of insurance companies on premiums than for the taxation of banks on deposits. ${ }^{1}$ Insurance is a form of saving, a grouping of individuals for their mutual protection. There is no excuse for the taxation of purely mutual insurance companies, and stock companies should be taxed only on the net income or the amount distributed to the stockholders as dividends.

The taxation of corporations on net income is the only method which will be equitable to all. If we are to levy any $\operatorname{tax}$ on corporations, we must regard them as legal persons, not as associations of individuals, and tax them on the income earned. This tax on corporation incomes should be collected by that authority in whose jurisdiction it is earned. The time for a tax on the net income of corporations, however, is not yet ripe, because it is difficult to ascertain the amount of such income. Gross income, therefore, should be made the measure of the amount payable until it becomes possible to resort to the truer index of ability to pay. Taxes on capital are inequitable be-

1 Vide articles in Proceedings of Second International Conference on State and Local Taxation, Toronto, 1908, pp. 343 and 363. 
cause of the varying rate of returns. Administrative difficulties prevent resort to the taxation of net income. There remains only gross income as a basis for corporate taxation.

The Canadian Provinces, as we have seen, have laid most stress on the taxation of corporate capital. This in itself is inequitable. The Provinces, however, tax not only the capital used within their respective jurisdictions but the total capitalization of the company. It is true that the rates are low and that this double taxation does not impose any great burden on the corporations affected. But the system is unscientific and inequality must follow as more emphasis is laid on this source of revenue. Each Province should tax corporations on the gross income earned within its jurisdiction. The proportion of the total gross earnings of a corporation taxable by each authority can be ascertained according to some index, such as mileage in the case of railways, or by co-operation on the part of the several jurisdictions under which the company operates. Such co-operation will make possible, not only the proper division of earnings, but also the devising of methods of ascertaining the total amount of earnings. The Provinces are now in a stage of industrial development which calls for the immediate institution of a proper system of tax regulation through centralization ${ }^{1}$ within each Province and co-operation between the several Provinces. Canada's problems are now forming and regulation cannot begin too soon.

Vide infra, ch. xii. 


\section{CHAPTER $\mathrm{X}$}

\section{Provincial Taxation-Succession Duties}

ALL seven of the older Provinces adopted their first acts providing for the taxation of inheritances during the three years I892-4. Ontario led by the passage of an act on April I4, I892, and was followed in the same year by Quebec, Nova Scotia and New Brunswick. Manitoba came next in 1893, closely followed by Prince Edward Island and British Columbia in 1894 . Inheritance taxes were provided for in 1903 in an ordinance of the Northwest Territories, the provisions of which are still in force in the two new Provinces, Saskatchewan and Alberta.

Ontario's first act ${ }^{2}$ was passed for the purpose of providing a special fund for the support of insane asylums and other charitable institutions, and all revenues derived from the "succession duties" were used for this purpose. It was applicable only to amounts in excess of $\$ 100,000$ when bequeathed in a direct line and in excess of $\$ 10,000$ when passing to collateral relatives or to strangers. Bequests to one person not exceeding $\$ 200$ in value were made exempt as well as those made for religious, charitable and educational purposes. The rates on direct heirs were two and one-half per cent on amounts between $\$ 100,000$ and $\$ 200,000$ and five per cent when the amount passing exceeded $\$ 200,000$. Collateral relatives paid five per cent and strangers ten per cent on all bequests in excess of the exemption of $\$ r o, 000$. These rates were applicable to real

155 Victoria, c. 6. 
and personal property of every description and to "every estate or interest therein capable of being devised or bequeathed by will or of passing on the death of the owner to his heirs or personal representatives."

This Succession Duty Act has been amended from time to time; the chief amendments being added in $1905,{ }^{1}$ when the exemption of property passing in the direct line was reduced to $\$ 50,000$ and a more elaborate scale of rates graduated from one per cent to five per cent was provided for all exceeding this amount. This measure also introduced an additional tax on large amounts passing to one person.

In $1907,{ }^{2}$ the various amendments were consolidated in one act and several changes were made. Life insurance, when not exceeding $\$ 5,000$ and when passing to a direct heir, is not subject to taxation; the exemption of property passing to one person was increased from $\$ 200$ to $\$ 300$; and that of bequests for religious, charitable and educational purposes was limited to those made to associations or persons within the Province. Estates not exceeding $\$ 50,000$ when bequeathed to direct heirs and $\$ 10,000$ to others are still exempt. The revenue derived from succession duties is no longer turned over to the support of charitable institutions but becomes a part of the general Provincial fund.

The rates on bequests to direct heirs ${ }^{3}$ are as follows:

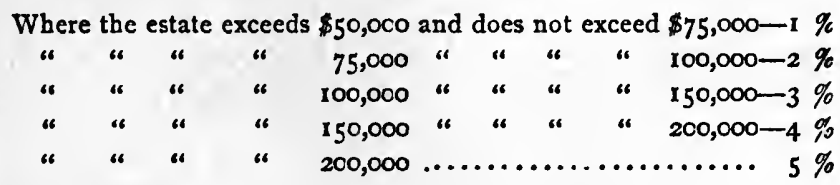

15 Edward VII, c. 5.

27 Edward VII, c. 10.

- Grandparents, parents, husband, wife, children, sons-in-law and daughters-in-law. 
When the amount passing to one person is in excess of $\$ 100,000$, the following additional rates are levied:

\begin{tabular}{|c|c|c|c|c|c|c|c|c|c|c|}
\hline Whe & $\operatorname{tn}$ & No & ceeds & $\$ \mathrm{rco}, \mathrm{coO}$ a & tac & $10 \mathrm{e}$ & & xceed & $\$ 200,000-1$ & y. \\
\hline " & “ & “ & " & 200,000 & “ & “ & “ & "4 & $400,000-11 / 2$ & 40 \\
\hline 4 & “ & " & " & 400,000 & “ & " & $"$ & “ & $600,000-2$ & $\%$ \\
\hline “ & $“$ & “ & " & 600,000 & “ & $"$ & $"$ & " & $800,000-21 / 2$ & $\%$ \\
\hline “ & “ & “ & “ & 800,000 & "“ & as & $"$ & $"$ & $1,000,00 c-3$ & \\
\hline " & " & "4 & " & $\mathrm{I}, \mathrm{OCO}, \mathrm{COO}^{1}$ & “ & " & “ & " & $1,200,000-4$ & \\
\hline “ & "6 & " & "1 & $\mathrm{I}, 200, \mathrm{COO}^{\mathrm{I}}$ & & & & $\cdots$ & ........ & \\
\hline
\end{tabular}

When the aggregate value of an estate is in excess of $\$ 10,000$ a tax of five per cent is imposed on the amounc passing to lineal ancestors more remote than parent or grandparent, or to brothers or sisters, uncles or aunts, or to any descendant of such. An additional rate varying from one per cent to five per cent is imposed when the amount bequeathed to any one of these persons exceed.s $\$ 50,000$. The minimum of one per cent is for amounts between $\$ 50,000$ and $\$ 100,000$, the maximum of five per cent for amounts over $\$ 450,000$, the percentage increasing at the rate of one-half of one per cent per $\$ 50,000$.

Amounts passing to distant relatives or to strangers in blood are taxed ten per cent when the aggregate value of the estate exceeds $\$ 10,000$.

The Nova Scotia act imposing succession duties was passed on April 30, 1892, ${ }^{2}$ and, with certain minor amendments, is still in force. The terms of the act are almost identical with those of the Ontario act adopted a few weeks previously, the chief difference being in the matter of exemption. The tax was levied in Nova Scotia on all estates exceeding $\$ 25,000$ passing to direct heirs and exceeding $\$ 5,000$ for others. The similarity in the acts is

1 Before 1909 (9 Edward VII, c. 12) three per cent was levied on amounts in excess of $\$ 800,000$.

55 Victoria, c. 6. 
also seen in the purpose for which the tax was levied, the proceeds in Nova Scotia being devoted, as in Ontario, to the support of Provincial asylums and hospitals.

The rates are the same as those first imposed in Ontario, except that they apply to estates of smaller value. Direct heirs pay two and one-half per cent when the value of the estate is greater than $\$ 25,000$ but less than $\$ 100,000$, and five per cent when the value of the estate exceeds $\$ 100,000$. Collateral relatives pay five per cent and strangers in blood ten per cent. The exemption of property passing to one person was $\$ 200$ in the original act. This has since been raised to $\$ 500 .^{1}$

The Quebec Legislature, on June 24, I892,2 adopted "an act respecting duties on successions and on transfers of real estate." The transfer tax was at the rate of one and one-half per cent on the sale or transfer of immoveables, except in the case of donations in the direct line not exceeding $\$ 5,000$ in value. This was reduced to one per cent in 1894 and abolished in $1897 .^{3}$

Property bequeathed in direct line was required to pay a tax of one per cent when the total value of the estate, after the payment of all debts and expenses, exceeded the sum of $\$ 10,000$. Collateral relatives paid three per cent, six per cent or eight per cent, according to the degree of relationship, and strangers in blood paid ten per cent. Two years later, ${ }^{4}$ these rates were amended by the introduction of a graduated scale for direct heirs and the amount of the exemption was reduced. Estates the net value of which did not exceed $\$ 3,000$ were exempt and those of greater

${ }^{1}$ Rev. Stats., N. S. (1900), c. 14.

${ }^{2}$ 55-6 Victoria, c. 17.

${ }^{8} 57$ Victoria, c. 16 and 60 Victoria, c. 12.

457 Victoria, c. 16. 
value were taxed at rates rising from one-half of one per cent for amounts between $\$ 3,000$ and $\$ 5,000$ to three per cent for amounts in excess of $\$ 200,000$. The rates on collateral relatives were also amended by the introduction of a new class with a five per cent tax.

The act of $1906^{1}$ with amendments is now in force. It has not only increased the rates materially but has also introduced an elaborate scale graduated according to the degree of relationship, the total value of the estate and the amount passing to one person. Direct heirs are allowed an exemption of $\$ 5,000$ and the following rates are imposed on amounts in excess of this. ${ }^{2}$ When the value of the estate is

\begin{tabular}{|c|c|c|c|c|c|c|c|}
\hline From & $\$ 5,000$ to & $\$ 10,000$ & on & all & over & $\$ 5,00$ & $00-1 \%$ \\
\hline “ & 10,000 to & 50,000 & “ & “ & “ & “ & $-\mathrm{I} 1 / 4 \%$ \\
\hline “ & 50,000 to & 75,000 & “ & “ & “ & “ & $-\mathrm{I} / 2 \%$ \\
\hline “ & 75,000 to & 100,000 & “ & “ & “ & “ & $-2 \%$ \\
\hline “ & 100,000 & 150,000 & “ & “ & “ & “ & $-3 \%$ \\
\hline “ & I 50,000 & 200,000 & “ & “ & “ & “ & $-5 \%$ \\
\hline
\end{tabular}

When the amount passing to any one person in the direct line exceeds $\$ 100,000$, additional duties must be paid according to the following scale :

$$
\begin{aligned}
& \text { On amounts from } \$ 100,000 \text { to } \$ 200,000-1 \% \\
& \text { " " " } 200,000 \text { to } 400,000-11 / 2 \% \\
& \text { " " " } 4400,000 \text { to } 600,000-2 \% \\
& \text { " " " } 600,000 \text { to } 800,000-21 / 2 \% \\
& \text { " " over } 800,000 \ldots . . . . .3 \%
\end{aligned}
$$

16 Edward VII, c. II. The amending acts are 7 Edward VII, c. I4, 9 Edward VII, c. 2I, and I George V, c. I2.

2 There is now (March, I9I2) a bill before the Legislature for the exemption of estates passing in direct line which do not exceed $\$ 15,000$ in value. Should this pass, the one per cent rate will disappear and one and one-fourth per cent will be levied on estates between $\$ 15,000$ and $\$ 50,000$ in value, after deducting $\$ 5,000$. 
The rates on amounts passing to collateral relatives are five per cent for brothers or sisters or their descendants, six per cent for uncles or aunts or descendants, seven per cent for great uncles or great aunts or their descendants, and eight per cent for any other collateral relatives. These rates apply when the amount passing does not exceed $\$ 10,000$, one-half of one per cent being added when in excess of $\$ 10,000$ in each case, except the last, where the rate becomes nine per cent.

Amounts passing to strangers in blood are taxed at the rate of ten per cent, and additional rates, varying from one per cent on amounts between $\$ 50,000$ and $\$ 100,000$ to five per cent on amounts in excess of $\$ 450,000$, are imposed when the total bequest to a collateral relative or a stranger exceeds $\$ 50,000$.

The amending act of 1907 imposed an additional duty of five per cent on all property devolving to a person domiciled outside of the British Empire or to an association having its head office outside of the Empire. This surtax, however, has been repealed. ${ }^{1}$

New Brunswick is the fourth of the Provinces which imposed a duty on successions in 1892 . Its act, which is still in force, ${ }^{2}$ bears a close resemblance to the first Succession Duty Act of the Ontario Legislature. Amounts passing to one person and not exceeding $\$ 200$ are exempt and there is the usual exemption of property bequeathed for religious, charitable and educational purposes. Estates, the value of which does not exceed $\$ 50,000, \$ 10,000$ and $\$ 5,000$, and passing to direct heirs, to near collateral relatives and to distant collateral relatives or strangers, respectively, are free from taxation. When the aggregate

1 I George V (IgII), c. I2, S. I.

Consol. Stats. (1903), c. I7. 
value of a property passing to direct heirs exceeds $\$ 50,000$, the rate is one and one-fourth per cent up to $\$ 50,000$ and two and one-half per cent on the amount in excess. Should the aggregate value exceed $\$ 200,000$, five per cent on the whole value is paid. Properties exceeding $\$ 10,000$ in value and passing to near collateral relatives pay five per cent, and those with a value in excess of $\$ 5,000$ passing to distant collateral relatives or to strangers, ten per cent of the whole value. When the beneficiary resides outside of the Province the rate is doubled.

Manitoba's first act ${ }^{1}$ for the imposition of succession duties made no attempt to graduate the rates according to degree of relationship. Relationship was considered only when estates of a value not exceeding $\$ 25,000$ were exempted when passing in a direct line, while other heirs were required to pay a tax on estates of a value exceeding $\$ 4,000$, and in the exemption of property not in excess of $\$ 7,000$ passing in a direct line to one person. The rate of duty was graduated from one per cent on amounts under $\$ 25$,000 to ten per cent on bequests of $\$ r, 000,000$ or more. An amendment of $1905^{2}$ has increased these rates by reducing the amounts to which they are applicable.

Prince Edward Island's act of $1894^{3}$ is still in force. The exemptions are estates passing to direct heirs and not exceeding $\$ 10,000$ in value, those passing to other heirs and not exceeding $\$ 3,000$ in value and bequests for religious, charitable, and educational purposes. Direct heirs pay one and one-half per cent on the whole value of the estate when it exceeds $\$ 10,000$ but is less than $\$ 50,000$, and two and one-half per cent when it exceeds $\$ 50,000$.

${ }^{1} 56$ Victoria, c. 31 .

24-5 Edward VII, c. 45.

37 Victoria, c. 5 . 
Collateral relatives pay two and one-half per cent and distant relatives or strangers pay seven and one-half per cent on estates of a value exceeding $\$ 3,000$.

British Columbia's Succession Duty Act of $1894^{1}$ levied a rate graduated from one per cent on amounts up to $\$ 100,000$ to five per cent on amounts in excess of $\$ 1$,000,000. Property passing in direct line, however, was required to pay only one-half of these rates. The exemptions were estates of $\$ 25,000$ passing to direct heirs and $\$ 5,000$ to others. The rates, which have been amender from time to time, ${ }^{2}$ are now as follows:

Where the aggregate value of the bequest in direct line exceeds $\$ 25,000$,

$I^{1} / 2 \%$ of the whole value, up to and including $\$ 100,000$.

$2 \frac{1}{2} \%$ of the whole value, when between $\$ 100,000$ and $\$ 200,000$.

$5 \%$ of the whole value, when in excess of $\$ 200,000$.

Where the aggregate value of the property exceeds $\$ 5,000$ and it passes to collateral relatives,

$5 \%$ of the whole value of the property so passing.

Where the aggregate value of the property exceeds $\$ 5,000$ and it passes to distant relatives or to strangers,

10\% of the whole value of the property so passing.

The Northwest Territories made provision in 1903 for the taxation of inheritances in an ordinance ${ }^{3}$ which imposed rates closely following those of British Columbia. ${ }^{4}$ The exemptions were estates of $\$ 25,000$ in direct line and

157 Victoria, c. 47.

62 Victoria, c. 68 (1899); 64 Victoria, c. 35 (I901); 7 Edward VII, c. 39 (1907); 8 Edward VII, c. 46 (1908).

3 1903, session 2, c. 5.

- Act of 1899 (62 Victoria, c. 68). 
$\$ 5,000$ to others, and individual shares not in excess of $\$ 5,000$ passing to direct heirs and $\$ 200$ to others. The tax levied by this ordinance was to be paid only on the amount in excess of the exemption. ${ }^{1}$ These provisions are now in force in the two new Provinces, Alberta and Saskatchewan, with the exception that the rates apply to the full value of estates the aggregate value of which exceeds $\$ 25,000$ and $\$ 5,000$ when passing to direct heirs, or to others, respectively.

The Provinces of Ontario and Quebec stand out as those having the most elaborate systems. Here we find graduation not only according to the total value of the property and the degree of relationship, but also according to the amounts bequeathed to one person. British Columbia, Saskatchewan, Alberta and the three Maritime Provinces provide for very simple progressive rates according to the degree of relationship, and in the case of direct heirs, according to the amount passing, while Manitoba stands alone in graduating the rates only according to the amount passing. The table below will enable the reader to make a rough comparison of the rates in force in the Provinces.

Probate fees, ${ }^{2}$ the amounts of which vary in the several Provinces, must be paid in addition to the succession duties. In Ontario, the rate is about $\$ 1.50$ for each $\$ 1,000$ of the estate, two-thirds of which amount goes to the Provincial Treasury, the remaining one-third being a fee for the probate court judges. Nova Scotia $^{3}$ has a schedule of fees, payable to probate judges and registrars, which imposes uniform rates for all estates of a value above $\$ 4,000$. New

1 This is true also of the British Columbia tax imposed by 62 Victoria, c. 68 , which was amended in this respect by 64 Victoria, c. 35 (I90I).

2 Vide West, The Inheritance Tax, pp. 81 et seq.

' Rev. Stats. of N. S., c. 185 (p. 844). 


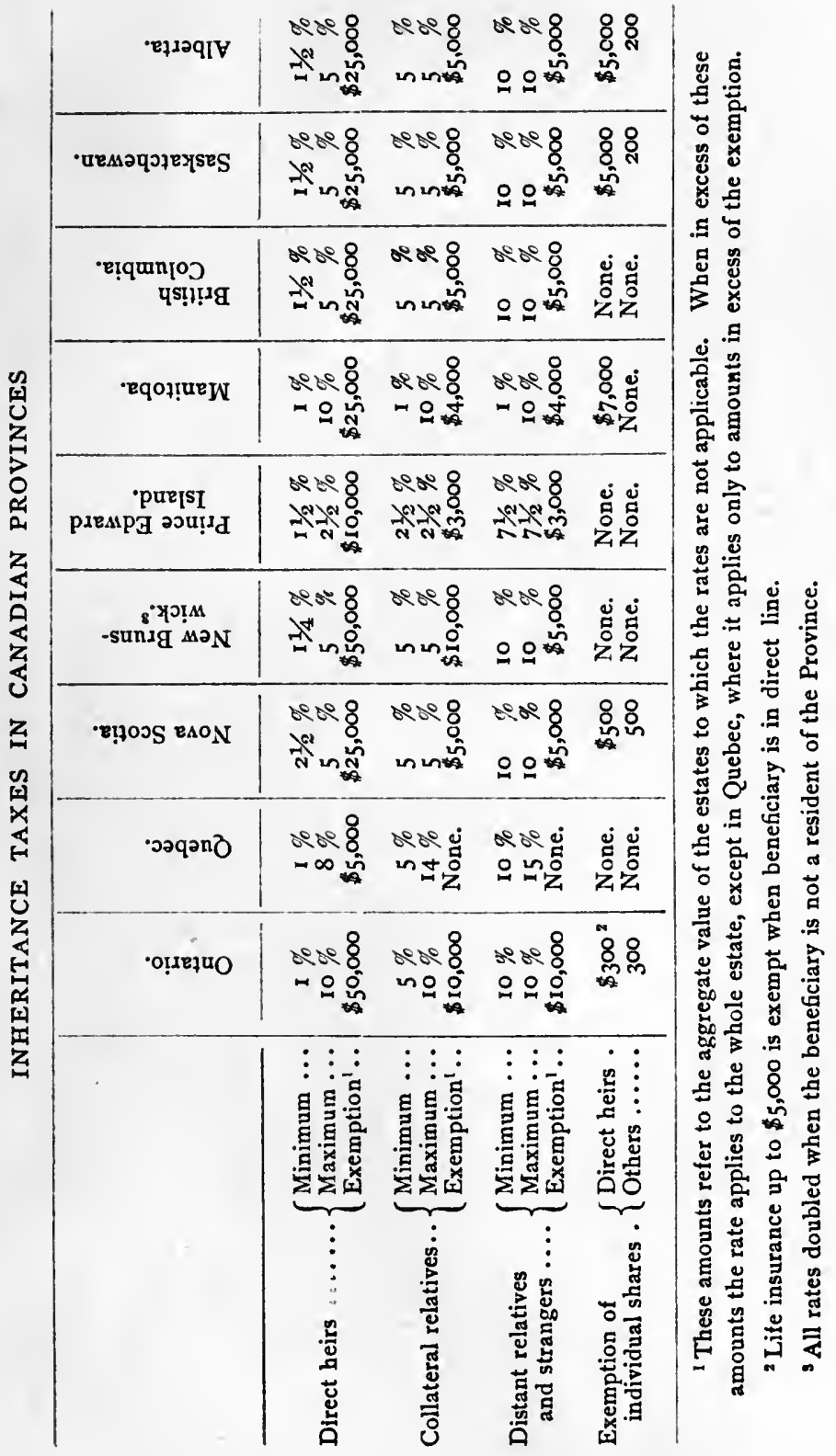


Brunswick ${ }^{1}$ has established a "Probate Fee Fund," out of which are paid the salaries of probate judges and registrars. This fund is formed out of the revenue derived from a system of fees which are progressive for estates up to $\$ \mathrm{I}, 000$ but regressive for all estates having a value exceeding this amount. There are also various court and proctors' fees. In Manitoba ${ }^{2}$ provision is made for various clerk's and registrar's fees, and for a judge's fee slightly regressive up to $\$ 4,000$ and proportionate for all estates in excess of this. British Columbia ${ }^{3}$ imposes the highest probate fees. These are one per cent on the value of an estate passing to father, mother, brother or sister, and five per cent to all others, except wife and child, from whom no payment is exacted.

The Canadian Provinces have had to grapple with the usual problems caused by conflict of jurisdiction. Ontario's first Succession Duty Act made taxable all property situated within the Province where the deceased was domiciled in the Province or had been so domiciled within five years previous to decease. In I $895,{ }^{4}$ the rates were also applied to all property situated within the Province regardless of the domicile of the deceased. It was also enacted by this measure that property brought into the Province for distribution was liable to taxation whether the deceased had been a resident or not, but only when such property had not already been subject to duty equal to or greater than that imposed by the Ontario act. This proviso was due to the provisions of England's Finance Act of 1894, under which the amount paid as succession duties in the colonies by estates of residents of the United Kingdom is deducted from the sum payable to the English Gov-

16 I Victoria, c. 35.

Vide 7 Edward VII, c. 3I.
2 Rev. Stats. Man., c. 37.

58 Victoria, c. 7. 
ernment only when British property is similarly treated by the colonial Governments. ${ }^{1}$ The act of $1905^{2}$ made taxable all property in the Province regardless of the domicile of the deceased and all personal property where the deceased was domiciled in Ontario at time of death. A reciprocal clause was added whereby allowance was made for duty paid on personal property situated in " any country, state or British possession " which makes similar provisions for property situated in Ontario. This clause differs from that introduced in 1895 , in that the allowance is made to depend on reciprocity on the part of other jurisdictions. Allowance is now made for duty paid in the United Kingdom and in five of the Canadian Provinces. ${ }^{8}$ The Succession Duty Act of $1909^{4}$ makes subject to duty all property situated in Ontario passing on the death of any person, whether the deceased was at the time of his death domiciled in Ontario or elsewhere. This omission of personal property situated outside of the Province where the deceased was domiciled in Ontario at the time of his death was due to a decision of the Privy Council in 1908 declaring ultra vires a tax levied on property locally situate outside of the Province. ${ }^{5}$

The Quebec act ${ }^{\circ}$ applies to all property situated within the Province and to all personal property of a person who was domiciled in the Province at the time of his death, whether or not such property is situated in Quebec. In Nova Scotia the Succession Duty Act ${ }^{7}$ applies to all property situated in the Province regardless of the residence of the deceased. Property brought into the Province

1 Vide West, op. cit., p. 85.

B. C., Man., N. B., N. S., Sask.

4 Edward VII, c. 12, s. I.

- 6 Edward VII, c. II.
25 Edward VII, c. 6.

Vide infra, pp. 150-I.

Rev. Stats. (1900), c. 14 
for distribution on which duty has already been paid is liable only for the difference if such duty is less than that of Nova Scotia. All property in the United Kingdom is free from duty when it is there subject to taxation. This provision is also found in the New Brunswick act, ${ }^{1}$ which applies, in general, to all property situated in the Province and to all personalty outside of the Province where the deceased was a resident of New Brunswick at the time of his death, as well as to property outside of the Province owned at the time of his death by a non-resident, if such property is transferred or devised to a person or persons residing in New Brunswick. An Order-in-Council of June 14th, 1907, reciprocating the provisions of the Ontario Act, has somewhat modified these clauses. Prince Edward Island, in $1908,{ }^{2}$ also introduced the reciprocal provision for property situated outside of the Province.

British Columbia's act is declared to apply to all property situated in the Province whether or not the deceased was there domiciled at the time of his death, and to "all stocks, bonds, shares, debentures and other securities for money no matter where the corporation or other body issuing the same may be located belonging to the estate of a person " domiciled in the Province at the time of his death. It also has a reciprocal provision allowing for the amount of duty paid elsewhere. The Ordinance of the Northwest Territories, ${ }^{4}$ the provisions of which are still in. force in Saskatchewan and Alberta, applies the duty on successions to all property within the Territories and to all personal property belonging to the deceased if domiciled therein. It also provides that, where duty has been paid elsewhere, the difference only shall be paid when such duty is less than that imposed in the Territories.

1 Consol. Stats. (1903), c. 17.

3 Edward VII, c. 39 .
28 Edward VII, c. 12.

- 1903 , session 2, c. 5 . 
Manitoba's first act for the imposition of duties on successions applied the tax to all property situated in the Province and to all personal property of a deceased resident brought into the Province for distribution, except when duty has been paid on such property where situated, in which case only the difference is to be paid if the duty elsewhere is less than that imposed in Manitoba. The Legislature of the Province amended these provisions in I $909^{1}$ so as to define the limitations on the right to tax corporate securities and for the purpose of avoiding double taxation of personal property of a deceased resident which is situated outside of Manitoba. These clauses, however, were repealed in $1910,{ }^{2}$ when the act was declared not to apply to "movable property locally situate out of this Province, and any interest therein and income therefrom, where the owner was domiciled in this Province at the time of his death."

The principle of mobilia sequnntur personam has been upheld in several decisions of the Canadian courts, following those of the English Privy Council regarding Australian cases. ${ }^{3}$ The first decision on the question of situs $v s$. domicile was rendered in $1898,{ }^{4}$ when it was declared that, where the deceased resided outside of Ontario and the property within the Province falls below the amount exempted, no succession duty is to be paid. This principle was again maintained in Lambe vs. Manuel, ${ }^{5}$ where the courts decided that the taxes imposed by the Quebec Succession Duty Act can have no application to that part of a succession devolving under the law of Ontario, although

19 Edward VII, c. 69.

2 Io Edward VII, c. 70.

Blackwood $v s$. Regina, 8 A. C. 94 ; Henty $v s$. Regina, 1896 A. C. 567.

429 Ont. Rev., 565.

${ }^{5} 18$ Que. S. C. 184 , and 1903 A. C. 68. 
the property in question consisted of bank shares registered in Montreal and a loan to a person domiciled in Quebec.

Money on deposit in a bank of any Province and belonging to a person domiciled outşide of the Province has been declared dutiable in several cases. The first decision on this point was rendered in Ontario in $1900,{ }^{1}$ when it was declared that succession duty was payable on nonnegotiable deposit receipts held by a foreigner at the time of his death in a foreign country and payable after notice at branches of a Canadian bank in Ontario. The payment of these deposit receipts could be enforced, it was held, only by a personal representative in Ontario and duty was payable on property which properly could be administered only in Ontario. A British Columbia decision in $1902^{2}$ follows the same reasoning, as did also the New Brunswick courts in The King vs. Lovitt, ${ }^{3}$ declaring dutiable in that Province deposit receipts payable in St. John and belonging to a person domiciled in Nova Scotia. The latter case, however, was reversed upon appeal to the Supreme Court of Canada, where the property, a debt due from the bank to the deceased, was declared to have its situs in Nova Scotia and to be dutiable in that Province. ${ }^{4}$ The court, in rendering decision, questioned that given in the Ontario case cited above. It remains to be seen whether the higher Canadian courts will uphold a tax on bank deposit receipts payable to a person domiciled in a foreign country, as were those in the Ontario and British Columbia cases.

One of the most important decisions in connection with Canadian succession duties was rendered by the English Privy Council in 1908. ${ }^{5}$ The property in question consisted

1 3I O. R., 340 (Att'y-Gen'l. of Ont. vs. Newman).

2 In re Estate of Scott McDonald, 9 B. C. R., 174

37 N. B. R., $558 . \quad 43$ S. C. R., 106 (March, 1910).

5 Woodruff vs. Att'y.-Gen'l. for Ont., I908 A. C. 508. 
of bonds and debentures of various municipalities in the United States deposited in trust in the city of New York for the sons of the deceased at two different periods, ten years and two years before his death in 1904. Upon the death of the depositor these securities were to be delivered to his sons, to whom the interest was also payable as it became due. The Court held that the property was locally situate outside the Province of Ontario, where the deceased was domiciled at the time of his death, and that the delivery.under which the transferees took title was made in the State of New York. "The powers of the Provincial Legislatures being strictly limited to 'direct taxation within the Province,' any attempt to levy a tax on property locally situate outside the Province is beyond their competence." The securities were, therefore, not taxable by Ontario.

Personal property of an individual domiciled at the time of his death in any Province is still subject to the payment of succession duty, regardless of the location of such property, the principle of mobilia sequuntur personam being followed to determine situs in cases where the property must be brought into the Province for administration. The Ontario courts recently declared dutiable certain mortgages on real estate in Michigan which were in the custody of the owner in Ontario at the time of his death and which were in the list of properties held by the executors upon application for probate in Ontario. ${ }^{1}$ The Court gave as its opinion that the rule laid down in 1908 by the Privy Council probably would have prevailed if the instruments had not been located in Ontario.

The law at present, therefore, seems to be that only property situated within a Province can be taxed by that Province, and that property is so situated when it must be

1 Treasurer of Prov. of Ont. vs. Pattin, 220 O. L. R, 184 
brought into the Province for probate. There is, however, no question as to the right of the Provinces to require that all property of the deceased wherever situated should be taken into consideration in order to estimate the "aggregate value" of the estate. This provision is made in the succession duty acts of all the Provinces, the aggregate value being ascertained for the purpose of deciding whether or not an estate is dutiable, and to determine the rate of duty, if the estate is subject to the act. 


\section{CHAPTER XI}

\section{The Separation of Sources of Revenue}

ONE of the most striking features of Provincial and local taxation in Canada is the separation of sources of revenue which exists in all nine of the Provinces. This division of the field of taxation, with the resulting mutual independence of the Provincial and municipal authorities, has enabled Canada to avoid one of the evils which has long beset the tax reformers of the American states, namely, the apportionment of taxes to the localities by the central authorities. This apportionment is undesirable because of the difficulty of providing a basis of division which will not result in a manipulation of assessment values or in other abuses. Several of the American states, ${ }^{1}$ for want of such a basis of apportionment, have abolished state taxes on general property and have confined the central authorities to such sources as corporation and inheritance taxes and licenses. The direct imposition of taxes on property locally assessed has not been attempted, the danger of unjust double taxation being too great and the necessary machinery too expensive. The natural course to follow, therefore, is to abandon completely any attempt to raise state revenues from sources recognized as falling within the scope of local taxation.

This separation of sources, which is very slowly taking place in the United States, has been effected in Canada by a process of historical development. The majority of the

${ }^{1}$ Notably New York; others are Penn., N. J., Conn., and Del. I53] 
people of Lower Canada were opposed, as we have seen, ${ }^{1}$ to all forms of direct taxation, preferring to derive the Provincial revenues from indirect taxes bearing most heavily on the commercial element, which was largely British. Whatever local improvements were carried out were paid for by the central governmental body, there being no provision for general local taxation before 1845 . Upper Canada ${ }^{2}$ instituted a system of local assessments as early as 1793. The United Empire Loyalists, who had settled in this Province, were somewhat familiar with local self-government through the beginnings which had been made in this direction before the American revolution, and there was so little surplus in the revenues of the central body that a system of local assessments was forced upon the localities as the only means of providing the various improvements so urgently required.

The revenues in both Upper and Lower Canada were derived from three sources: Imperial duties, Provincial duties and certain casual and territorial revenues. The customs duties were collected in Lower Canada and the upper Province experienced considerable difficulty in obtaining a just division. The latter received only one-eighth of the duties collected during the years preceding 1824 , when the proportion was increased to one-fifth. ${ }^{8}$ The result was that with a growing population there was a continued deficit, which could not be met by a levy on the localities because of their difficulty in raising sufficient revenue to effect necessary improvements. The Provincial Assembly, on the contrary, often was forced to vote funds

1 Vide supra, p. 25.

2 Vide supra, p. 32.

- Bradshaw, Self-Government in Canada, p. 59. The proportion was gradually increased and in 1840 was two-fifths (ibid., p. 270). 
in aid of the localities. In the earlier years, ${ }^{1}$ both Provinces looked to the Imperial Government for aid, rather than to direct taxation.

Lord Durham, in $1840,{ }^{2}$ speaking of Upper Canada, states that "it will soon be obliged to have recourse to direct taxation to meet its ordinary civil expenditure." This, however, was avoided by the reorganization of the governmental system of Canada by the Act of Union in I 840 , and by the institution of systems of municipal government in both Provinces, thereby relieving the central bodies of large items of expenditure. There was little danger of resort to direct taxation by the Provincial authorities after the union, because of the sufficiency of revenue from other sources.

The British North America Act of 1867 gave to the Federal Government the two great sources of revente, the customs and the excise, and limited the Provincial Governments to licenses and direct taxation within the Province. The latter source of revenue being at that time wholly in the hands of the municipalities, and the revenue from the former being comparatively small, it was felt by the framers of the Act that some provision should be made to fill the gap in the Provincial budgets caused by the withdrawal of the right of indirect taxation. Another point which had to be considered was that the four Provinces, which entered Confederation in 1867 , had contracted debts by expenditures on canals and other necessary works of a public, nature, many of which would fall within the jurisdiction of the Federal Government under the proposed arrangement. It was therefore provided that the Central Government should assume the debts of the Provinces and should pay to each an annual subsidy to meet expenses.

1 Vide supra, p. 13.

2 Report, pp. I35-6. 
The debt assumption ${ }^{1}$ in 1867 was $\$ 62,500,000$ for Quebec and Ontario, $\$ 8,000,000$ for Nova Scotia and $\$ 7,000$,ooo for New Brunswick. The debt of the Province of Canada, divided by the Act into Quebec and Ontario, was in excess of the amount of debt allowance, while that of the two lower Provinces was smaller. It was, however, thought advisable to assume the above sums, calculated on a population basis, and to effect an arrangement by which the first two Provinces were together required to pay interest at the rate of five per cent on the amount by which the debt of the Province of Canada exceeded the amount allowed, and New Brunswick and Nova Scotia were to receive interest at the same rate on the amount by which their debts fell short of $\$ 7,000,000$ and $\$ 8,000,000$, respectively.

This arrangement for debt assumption has been amended several times, the changes being made for three reasons, the desirability of removing inequalities, the admission of new Provinces to Confederation and the necessity of grant. ing further aid to the Provincial finances. It was found necessary, in 1869 , to increase Nova Scotia's debt allowance to $\$ 9,186,756$, in order to reconcile her to the Union. Manitoba entered Confederation in $1870,{ }^{2}$ with a debt allowance of $\$ 472,090$, all of which amount was an assumed indebtedness on which the Dominion Government was required to pay interest at five per cent. British Columbia entered in $187 \mathrm{r},{ }^{3}$ with a debt of $\$ 1,666,200$, and Prince

\footnotetext{
1 Much of the information given in the pages on debt assumption were obtained from an article, entitled "Sketch of Canadian Financial History," by the Hon. Geo. E. Foster, late Minister of Finance of the Dominion, in Hopkins' Encyclopedia of Canada, v, 3or.
}

- 33 Victoria, c. 3.

${ }^{3}$ Order-in-Council, May 16, 1871. 
Edward Island in $1873,{ }^{1}$ with $\$ 4,927,060$. The Federal Government in 1873 assumed the excess of the debts of Quebec and Ontario, amounting to $\$ 10,506,089$ and, in order that there should be no disturbance of the balance established in 1867 , proportional increases were allowed to Nova Scotia, New Brunswick, Manitoba, and British Columbia.

The needs of the Provinces, especially of Quebec, led to another readjustment in $1884,{ }^{2}$ whereby the local Governments were placed in the same position as if the arrangement of 1873 had been made in $1867 .^{3}$ Two years later, an increase in the assumed debt of Manitoba was granted, bringing the total debt allowance of this Province up to $\$ 3,775,606$. The only change made in the arrangements for debt assumption since 1886 is the addition of \$16.215,000 for Alberta and Saskatchewan in 1905. ${ }^{4}$ The total amount assumed by the Dominion is $\$ 125,645,148$, which is distributed among the various Provinces as follows:

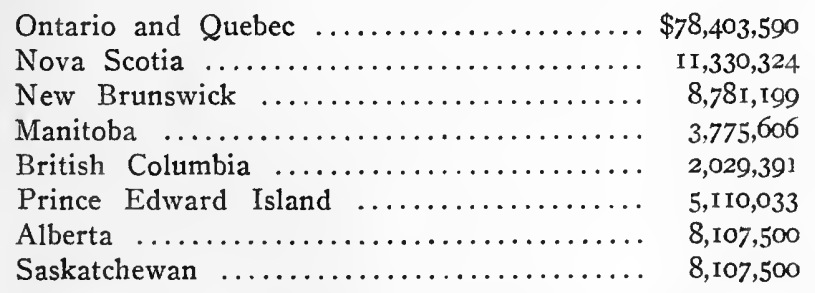

The Federal Government, in addition to the relief granted the local bodies by debt assumption, pays annual subsidies

1 Order-in-Council, June 26, 1873.

37 Victoria, c. 4.

3 Vide Debates. of Dom. House of Coms., 1884, pp. I584-5.

${ }^{4}$ Dom. Stats., 4-5 Edward VII, cc. 3 and 42 . The amount of debt allowed was calculated on a basis of $\$ 32.43$ per head of population. (Coms. Deb., 1905, p. 1438). 
to each of the Provinces, the amount of which was fixed according to the expenditures of the several Provinces entering Confederation. These subsidies are of two kinds, a specific sum to meet the expenses of the Government and Legislature, and a grant of 80 cents per head of population. Under the provisions for the payment of the first, the following sums were granted to the original four Provinces and to those later entering the Union.

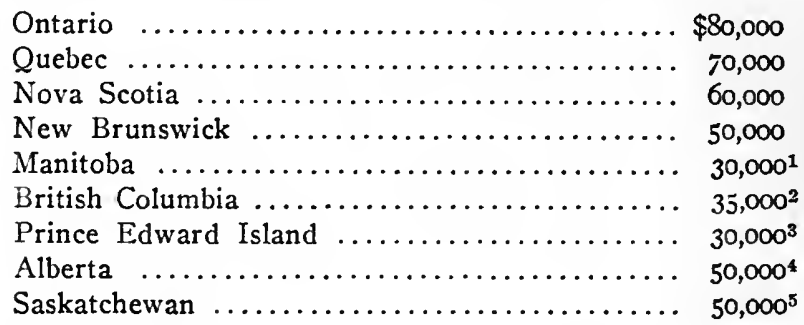

The annual grant per capita was based, in the case of Ontario and Quebec, on the population as ascertained by the census of 1861 , while in Nova Scotia and New Brunswick it was calculated on the population as ascertained "by each subsequent decennial census until the population of each of those two Provinces amounts to 400,000 souls, at which rate such grant shall thereafter remain." " New Brunswick was given an additional annual allowance of $\$ 63,000$ for a period of ten years. Manitoba, in 1870 , was granted an annual subsidy of 80 cents per capita on an estimated population of 17,000 . This was increased in $1882,{ }^{7}$ by taking the estimated population as 150,000 .

1 Increased to $\$ 50,000$ in 1882 (45 Victoria, c. 5 ).

- Order-in-Council, May 16, 1871.

- Order-in-Council, June 26, 1873.

- Dom. Stats., 4-5 Edward VII, c. 3.

${ }^{6}$ 4-5 Edward VII, c. 42.

- B. N. A. Act, article II8.

74 Victoria, c. 5. 
British Columbia was allowed a like rate per capita on an assumed population of 60,000 , and Prince Edward Island's grant in 1873 was based on a population of $94,02 \mathrm{I}$, as shown by the census of $187 \mathrm{I}$. In all three of these new Provinces, the per capita grant was to increase with the growth of population, as shown by each subsequent decennial census, until 400,000 was reached, after which the grant was to become fixed. New Brunswick's subsidy received an increase of $\$ 150,000$ in 1873 because of the abolition by the Treaty of Washington of the export duty on lumber, the right to levy which had been granted this Province in $1867 .^{1}$ The struggling Province of Prince Edward Island was also given an increase of $\$ 20,000$ in $1887 .{ }^{2}$ I887. ${ }^{2}$

An important point in connection with the independence of the financial systems of the Provinces is the provision allowing Ontario, Quebec, Nova Scotia and New Brunswick to retain all lands, mines, minerals and royalties, situated within their respective jurisdictions. This source of revenue has furnished a large percentage of the income of these Provinces. ${ }^{3}$ British Columbia was also permitted to retain its public lands, with the exceptions of those to be conveyed to the Dominion Government to aid in the construction of a railway, in consideration of which the Province receives an annual subsidy of $\$ 100,000 .{ }^{4}$ The Province of Prince Edward Island had no Crown lands and was granted an annual payment of $\$ 45,000 .^{5}$ When Manitoba entered the Union in $1870,{ }^{\circ}$ it was provided that all un-

'B. N. A. Act, article I24. 50-51 Victoria, c. 8.

"Vide infra, statement in "Appendix."

- Order-in-Council, May I6, I87I.

- Order-in-Council, June 26, 1873.

- 33 Victoria, c. 3, s. 26. 
granted and waste lands in the Province should be vested in the Crown and administered by the Government of Canada. Twelve years later, ${ }^{1}$ when the specific grant and the per capita allowance of this Province were increased, an indemnity of $\$ 45,000$ for the want of public lands was also granted. This was increased, in $1885^{2}$, to $\$ 100,000$, and it was also provided that all the swamp lands of Manitoba should belong to the Province.

This policy of placing the administration of the Crown lands in the hands of the Central Government and allowing the Provinces an indemnity was followed in establishing the Provinces of Alberta and Saskatchewan. The Alberta and Saskatchewan Acts, in addition to providing for a specific sum and for the assumption of the Provincial debts, granted to each of the new Provinces a per capita rate of 80 cents on an estimated population of 250,000 and an annual sum in lieu of lands which was also based on population. The amount of the allowance per capita wa's to have been increased when the population should have exceeded 250,000 until the figure 800,000 was reached. The sum payable in lieu of public lands will be $\$ 375,000$ as long as the population is less than 400,000 , and a scale of amounts payable is provided for such time as the population shall exceed 400,000 , the maximum amount being $\$ 1,125,000$ for a population in excess of $1,200,000$. An additional annual sum of $\$ 93,750$ was granted to each Province for five years for the construction of public buildings. These terms, however, have been somewhat changed by the British North America Act of 1907.

An Interprovincial Conference ${ }^{3}$ was held at Quebec in December, 1902, for the purpose of petitioning for an in-

45 Victoria, c. 5 .

${ }^{2} 48-9 \cdot$ Victoria, c. 50.

- British Columbia not represented. 
crease in the annual subsidy. This Conference, as well as those held at Ottawa in January, 1903, and October, 1906, adopted a set of resolutions which were later embodied in an address presented to the English Parliament by the Senate and House of Commons of Canada. An Imperial statute $^{1}$ amending the British North America Act of 1867 was the result.

This amending act provided that there should be paid as subsidies to all the Provinces, which at that time were in the Dominion, annual amounts proportioned to population. The minimum fixed sum for the "expenses of the Government and the Legislature" is now $\$ 100,000$ for all Provinces having a population under 150,000 , this amount to be increased with the population according to the following table:

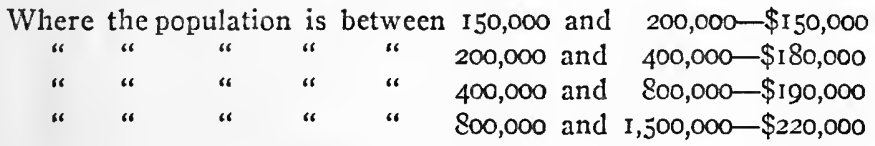

Where the population exceeds $1,500,000 \ldots \ldots \ldots \ldots \ldots \$ 240,000$

The per capita grant is to be at the rate of 80 cents until the population reaches $2,500,000$ when the rate becomes 60 cents per head on the number in excess of this amount. The amounts payable under this provision are calculated on the returns of each decennial census in all the Provinces except Manitoba, Saskatchewan and Alberta, where the payments are based on the returns of each quinquennial census. The Dominion Government still pays to these three Provinces the annual allowance in lieu of lands. Special consideration is also shown to British Columbia and Prince Edward Island in the provision that the grant per capita shall not be less at any time than the amount of the

$$
{ }^{1} 7 \text { Edward VII, c. II. }
$$


corresponding grant payable at the commencement of the Act, notwithstanding any decrease in population. The former Province was also given a special annual grant of $\$ 100,000$ for a period of ten years.

That the Act of 1907 has materially increased the Provincial subsidies may be seen from a comparison of the amounts paid in 1906 with those of the year I9Io, both of which have been calculated on the same population basis. In the former year, Ontario received from the Dominion the sum of $\$ 1,339,287$, and Quebec $\$ 1,086,713$, including subsidy payment and interest. This was increased to $\$ 2$,I28,772 and $\$ 1,781,972$, or a gain of fifty-eight and ninetenths per cent and sixty-three and nine-tenths per cent, respectively. The immediate gain is greater to these two Provinces than to the others, since the per capita grant under the original terms for these Provinces was calculated on the census returns of I86I, while that for the others was to increase with the population until it reached 400,000 souls. ${ }^{1}$ The only Province of this latter class to exceed this maximum was Manitoba, which had a population of $46 \mathrm{r}, 625$ in rgro. The gain to the remaining six is in the increased yearly allowance for the Government, and the future advantage in the provision for making the per capita grant proportionate to population.

It is true that the granting of these subsidies is a departure from the principle of public finance that the revenue should be collected and expended by the same governmental authority. But without these grants to the Provinces, Confederation would not have been possible. The subsidies form a large percentage of the total revenues in each of the Provinces ${ }^{2}$ and other sources are limited. The situa-

1800,000 for Sask. and Alta.

2 Vide tables in "Appendix." 
tion as it existed before the passage of the Act of 1907 is admirably summed up by the Hon. George E. Foster : ${ }^{1}$

The instability of financial conditions as between the Federal and Provincial Governments is still fraught with great possible danger to the success of Confederation, and there is need of all the prudence and firmness possible on the part of the former, and all the wise and accordant co-operation possible on the part of the latter, in order to prevent disastrous results. The Provinces have mostly fixed revenues, pretty well defined and not very elastic. For increase beyond these they can only resort to forms of direct taxation, a proceeding which is unpopular and might be dangerous to party managers. The tendency, therefore, is constantly to press upon the Federal Government for adjustments and additional allowances. The separation of the spending from the providing power tends to induce recklessness in the former and to increase the fierceness of the demand for more. On more than one occasion the demand for better terms and increased subventions has succeeded at Ottawa, and the exigencies of party render such appeals less easy of resistance than they otherwise would be. To spend extravagantly in the Provinces, and for largely. party reasons, with the distant hope that eventually the Dominion Government can be persuaded or forced to come to the rescue, is not an unknown contingency in the history of our party politics, and this contingency constitutes an element of menace to the stability of the Confederation itself.

These dangers, however, have been averted by the new arrangements, which can be altered only by an Imperial act, and which have been accepted as final by the Provinces. For over thirty years the subsidy question had been a bone of contention between the Federal and Provincial Governments, the chief complaint being that these payments were

${ }^{1}$ Loc. cit., p. 310 (1897). 
fixed in amount, or, in the case of certain Provinces, would become fixed after the population had reached a maximum figure. The subsidies had been granted in 1867 " in consideration of the abandonment to the Central Government of the customs and excise duties theretofore collected by the Provinces," 1 and the latter felt that they should receive amounts somewhat proportioned to the increase in the revenue from these two sources and to the greater expenditure made necessary by the growth of population.

Since Confederation, the Province of Quebec had received annually from the Dominion the following amounts:

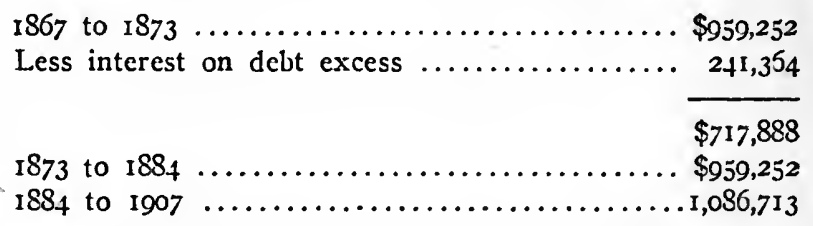

In the first year of Confederation, this Province had received as a subsidy based on population an amount equal to seven and thrce-fotirths per cent of the customs and excise duties collected by the Federal Government, while in 1900 this ratio was only about two and one-third per cent. Its expenditures had increased during the same period from $\$ 1,183,238$ to $\$ 4,707,932$. The specific grant for the expenses of the Government and Legislature was insufficient even in 1868 when the sum of $\$ 213,232$ was spent. $^{2}$

Premier Ross, of Ontario, in a menorandum to the Conference at Quebec in 1902, also showed that the fathers of Confederation had not had an adequate conception of the demands which would be made upon the Provincial Govern-

1 Address of Hon. S. N. Parent, Premier of Quebec, at the Quebec Conference, Dec., I902, printed in Ont. Sessional Papers, vol. xxxv.

$\checkmark$ Ibid. 
ments by a growing population. In the first year of Confederation, the Central Government had paid twenty-four per cent of its revenue from customs and excise duties to the four Provinces then in the Union, while, in I90I, with seven Provinces, this proportion was as low as eleven per cent.

The central authorities, in seven out of the nine Provinces, have confined themselves to taxes on corporations and inheritances and various licenses and fees, leaving to the municipalities those sources of revenue which can be best administered locally. British Columbia has retained for the Provincial Treasury the revenue from taxes on personal property and income, in addition to that derived from the above sources, and, in Prince Edward Island, the Province collects taxes on incomes. Both these Provinces collect a poll tax in the districts lying outside of the municipalities. Some of the Governments, notably those of British Columbia, Prince Edward Island, Alberta and Sas. katchewan, administer the land taxes in unorganized districts of their respective areas. Quebec has a "business license," five per cent of the rental of the premises occupied in Montreal and Quebec and specified amounts in other places, which applies to all manufacturers not incorporated, retail dealers and professional men.

There is overlapping of jurisdiction in connection with the business taxes of both Quebec and Ontario. The Provincial Government of Quebec collects corporation taxes and fees for business licenses from the establishments which pay business taxes to the cities of Montreal and Quebec, and, in the Province of Ontario, public utility companies, banks and others are assessed for the business tax and real estate tax by the localities while they are also required to pay sums to the Province under the Supplementary Revenue Act. The low rates imposed have prevented any out- 
cry against this "double taxation." But, as more stress is laid on corporation taxes as a source of revenue, it will be necessary to require the localities to refrain from taxing the businesses reached by the Provincial authorities, or to permit the corporations to deduct from the amount payable to the Province the taxes which have been paid to the municipalities. 


\section{CHAPTER XII}

\section{Conclusion}

We have seen that the Canadian Provinces, unhampered by constitutional restrictions and political entanglements, have not been slow in introducing experiments aiming to improve the tax system. The personal property tax proving unsatisfactory, recourse was immediately had to a substitute in the form of business assessments, which substitute, though still in the experimental stage, shows undoubted signs of success. On the whole, local taxation in the Canadian Provinces is in a healthful condition.

Very little has been done in Canada in the way of granting to the localities "home rule" or "local option" in matters of taxation. British Columbia and Saskatchewan permit their municipalities to vary the percentage of taxable improvements on real estate, and Manitoba allows its towns and villages to choose between the personal property and the business taxes. Alberta and Saskatchewan villages have the right to limit their tax rate to one on lands exclusive of improvements. Ontario gives its municipalities the power to fix the proportion of the cost of local improvements to be borne by the abutting owners. But the municipalities of all the Provinces must apply to their respective Legislatures for permission to effect any change not covered by these limited privileges.

We find, in the field of Provincial taxation, that, owing to the large percentage of expenditures which are met by the Dominion subsidies, other sources of revenue have not been sufficiently developed. The greatest need in this con167] 
nection is the organization of the taxes on corporations along scientific lines. This will not necessarily result in increased taxation but will enable the taxing authorities to levy the rates equitably and to avoid unjust double taxation. The financial relations of the Provincial Governments to that at Ottawa have been settled, it is to be hoped, by the arrangements of 1907 , and it would be well for the Provinces gradually to work out a system of taxation which will be sufficiently elastic to enable them to meet the demands of an increasing population.

The first step to be taken in this direction is the institution in each Province of a tax commission, whose duty it will be, not only to effect improvements in the administration of the tax system in vogue, but also to devise methods for the improvement of the system itself. It would be the business of such a commission to avoid double taxation by the Provincial and local authorities, and, by co-operation with the other Provinces, to prevent overlapping by the central taxing bodies. Conferences held at regular intervals would be of immense value in the way of suggestions for internal improvements, and relations between the several Provinces could be developed to the point where the administration of the corporation taxes and succession duties would become as efficient as if they were being imposed and collected by one authority throughout the Dominion.

Development along these lines in Provincial taxation and the improvement of the local systems as suggested in the chapter on "Business Assessments" would serve until such time as either a sense of public morality or the perfection of administrative efficiency makes possible the imposition of direct taxes on income. 


\section{APPENDIX}

\section{Statements of Provincial Revenue}

SHOWING THE PROPORTION OF THE TOTAL CONTRIBUTED BY EACH OF THE PRINCIPAL SOURCES

\section{ONTARIO \\ (Year ending October 3I, IgII.)}

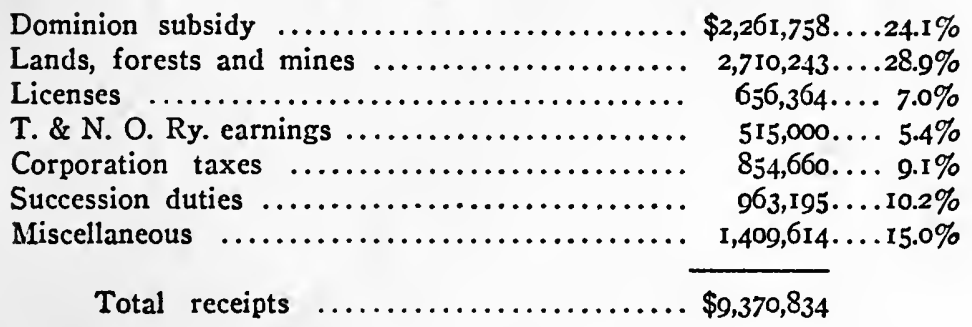

\section{QUEBEC}

(Year ending June 30 , rgIr.)

Dominion subsidy $\$ 1,761,473 \ldots 25.0 \%$

Lands, forests, mines and fisheries ............ $1,38 \mathrm{r}, 380 \ldots \ldots 19.6 \%$

Licenses (hotels, shops, etc.) $\ldots \ldots \ldots \ldots \ldots \ldots \ldots . \quad 938,664 \ldots \ldots 13.3 \%$

Taxes on commercial corporations ............. $712,118 \ldots \ldots 10.1 \%$

Succession duties $\ldots \ldots \ldots \ldots \ldots \ldots \ldots \ldots \ldots \ldots \ldots, \quad \mathrm{r}, 072,027 \ldots \ldots 15.2 \%$

Miscellaneous $\ldots \ldots \ldots \ldots \ldots \ldots \ldots \ldots \ldots \ldots \ldots, \quad \mathrm{r}, 167,083 \ldots \ldots 16.5 \%$

Total receipts .................... \$7,032,745

NEW BRUNSWICK

(Year ending October 3I, IgII.)

Dominion subsidy $\ldots \ldots \ldots \ldots \ldots \ldots \ldots \ldots \ldots \ldots \ldots, \$ 621,361 \ldots . .46 .1 \%$

Territorial revenue ........................ $528,439 \ldots .39 .2 \%$

Fees and licenses $\ldots \ldots \ldots \ldots \ldots \ldots \ldots \ldots \ldots . .6 .61,479 \ldots .60 \%$

Taxes on incorporated companies ............. $48,278 \ldots .3 .5 \%$

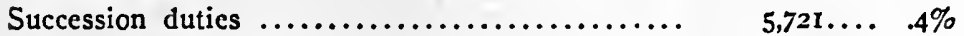

Miscellaneous $\ldots \ldots \ldots \ldots \ldots \ldots \ldots \ldots \ldots \ldots \ldots .6 .61,799 \ldots . .5 \%$

Total receipts ..................... \$1,347,077

169] $\quad 169$ 


\section{NOVA SCOTIA}

\section{(Year ending September 30, 1911.)}

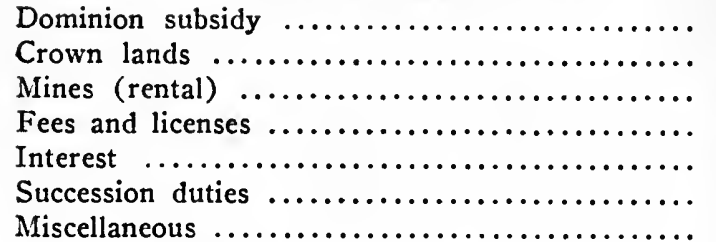

$\$ 610,460 \ldots . .37 .5 \%$

$13,109 \ldots . . .8 \%$

$647,606 \ldots 39.8 \%$

$32,649 \ldots 2.0 \%$

$165,573 \ldots .10 .1 \%$

$4 \mathrm{I}, 649 \ldots 2.5 \%$

$114,607 \ldots . .7 .0 \%$

Total receipts

$\$ 1,625,653$

\section{MANITOBA}

(Year ending December 3I, 1911.)

Dominion subsidy $\$ 1,021,794 \ldots 29.5 \%$

Provincial lands $575,626 \ldots .16 .6 \%$

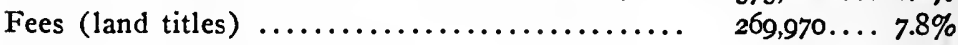

Fees (liquor licenses) ................... II $2,427 \ldots 3.2 \%$

Profits of telephone systems ................ $318,309 \ldots .9 .1 \%$

Taxes on corporations and railways ........... $237,724 \ldots 6.8 \%$

Succession duties..$\ldots \ldots \ldots \ldots \ldots \ldots \ldots \ldots \ldots \ldots$.

Miscellaneous

$165,860 \ldots 4.8 \%$

$752,480 \ldots 21.7 \%$

Total receipts

$3,454,190$

\section{BRITISH COLUMBIA}

(Year ending March 31, I9ro.)

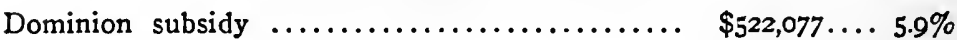

Lands, etc. . ........................ $5,258,290 \ldots .59 .6 \% \%^{1}$

Chinese restriction (Dom., Stat., 1884) $\ldots \ldots \ldots \ldots .6356,200 \ldots . .6 \%$

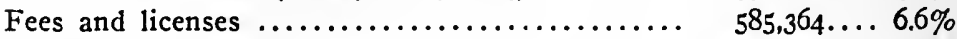

Succession duties ........................ 108,495... $1.2 \%$

Revenue tax (poll) $\ldots \ldots \ldots \ldots \ldots \ldots \ldots \ldots \ldots \ldots .260,682 \ldots \ldots 2.9 \%$

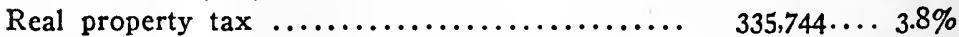

Personal property tax $\ldots \ldots \ldots \ldots \ldots \ldots \ldots \ldots . .161,693 \ldots . .1 .8 \%$

Wild land tax (including coal and timber lands).. $\quad 250,905 \ldots 2.8 \%$

Income tax (including tax on corporations) ...... 190,984... $2.1 \%$

Mineral and coal taxes (including royalty) ..... $325,332 \ldots 3.6 \%$

Miscellaneous ............................ $462,830 \ldots .5 .2 \%$

Total receipts $\ldots \ldots \ldots \ldots \ldots \ldots \ldots \ldots \ldots \$ \$, 8,818,596$

1 Revenue from land sales alone was $\$ 2,618,188$, which exceeds the receipts from this source in 1909 by over two million dollars. 


\section{SASKATCHEWAN}

(Year ending February 28, 1911.)

Dominion subsidy

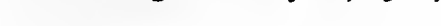

Fees (land titles)

\begin{tabular}{|c|}
\hline $1,375,938 \ldots 51.7 \%$ \\
\hline $132,956 \ldots 5.0 \%$ \\
\hline $214,245 \ldots 8.0 \%$ \\
\hline $128,940 \ldots 4.8 \%$ \\
\hline $115,083 \ldots 4.3 \%$ \\
\hline $39,615 \ldots$... $1.5 \%$ \\
\hline $381,965 \ldots . .14 .3 \%$ \\
\hline
\end{tabular}

Total receipts

$\$ 2,656,627$

\section{ALBERTA}

(Year ending December 31, 1909.)

Dominion subsidy

$\$ 1,340,195 \ldots 51.4 \%$

Fees (land titles)

$134,746 \ldots 5.1 \%$

Fees (liquor licenses)

$76,672 \ldots 2.9 \%$

Dairy Department

$260,959 \ldots . .10 .0 \%$

Corporation and railway taxes

Succession duties

$109,357 \ldots 4.2 \%$

Miscellaneous

$10,336 \ldots . .4 \%$

$673,336 \ldots 25.8 \%$

Total receipts

$\$ 2,605,601$

\section{PRINCE EDWARD ISLAND}

(Year.ending September 30, I910.)

Dominion subsidy $\$ 272,182 \ldots 72.5 \%$

Fees and licenses

II, $900 \ldots 3.1 \%$

Taxes on corporations $\ldots \ldots \ldots \ldots \ldots \ldots \ldots \ldots$

$15,475 \ldots 4.1 \%$

Income $\operatorname{tax}$

I $1,372 \ldots 3.0 \%$

Land tax

$35,785 \ldots 9.5 \%$

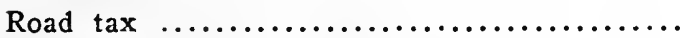

Succession duties

$14,163 \ldots 3.7 \%$

$4,835 \ldots . .2 \%$

Miscellaneous

$9,439 \ldots 2.5 \%$

Total receipts

$\$ 375,15$ I 





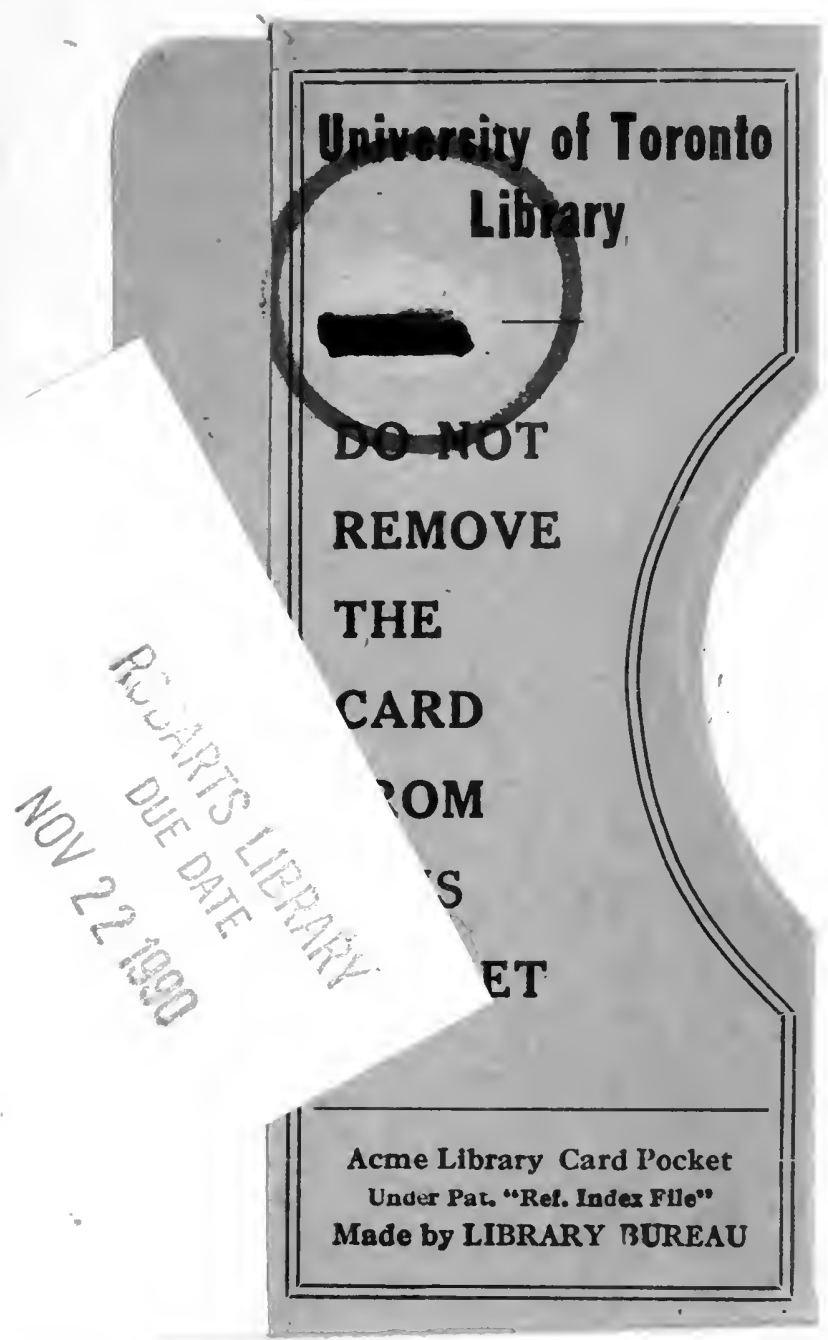


